\title{
WATER LEVELS IN THE YUCCA MOUNTAIN AREA, NEVADA, 1994
}

$$
\text { USGS/OFR-.95-757 }
$$

by Robert P. Graves, Patrick Tucci, and Robert L. Goemaat

U.S. GEOLOGICAL SURVEY

Open-File Report 95-757

Prepared in cooperation with the

NEVADA OPERATIONS OFFICE,

U.S. DEPARTMENT OF ENERGY, under

Interagency Agreement DE-A108-92NV10874

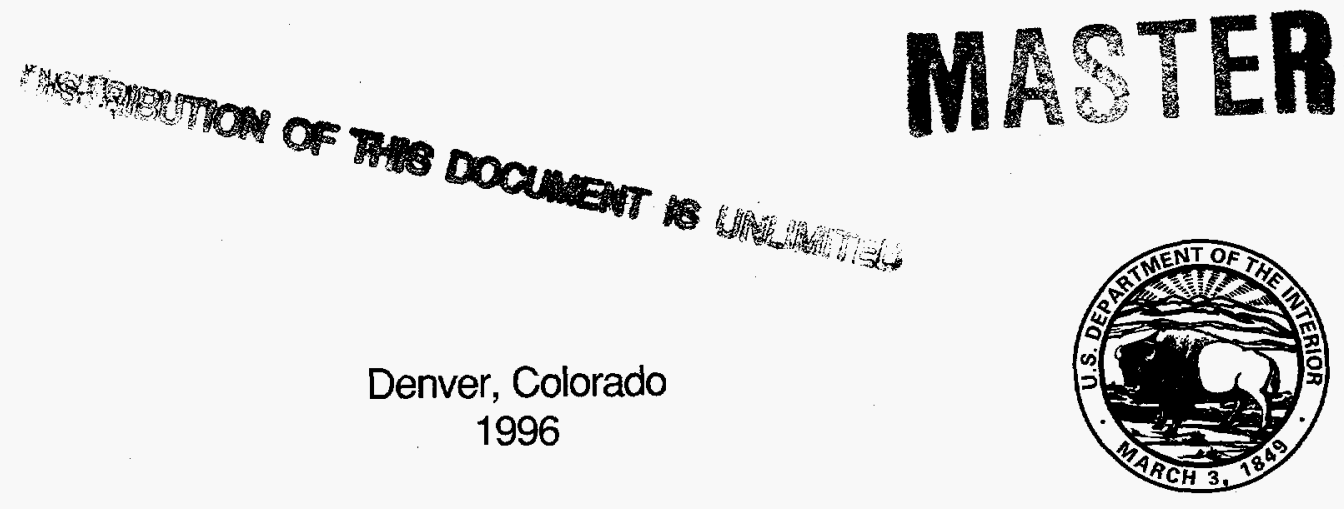




\title{
U.S. DEPARTMENT OF THE INTERIOR BRUCE BABBITT, Secretary
}

\author{
U.S. GEOLOGICAL SURVEY \\ Gordon P. Eaton, Director
}

The use of firm, trade, and brand names in this report is for identification purposes only and does not constitute endorsement by the U.S. Geological Survey.

For additional information write to:

Chief, Hydrologic Investigations Program

Yucca Mountain Project Branch

U.S. Geological Survey

Box 25046, Mail Stop 421

Denver Federal Center

Denver, CO 80225-0046
Copies of this report can be purchased from:

U.S. Geological Survey

Branch of Information Services

Box 25286

Denver, CO 80225-0286 


\section{DISCLAIMER}

This report was prepared as an account of work sponsored by an agency of the United States Government. Neither the United States Government nor any agency thereof, nor any of their employees, make any warranty, express or implied, or assumes any legal liability or responsibility for the accuracy, completeness, or usefulness of any information, apparatus, product, or process disclosed, or represents that its use would not infringe privately owned rights. Reference herein to any specific commercial product, process, or service by trade name, trademark, manufacturer, or otherwise does not necessarily constitute or imply its endorsement, recommendation, or favoring by the United States Government or any agency thereof. The views and opinions of authors expressed herein do not necessarily state or reflect those of the United States Government or any agency thereof. 


\section{DISCLAIMER}

Portions of this document may be illegible in electronic image products. Images are produced from the best available original document. 


\section{CONTENTS}

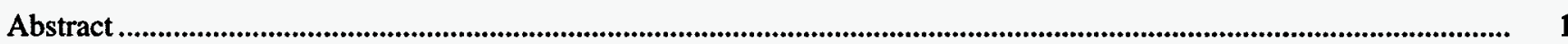

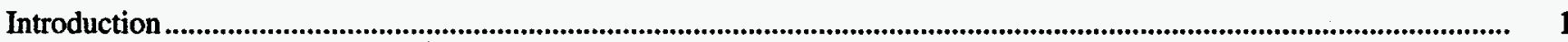

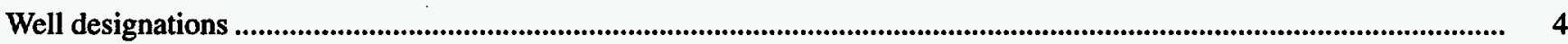

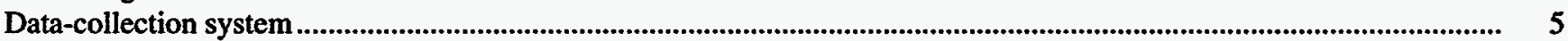

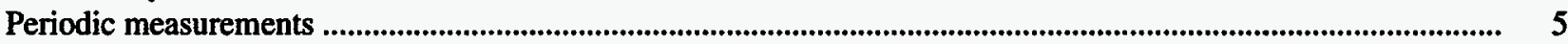

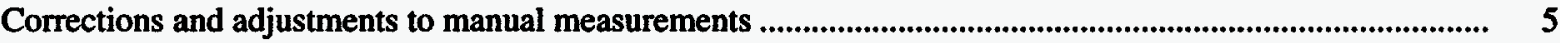

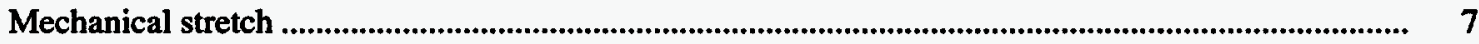

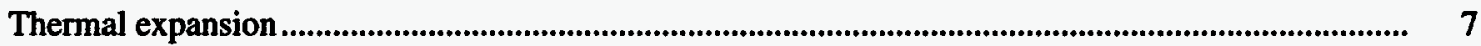

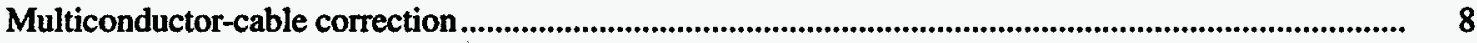

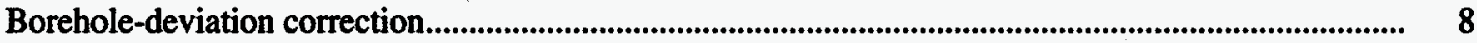

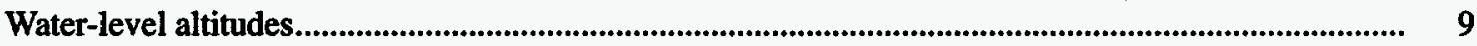

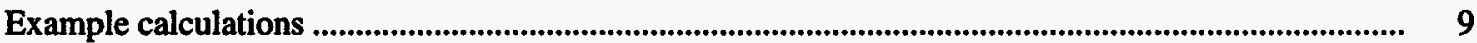

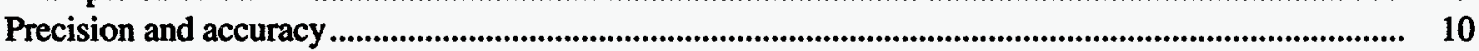

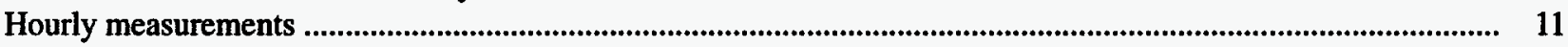

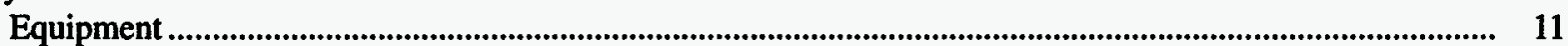

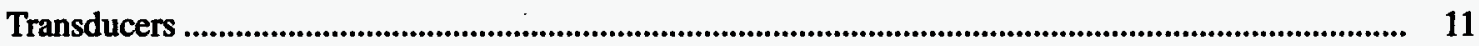

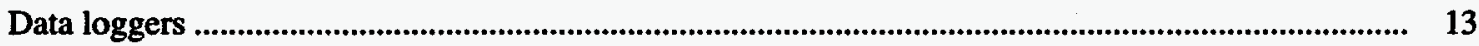

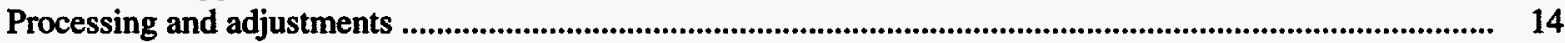

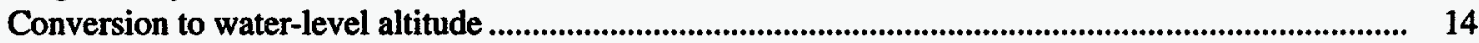

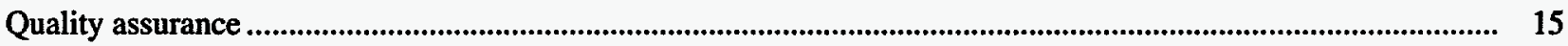

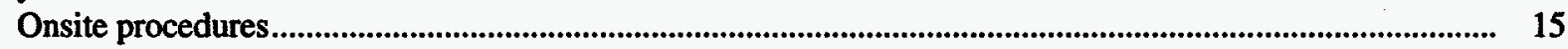

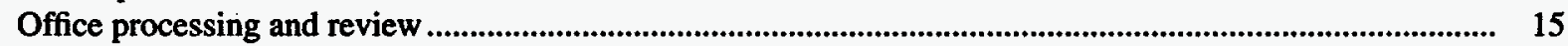

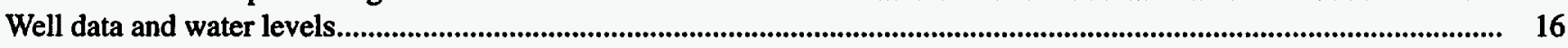

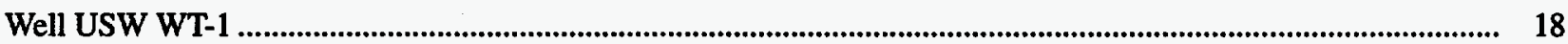

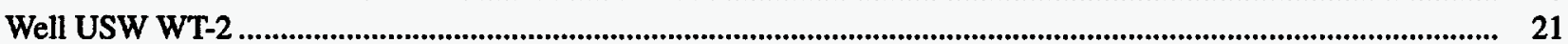

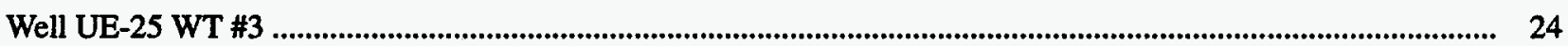

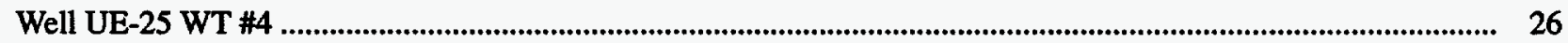

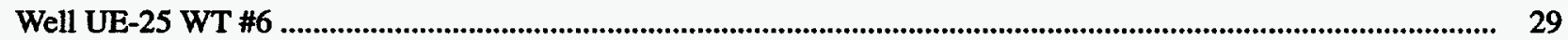

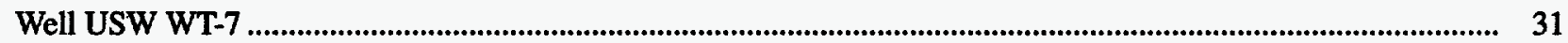

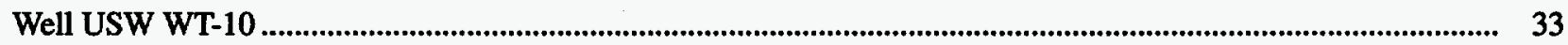

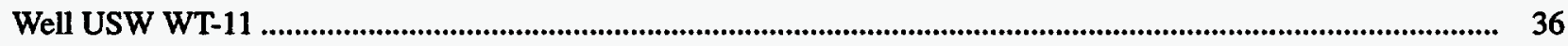

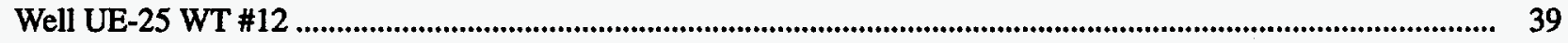

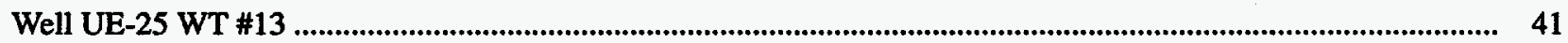

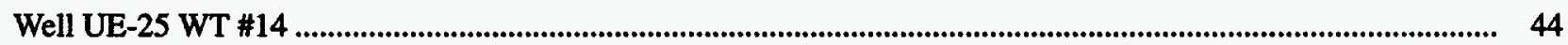

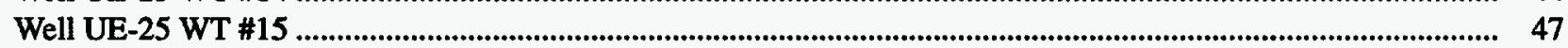

Well UE-25 WT \#16

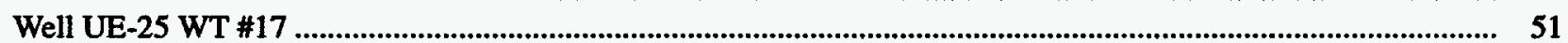

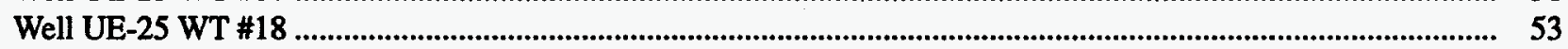

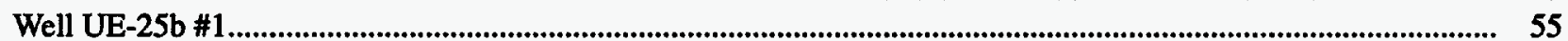

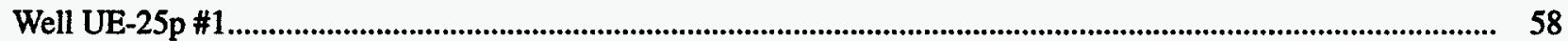

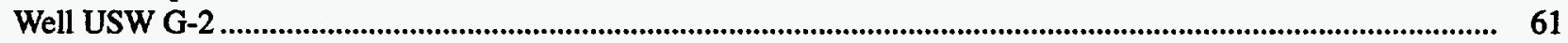

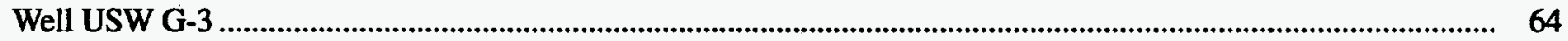

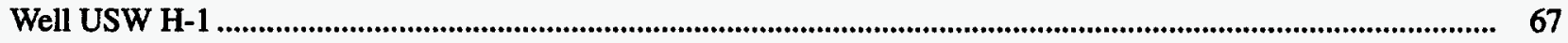

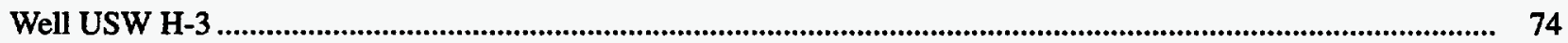

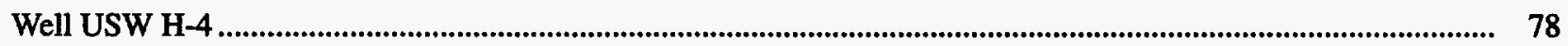

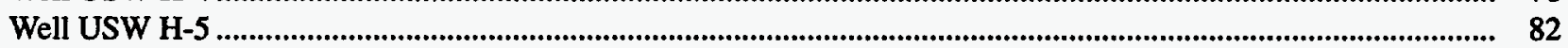

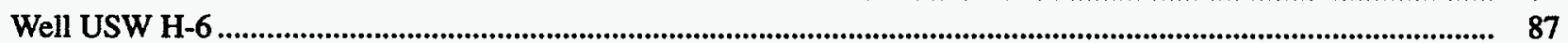




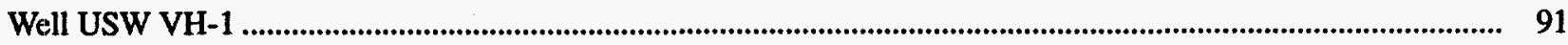

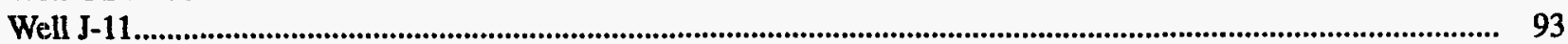

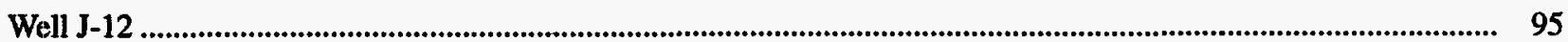

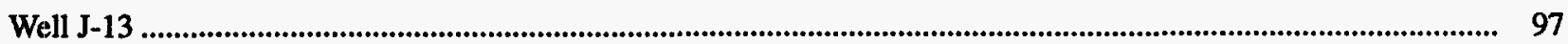

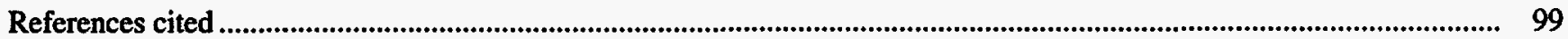

\section{FIGURES}

1. Map showing location of Yucca Mountain area and location of wells................................................................... 2

2-37. Hydrographs showing water-level altitudes, 1994, for:

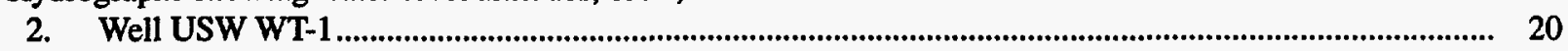

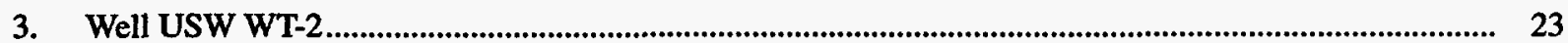

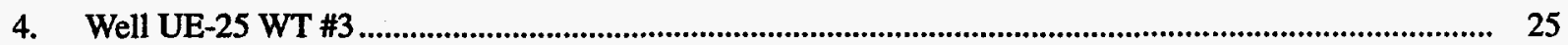

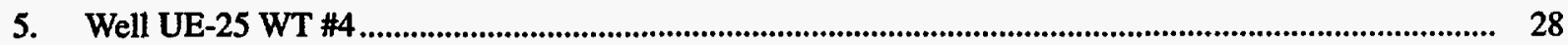

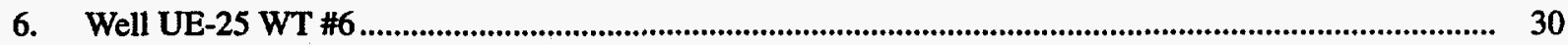

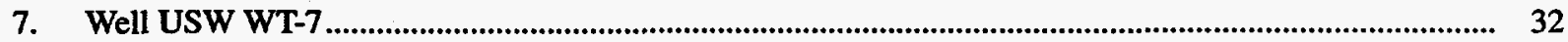

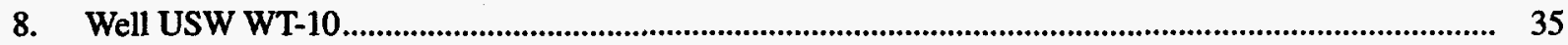

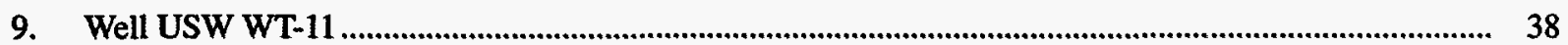

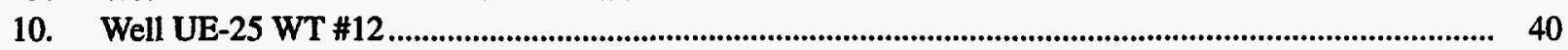

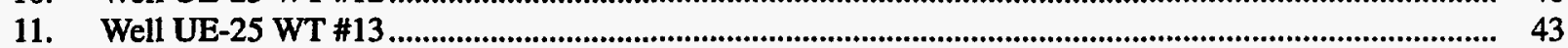

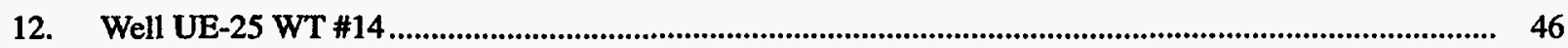

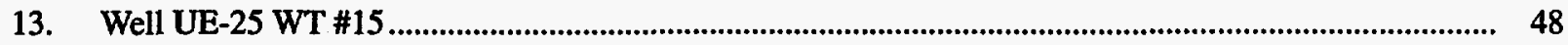

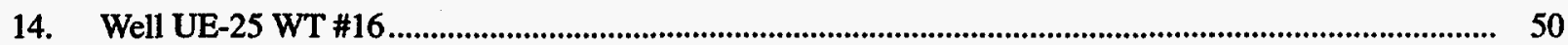

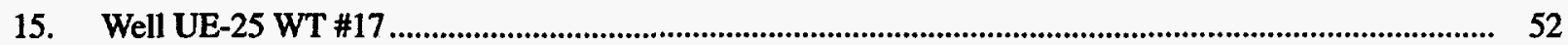

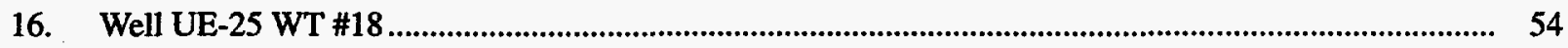

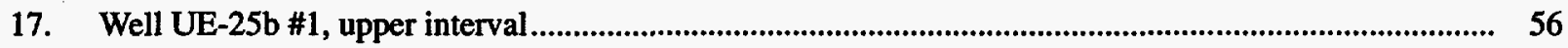

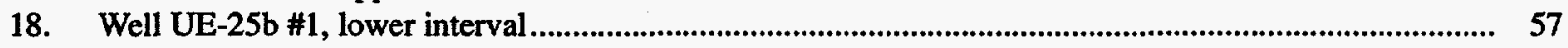

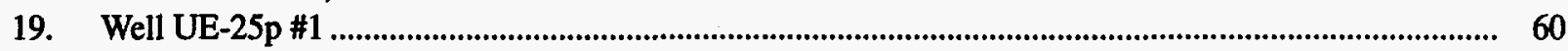

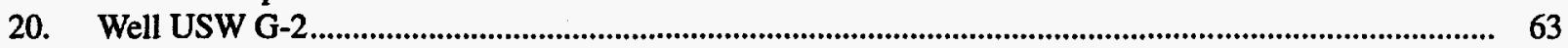

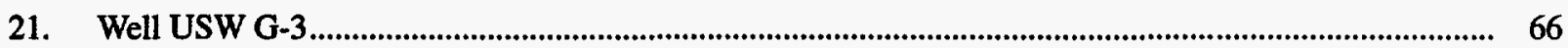

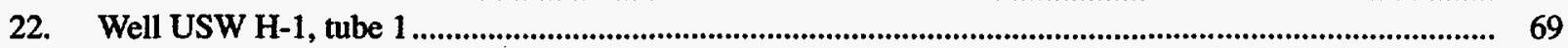

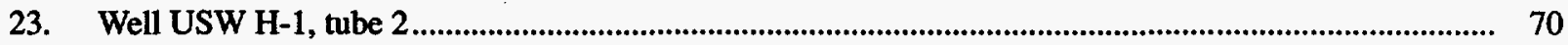

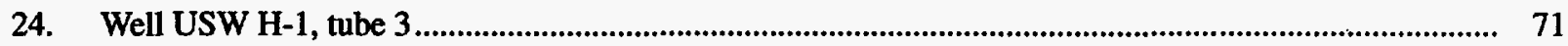

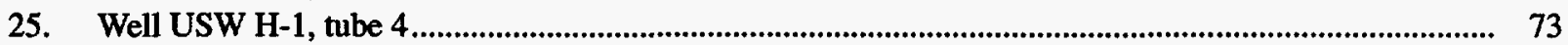

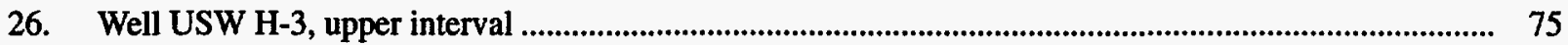

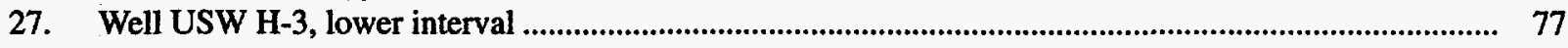

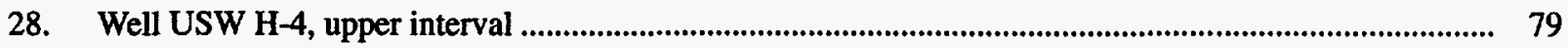

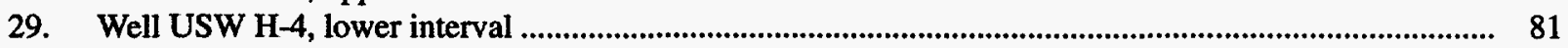

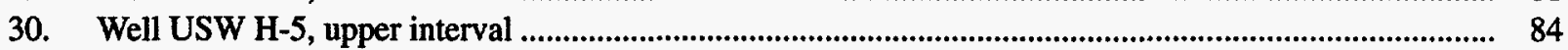

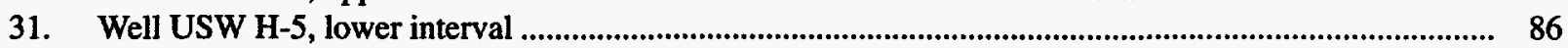

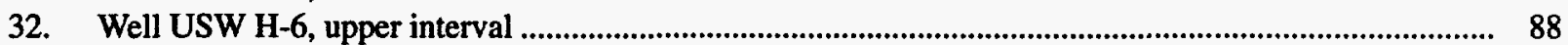

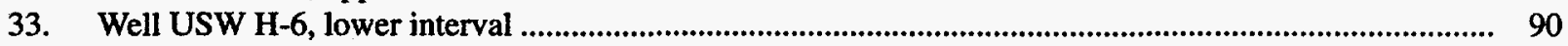

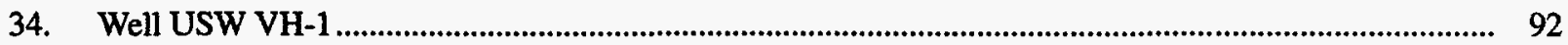

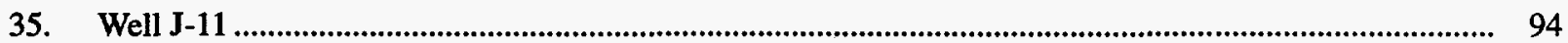

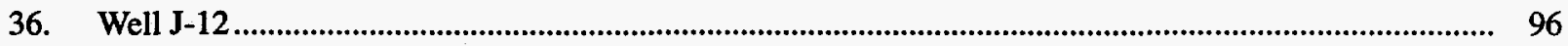

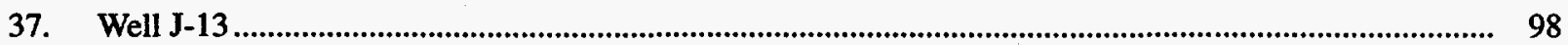




\section{TABLES}

1. Summary of wells monitored for water levels, 1994

2. Corrections applicable to steel tapes used for measuring water levels, 1994, in the vicinity of Yucca Mountain .

3. Mechanical stretch and thermal expansion equation variable values for steel tapes used in the vicinity of Yucca Mountain

4-24. Mean monthly water-level altitudes, 1994, for:

4. Well USW WT-1

5. Well USW WT-2.

6. Well UE-25 WT \#3

7. Well UE-25 WT \#4

8. Well USW WT-10

9. Well USW WT-11.

10. Well UE-25 WT \#13.

11. Well UE-25 WT \#14

12. Well UE-25p \#1

13. Well USW G-2

14. Well USW G-3

15. Well USW H-1, tube 3

16. Well USW H-1, tube 4 .

17. Well USW H-3, upper interval

18. Well USW H-3, lower interval

19. Well USW H-4, upper interval

20. Well USW H-4, lower interval

21. Well USW H-5, upper interval

22. Well USW H-5, lower interval

23. Well USW H-6, upper interval

24. Well USW H-6, lower interval

\section{CONVERSION FACTORS AND VERTICAL DATUM}

\begin{tabular}{rll}
\hline Multiply & By & To obtain \\
cubic meter $\left(\mathrm{m}^{3}\right)$ & & gallon \\
kilometer $(\mathrm{km})$ & 264.2 & mile \\
$\operatorname{liter}(\mathrm{L})$ & 0.6214 & cubic foot \\
meter $(\mathrm{m})$ & 0.03531 & foot \\
millimeter $(\mathrm{mm})$ & 0.03937 & kilogram per square meter \\
pound per square inch $(\mathrm{psi})$ & 703.1 & square mile \\
square kilometer $\left(\mathrm{km}^{2}\right)$ & 0.3861 & \\
\hline
\end{tabular}

Sea level: In this report "sea level" refers to the National Geodetic Vertical Datum of 1929 (NGVD of 1929)-a geodetic datum derived from a general adjustment of the first-order level nets of both the United States and Canada, formerly called Sea Level Datum of 1929. 


\title{
Water Levels in the Yucca Mountain Area, Nevada, 1994
}

\author{
ByRobert P. Graves, Patrick Tucci, and Robert L. Goemaat
}

\section{Abstract}

Water levels were monitored in 28 wells in the Yucca Mountain area, Nevada, during 1994. Twelve wells representing 13 intervals were monitored periodically, generally on a monthly basis, 6 wells representing 10 intervals were monitored hourly, and 10 wells representing 13 intervals were monitored both periodically and hourly. All wells monitor water levels in Tertiary volcanic rocks, except one, that monitors water levels in Paleozoic carbonate rocks. Water levels were measured using calibrated steel tapes, a multiconductor cable unit, and pressure transducers.

Water-level altitudes in the Tertiary volcanic rocks ranged from about 728 to about 1,034 meters above sea level during 1994. The mean-annual water-level altitude in the well monitoring the Paleozoic carbonate rocks was about 753 meters above sea level during 1994 . Water levels were only an average of about 0.01 meters lower than 1993 water levels. All data were acquired in accordance with a quality-assurance program to support the reliability of the data.

\section{INTRODUCTION}

The Yucca Mountain area is being evaluated by the U.S. Department of Energy for suitability to store high-level nuclear waste in a mined, underground repository. A $150 \mathrm{~km}^{2}$ area located about $150 \mathrm{~km}$ northwest of Las Vegas in southern Nevada is being studied extensively (fig. 1). Water levels in selected wells have been measured periodically since 1981, and have been measured on an hourly or more frequent basis since 1983, to gain a better understanding of the ground-water flow system in the area. Water levels will be used to determine the direction and rate of ground-water flow, and to estimate hydraulic parameters of the flow system. In the Yucca Mountain area, the water table is in air-fall and ash-flow tuffs of Tertiary age. Saturated carbonate rocks of Paleozoic age underlie the Tertiary volcanic rocks. The geology and description of stratigraphic units in the study area was originally defined by Winograd and Thordarson (1975), Byers and others (1976), Carr and others (1986), and Carr (1988). The nomenclature for stratigraphic units in the study area has recently been revised by Sawyer and others, (1994). This report uses the new revised geologic nomenclature terminology.

This report describes the equipment and methods used to collect and process water-level data, presents the data collected, and lists water-level altitudes for a network of 28 wells (fig. 1, table 1). The network has evolved into one that, in 1994, included 12 wells representing 13 intervals that were monitored periodically, generally on a monthly basis, 6 wells representing 10 intervals that were monitored hourly, and 10 wells representing 13 intervals that were monitored both periodically and hourly. Continuous water-level and fluid-pressure data were also collected at wells USW H-5 and USW H-6, using analogchart recorders to allow monitoring of fluctuations caused by earthquakes; however, these continuous data are not included in this report. All wells monitor water levels in the various Tertiary volcanic rocks that underlie the Yucca Mountain area except well UE-25p \#1, which monitors water levels in the Paleozoic carbonate rocks that underlie the volcanic rocks.

Water levels are measured periodically, generally monthly, using calibrated steel tapes or a multiconductor cable. Water levels are also monitored hourly using pressure transducers and electronic data loggers. The transducer/data-logger systems are calibrated by recording transducer output at known depths of submergence. Water-level measurements are made to obtain depth-to-water information during 


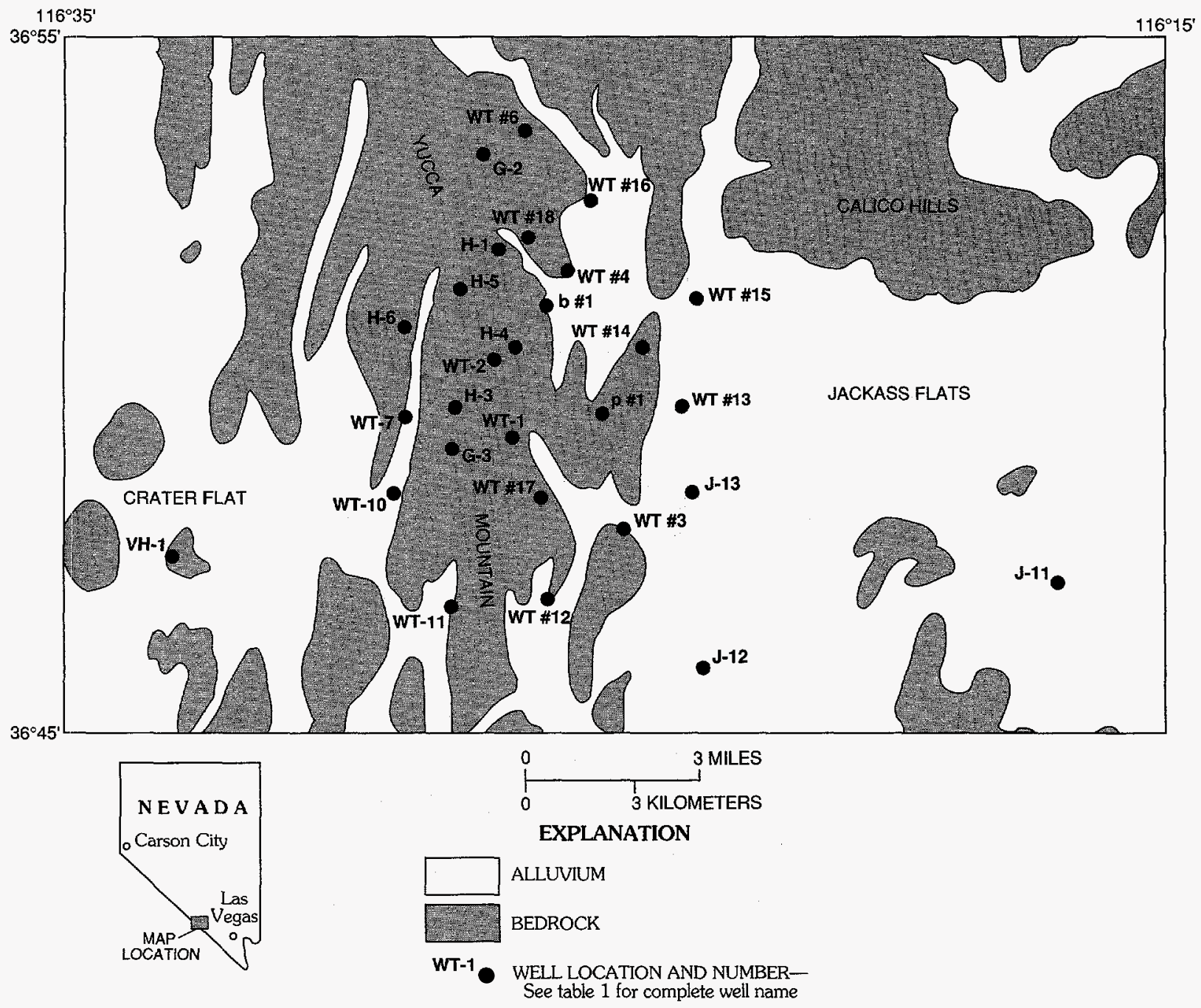

Figure 1. Location of Yucca Mountain area and location of wells. 
Table 1. Summary of wells monitored for water levels, 1994

[p \& h, well measured periodically and hourly during 1994; p, well measured periodically during 1994; h, well measured hourly during 1994; ---, data not available]

\begin{tabular}{|c|c|c|c|c|c|c|}
\hline \multirow[b]{2}{*}{ Well name } & \multirow[b]{2}{*}{$\begin{array}{l}\text { Drillod depth } \\
\text { (meters) }\end{array}$} & \multirow[b]{2}{*}{$\begin{array}{l}\text { Depth below land } \\
\text { surface of bottom } \\
\text { of monitoring tube } \\
\text { (meters) }\end{array}$} & \multirow[b]{2}{*}{$\begin{array}{l}\text { Date completed } \\
\text { (month/year) }\end{array}$} & \multicolumn{3}{|c|}{ Water lovel } \\
\hline & & & & $\begin{array}{c}\text { Approximate } \\
\text { mean-annual, } \\
\text { 1994, depth below } \\
\text { reference point } \\
\text { (meters) }\end{array}$ & $\begin{array}{l}\text { Approximate } \\
\text { mean-annual, } \\
\text { 1994, altitude } \\
\text { (meters) }\end{array}$ & $\begin{array}{l}\text { Frequency } \\
\text { monitored }\end{array}$ \\
\hline USWWT-1 & 515 & 507.5 & $5 / 83$ & 471 & 730 & $\mathrm{p \& h}$ \\
\hline USW WT-2 & 628 & 622.0 & $7 / 83$ & 570 & 731 & $\mathrm{p} \& \mathrm{~h}$ \\
\hline UE-25 WT \#3 & 348 & 343.0 & $5 / 83$ & 300 & 730 & $\mathbf{h}$ \\
\hline UE-25 WT \#4 & 482 & 477.6 & $6 / 83$ & 438 & 731 & $\mathrm{p} \& \mathrm{~h}$ \\
\hline UE-25 WT \#6 & 383 & 372.0 & $6 / 83$ & 281 & 1,034 & p \\
\hline USW WT-7 & 491 & 481.3 & $7 / 83$ & 421 & 776 & $\mathrm{p}$ \\
\hline USW WT-10 & 431 & 402.6 & $8 / 83$ & 347 & 776 & $\mathrm{p} \& \mathrm{~h}$ \\
\hline USW WT-11 & 441 & 416.0 & $8 / 83$ & 363 & 731 & $\mathrm{p} \& \mathrm{~h}$ \\
\hline UE-25 WT \#12 & 399 & 388.9 & $8 / 83$ & 346 & 729 & $\mathrm{p}$ \\
\hline UE-25 WT \#13 & 354 & 346.0 & $7 / 83$ & 304 & 729 & $\mathrm{p} \& \mathrm{~h}$ \\
\hline UE-25 WT \#14 & 399 & 397.2 & 9/83 & 346 & 730 & $\mathrm{p} \& \mathrm{~h}$ \\
\hline UE-25 WT \#15 & 415 & 406.9 & $11 / 83$ & 354 & 729 & p \\
\hline UE-25 WT \#16 & 521 & 514.0 & $11 / 83$ & 473 & 738 & $\mathrm{p}$ \\
\hline UE-25 WT \#17 & 443 & 419.4 & $10 / 83$ & 394 & 730 & $\mathbf{p}$ \\
\hline UE-25 WT \#18 & 623 & 609.0 & $5 / 84$ & 605 & 731 & $\mathrm{p}$ \\
\hline UE-25b \#1 & 1,220 & -.- & 9/81 & -- & $\cdots$ & -- \\
\hline upper interval & -. & 488.0 & $\cdots$ & 470 & 731 & $\mathrm{p}$ \\
\hline lower interval & -- & $1,199.0$ & -.. & 471 & 730 & $\mathbf{p}$ \\
\hline UE-25p \#1 & 1,805 & $\mathrm{i}_{418.0}$ & $5 / 83$ & 361 & 753 & h \\
\hline USW G-2 & 1,831 & (2) & $10 / 81$ & 534 & 1,020 & $\mathrm{p} \& \mathrm{~h}$ \\
\hline USW G-3 & 1,533 & 792.0 & $3 / 82$ & 749 & 731 & p \& h \\
\hline USW H-1 & 1,829 & --- & $1 / 81$ & 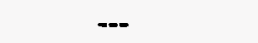 & -- & -- \\
\hline Tube 1 & -- & $1,806.0$ & --. & 517 & 786 & $\mathbf{p}$ \\
\hline Tube 2 & -- & $1,115.0$ & $\ldots$ & 567 & 736 & $\mathbf{p}$ \\
\hline Tube 3 & --. & 741.0 & --- & 572 & 731 & h \\
\hline Tube 4 & --- & 640.0 & -- & 572 & 731 & $\mathbf{h}$ \\
\hline USW H-3 & 1,219 & --- & $3 / 82$ & --- & -- & -- \\
\hline upper interval & --- & 762.0 & --- & 752 & 731 & $\mathbf{h}$ \\
\hline lower interval & --- & $1,114.0$ & -.. & 725 & 758 & $\mathbf{h}$ \\
\hline USW H-4 & 1,219 & -- & $6 / 82$ & --- & --- & -- \\
\hline upper interval & --- & 525.0 & --- & 519 & 730 & $\mathbf{h}$ \\
\hline lower interval & -- & $1,188.0$ & --- & 519 & 730 & $\mathbf{h}$ \\
\hline USW H-5 & 1,219 & --- & $8 / 82$ & -- & -- & -- \\
\hline upper interval & --. & 709.0 & -- & 704 & 775 & $\mathbf{h}$ \\
\hline lower interval & -- & 846.0 & -- & 703 & 776 & h \\
\hline USW H-6 & 1,220 & --- & $10 / 82$ & -- & --. & --- \\
\hline upper interval & -- & 533.0 & -- & 526 & 776 & $\mathbf{h}$ \\
\hline lower interval & -- & 752.0 & $-\ldots$ & 526 & 776 & h \\
\hline USW VH-1 & 762 & 205.4 & $2 / 81$ & 184 & 779 & $\mathrm{p}$ \\
\hline $\mathrm{J}-11$ & 405 & (3) & $7 / 57$ & 317 & 732 & $\mathrm{p}$ \\
\hline $\mathrm{J}-12$ & $\mathbf{4}_{347}$ & -- & $8 / 68$ & 227 & 728 & $\mathrm{p}$ \\
\hline $\mathrm{J}-13$ & 1,063 & -- & $1 / 63$ & 283 & 728 & p \\
\hline
\end{tabular}

${ }^{1}$ Well is constructed so that the hydraulic head in the Paleozoic carbonate rocks located 1,244 meters below land surface is monitored.

${ }^{2}$ Well measured through open casing. Well is open hole from 242 meters below land surface to bottom of well.

${ }^{3}$ Well measured through open casing. Well is cased to bottom of well. Casing is perforated from 328.3 to 334.4 meters below land surface and from 379.2 to 396.2 meters below land surface.

${ }^{4}$ Original drilled depth 271 meters in 1957; well deepened to present depth in 1968. 
calibration using transducers, calibrated steel tapes, or multiconductor cables. The manual waterlevel measurements are adjusted for thermal expansion, mechanical stretch, equipment calibration, and borehole deviation from vertical. Hourly water-level altitudes are computed based on the calibration, the manual water-level measurement, and the surveyed altitude of the reference point.

This report is a companion and supplement to other reports that present water levels in the Yucca Mountain area (Robison and others, 1988; Gemmell, 1990; O'Brien, 1991; Boucher, 1994; Luckey and others, 1993; Lobmeyer and others, 1995; Tucci, O'Brien, and Burkhardt, 1996; O'Brien and others, 1995; Tucci, Goemaat, and Burkhardt, 1996). Robison and others (1988) describe the details of how the manual water-level measurements were made and corrected to compute the water-level altitude.

The water-level data were obtained as part of the Yucca Mountain Project of the U.S. Department of Energy. The Yucca Mountain Project is described by a Site Characterization Plan (U.S. Department of Energy, 1988). The data in this study were collected by the U.S. Geological Survey and its contractors in cooperation with the U.S. Department of Energy under Interagency Agreement DE-AI08-92NV10874.

\section{WELL DESIGNATIONS}

Each well used in the study of the Yucca Mountain area has a unique name or number. Wells on the Nevada Test Site (NTS) use an NTS designation, whereas wells off the NTS use a slightly different designation. Wells on the NTS begin with UE (for Underground Exploratory), followed by the NTS area number (always 25 in this report). This designation-UE-25-commonly is followed by one or more letters signifying the purpose of the well or simply by a sequential letter, followed by a sequence number. Wells off the NTS begin with the letters USW (for Underground, Southern Nevada, Waste). The designation-USW-is followed by one or more letters signifying the primary purpose of the well followed by a sequence number. The letters signifying purpose that are used in this report are $\mathrm{G}$ (collection of geologic data), $\mathrm{H}$ (collection of hydrologic data), $\mathrm{p}$ (collection of data on rocks of Paleozoic age), VH (collection of hydrologic and geologic data of volcanic rocks) and WT (collection of water-table data). The only wells not using this designation system and referred to in this report are wells $\mathrm{J}-11, \mathrm{~J}-12$, and $\mathrm{J}-13$, which were drilled as watersupply wells.

Nevada State Coordinates are used to identify the location of wells cited in this report. These coordinates are for the central zone of Nevada and are based on a Transverse Mercator projection. The origin of this projection for the central zone of Nevada is latitude $34^{\circ} 45^{\prime} \mathrm{N}$, and the central meridian is at longitude $116^{\circ} 40^{\prime} \mathrm{W}$. The Nevada State Coordinates are in meters north of the baseline and in meters, plus 152,400 east of the central meridian. The Nevada State Coordinate locations for the wells were determined by Holmes \& Narver, Inc., contractor to the U.S. Department of Energy for surveying at the NTS and Yucca Mountain area. Latitude and longitude values of the wells were calculated from the Nevada State Coordinates.

The Site ID number is used for unique identification of the well in the U.S. Geological Survey's databases. The Site ID is generated by combining the original designations of the latitude and longitude with a two-digit sequence number. The Site ID is for convenience of identification only and should not be used as an actual location number because the original designations of latitude and longitude may be inaccurate. Even if original values of the latitude and longitude are revised later, the Site ID for the well is not changed. If more than one well exists within the 1 -second rectangle of latitude and longitude, the two-digit sequence number is used to ensure uniqueness of the Site ID.

Some wells within the water-level network have had packers or piezometers installed so the water level at discrete intervals can be measured. In these instances, before the packers or piezometers were installed, the well was assigned one Site ID (generally with a sequence number of 01), and prior to 1990, each depth interval was assigned its own unique Site ID by incrementing the 
sequence number. Hence, some wells within the network have several Site ID's. However, since 1990, the water-level data are generally stored in the National Water Information System (NWIS) data base under the Site ID with sequence number 01. Exceptions are wells USW H-5 and UE-25p \#1, which use the Site ID with sequence number 02. For those wells that have more than one zone monitored, the water levels are kept distinct in NWIS with the use of data descriptors which define each unique zone.

\section{DATA-COLLECTION SYSTEM}

Water-level data are collected at Yucca Mountain by means of manual periodic measurements and by use of pressure transducers that are monitored hourly by data loggers. Periodic measurements are discussed first, followed by a discussion of the pressure-transducer system. All water-level measurements are subject to various corrections, and these corrections are also discussed.

\section{Periodic Measurements}

Periodic, manual, water-level measurements at wells require visits by trained personnel, who perform specific operations and record the results. Operational plans for 1994 called for measurements about once per month at each well. Measurement frequency, however, did vary; water levels in some wells were measured less frequently because of factors such as temporary shortage of trained personnel, breakdown of equipment, or well-site inaccessibility due to road washouts. Manual water-level measurements also are made at hourly monitored wells at times of calibration or replacement of defective pressure transducers.

Periodic measurements during 1994 primarily were made using "Chain \#3", which is a specially constructed reeled steel tape that is $7.9-\mathrm{mm}$ wide and $792-\mathrm{m}$ long. Twenty measurements were made in wells UE-25 WT \#17, UE-25b \#1, and USW G-3 using a multiconductor-cable unit. One measurement each was made at well USW VH-1, well USW H-3, and well J-11 using the " 2,800 -ft reference steel tape", which is a reeled steel tape that is $6.4-\mathrm{mm}$ wide and $853-\mathrm{m}$ long. Detailed descriptions of steel tapes and the multiconductor cable unit used to measure water levels for this study are given by O'Brien (1991), and are not repeated here.

\section{Corrections and Adjustments to Manual Measurements}

Various factors affect the accuracy of manual water-level measurements and are considered in the process of determining an accurate depth below land surface and the water-level altitude. All measurements in this report have been corrected to obtain the most accurate water-level altitudes. The correction factors applied to steel-tape measurements for each well are summarized in table 2 .

Corrections made for steel-tape water-level measurements include mechanical stretch and thermal expansion of the tape. Multiconductor-cable measurements are corrected using a regression equation obtained during calibration of the unit. All measurements, except those at wells $\mathrm{J}-11, \mathrm{~J}-12$, and $\mathrm{J}-13$, are corrected for borehole deviation from vertical. Borehole-deviation information is not available for wells $\mathrm{J}-11, \mathrm{~J}-12$, and $\mathrm{J}-13$. All measurements are referenced to sea-level datum. 
Table 2. Corrections applicable to steel tapes used for measuring water levels, 1994, in the vicinity of Yucca Mountain

$[--$, not applicable $]$

\begin{tabular}{|c|c|c|c|c|c|c|c|c|c|c|c|}
\hline \multirow{2}{*}{$\begin{array}{l}\text { Well name } \\
\text { (superscript is } \\
\text { tube \# or } \\
\text { intervai) }\end{array}$} & \multirow{2}{*}{$\begin{array}{c}\text { Assumed } \\
\text { average air } \\
\text { temperature, } \\
\text { In well } \\
\text { (degrees } \\
\text { Celsius) }\end{array}$} & \multicolumn{3}{|c|}{$\begin{array}{l}\text { Correction for 2,800-foot } \\
\text { reference steel tape } \\
\text { (meters) }\end{array}$} & \multicolumn{3}{|c|}{$\begin{array}{c}\text { Correction for Chain \#3 } \\
\text { (meters) }\end{array}$} & \multirow{2}{*}{$\begin{array}{l}\text { Correction } \\
\text { for hole } \\
\text { deviation } \\
\text { from vertical } \\
\text { (meters) }\end{array}$} & \multicolumn{2}{|c|}{$\begin{array}{c}\begin{array}{c}\text { Measuring point } \\
\text { (meters) }\end{array} \\
\text { Interval }^{2}\end{array}$} & \multirow{2}{*}{$\begin{array}{l}\text { Reference } \\
\text { point } \\
\text { (meters) }\end{array}$} \\
\hline & & $\begin{array}{l}\text { Mechanical } \\
\text { stretch }\end{array}$ & $\begin{array}{l}\text { Thermal } \\
\text { expansion }\end{array}$ & Total 1 & $\begin{array}{l}\text { Mechanical } \\
\text { stretch }\end{array}$ & $\begin{array}{l}\text { Thermal } \\
\text { expansion }\end{array}$ & Total ${ }^{1}$ & & Upper & Lower & \\
\hline USW WT-1 & 25.0 & -0.043 & 0.027 & -0.016 & -0.019 & 0.027 & 0.008 & -0.326 & 0.314 & 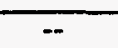 & $1,201.11$ \\
\hline USW WT-2 & 24.4 & -0.038 & 0.029 & -0.009 & -0.010 & 0.029 & 0.019 & -0.445 & 0.311 & -- & $1,301.13$ \\
\hline UE-25 WT \#3 & 26.1 & -0.041 & 0.021 & -0.020 & -0.024 & 0.021 & -0.002 & -0.271 & 0.155 & -- & $1,030.11$ \\
\hline UE-25 WT \#4 & 25.0 & -0.044 & 0.025 & -0.019 & -0.021 & 0.025 & 0.004 & -0.454 & 0.311 & - & $1,169.21$ \\
\hline UE-25 WT \#6 & 23.3 & -0.040 & 0.011 & -0.029 & -0.023 & 0.011 & -0.012 & -0.204 & 0.463 & -- & $1,314.78$ \\
\hline USW WT-7 & 27.8 & -0.044 & 0.038 & -0.006 & -0.022 & 0.038 & 0.016 & -0.034 & 0.302 & -- & $1,196.88$ \\
\hline USW WT-10 & 29.4 & -0.043 & 0.038 & -0.005 & -0.024 & 0.038 & 0.014 & -0.030 & 0.314 & - & $1,123.40$ \\
\hline USW WT-11 & 28.3 & -0.044 & 0.035 & -0.009 & -0.023 & 0.035 & 0.012 & -0.116 & 0.311 & -- & $1,094.11$ \\
\hline UE-25 WT \#12 & 27.2 & -0.043 & 0.029 & -0.014 & -0.024 & 0.029 & 0.005 & -0.183 & 0.305 & - & $1,074.74$ \\
\hline UE-25 WT \#13 & 24.4 & -0.041 & 0.015 & -0.026 & -0.024 & 0.015 & -0.008 & -0.012 & 0.305 & -- & $1,032.51$ \\
\hline UE-25 WT \#14 & 24.4 & -0.043 & 0.018 & -0.025 & -0.024 & 0.018 & -0.006 & -0.085 & 0.311 & -- & $1,076.05$ \\
\hline UE-25 WT \#15 & 23.9 & -0.043 & 0.016 & -0.027 & -0.024 & 0.016 & -0.008 & -0.189 & 0.314 & $\cdots$ & $1,082.94$ \\
\hline UE-25 WT \#16 & 26.1 & -0.043 & 0.033 & -0.010 & -0.019 & 0.033 & 0.015 & -0.064 & 0.314 & -- & $1,210.63$ \\
\hline UE-25 WT \#17 & 25.0 & -0.044 & 0.023 & -0.021 & -0.023 & 0.023 & 0.000 & -0.482 & 0.158 & - & $1,124.06$ \\
\hline UE-25 WT \#18 & 25.1 & -0.035 & 0.036 & 0.001 & -0.006 & 0.036 & 0.030 & -0.155 & 0.210 & - & $1,336.32$ \\
\hline UE-25b \#1 & 25.6 & -0.043 & 0.031 & -0.013 & -0.019 & 0.031 & 0.012 & -0.244 & 0.302 & 0.134 & $1,200.73$ \\
\hline UE-25p \#1 & 25.6 & -0.044 & 0.024 & -0.020 & -0.023 & 0.023 & 0.000 & -0.021 & 0.158 & -- & $1,114.21$ \\
\hline USW G-2 & 22.8 & -0.041 & 0.017 & -0.024 & -0.015 & 0.017 & 0.002 & -0.158 & .0 .332 & & $1,553.86$ \\
\hline USW G-3 & 23.3 & -0.015 & 0.029 & 0.013 & 0.017 & 0.029 & 0.045 & -0.564 & 0.329 & - & $1,480.47$ \\
\hline USW H-1 ${ }^{\text {tube } 1}$ & 25.0 & -0.042 & 0.030 & -0.012 & -0.015 & 0.030 & 0.015 & -0.143 & 0.311 & -- & $1,303.10$ \\
\hline USW H-1 $1^{\text {tube } 2}$ & 25.0 & -0.038 & 0.033 & -0.005 & -0.011 & 0.033 & 0.022 & -0.171 & 0.311 & - & $1,303.10$ \\
\hline USW H-1 ${ }^{\text {tubes } 3,4}$ & 25.0 & -0.038 & 0.033 & -0.005 & -0.010 & 0.033 & 0.023 & -0.174 & 0.311 & - & $1,303.10$ \\
\hline USW H-3 ${ }^{\text {upper }}$ & 26.1 & -0.015 & 0.053 & 0.038 & 0.017 & 0.053 & 0.070 & -0.079 & 0.174 & - & $1,483.47$ \\
\hline USW H-3 $3^{\text {lower }}$ & 26.1 & -0.019 & 0.052 & 0.033 & 0.013 & 0.052 & 0.064 & -0.058 & - & 0.201 & $1,483.47$ \\
\hline USW H-4 & 24.4 & -0.042 & 0.026 & -0.015 & -0.015 & 0.026 & 0.011 & -0.064 & 0.597 & 0.308 & $1,248.74$ \\
\hline USW H-5 & 23.9 & -0.023 & 0.032 & 0.009 & 0.008 & 0.032 & 0.040 & -0.079 & 0.329 & 0.235 & $1,478.94$ \\
\hline USW H-6 & 25.0 & -0.041 & 0.031 & -0.011 & -0.015 & 0.031 & 0.016 & -0.052 & 0.207 & 0.235 & $1,302.06$ \\
\hline USW VH-1 & 23.9 & -0.031 & 0.008 & -0.022 & -0.019 & 0.008 & -0.011 & -0.049 & 0.631 & - & 963.23 \\
\hline Well J-11 & 25.0 & -0.042 & 0.018 & -0.023 & -0.024 & 0.018 & -0.005 & unknown & 0.555 & -- & $1,049.45$ \\
\hline Well J-12 & 25.0 & -0.035 & 0.013 & -0.022 & -0.022 & 0.013 & -0.008 & unknown & 0.527 & -- & 954.54 \\
\hline Well J-13 & 25.0 & -0.040 & 0.016 & -0.023 & -0.023 & 0.016 & -0.007 & unknown & 0.165 & -- & $1,011.47$ \\
\hline
\end{tabular}

'Total correction may not equal sum of mechanical stretch and thermal expansion due to rounding.

${ }^{2}$ Wells with only one interval have measuring point listed as upper. 


\section{Mechanical Stretch}

Mechanical stretch is associated with the weight of the suspended steel tape and attached plumb bob (Garber and Koopman, 1968, and Robison and others, 1988). The calculated adjustment for the steel tapes used during 1994, based on stretch coefficients and an approximate weight of $0.45 \mathrm{~kg}$ for the plumb bob, ranged from -0.044 to $0.017 \mathrm{~m}$ (table 2) for water levels measured in the vicinity of Yucca Mountain.

The correction for mechanical stretch of the tape is given by:

$$
\mathrm{C}=\left(\mathrm{L}^{2} \mathrm{WS}\right) / 2+\mathrm{PLS}-\mathrm{KLS}
$$

where,

$\mathrm{C}$ is the correction, in meters;

$L$ is the apparent length of tape, in meters;

$\mathrm{W}$ is the unit weight of the tape, in kilograms per meter;

$S$ is the stretch coefficient, in meters per (meter kilogram);

$P$ is the weight of the plumb bob, in kilograms; and

$\mathrm{K}$ is reference tension during manufacture, in kilograms.

Values for W were determined at a calibration laboratory at the NTS, and values for S were determined by the U.S. Geological Survey and are estimated to be accurate to 7 percent (R.R. Luckey, U.S. Geological Survey, oral commun., 1993). Values for the reference tension (K) are provided by the manufacturer at the time of purchase.

When a steel tape is manufactured, the manufacturer's calibrated length of the tape assumes that a specific tension (the reference tension, $\mathrm{K}$ ) will be placed on the tape. For most wells measured for this report, the depth to water was shallow enough that the tension placed on the steel tape used to make the measurement was less than the manufacturer's reference tension. The correction value for these wells was a negative number which was subtracted from the depth-to-water value of the well. For those wells that the depth to water was deep enough that the tension placed on the steel tape was greater than the manufacturer's reference tension, the value was a positive number and added to the depth-to-water value of the well.

\section{Thermal Expansion}

Thermal expansion of a steel tape or a multiconductor cable occurs because of temperature changes. The calculated correction for thermal expansion for steel tapes is based on manufacturer specifications for thermal-expansion coefficients and on average hole temperatures calculated from temperature profiles in wells at Yucca Mountain (Garber \& Koopman, 1968, and Sass and Lachenbruch, 1982). The correction ranges from +0.008 to $+0.053 \mathrm{~m}$ (table 2).

Correction for thermal expansion of the tape is given by:

$$
E=(D-R) T L \text {, }
$$

where,

$\mathrm{E}$ is the correction, in meters;

$\mathrm{D}$ is the assumed average air temperature in the well, in degrees Celsius;

$\mathbf{R}$ is the reference temperature during manufacture, in degrees Celsius;

$\mathbf{T}$ is the thermal expansion coefficient, in meters per meter-degree Celsius; and

$\mathrm{L}$ is the apparent length of the tape, in meters. 
Equation 2 differs from that of Garber \& Koopman (1968, p. 4). The correction for thermal expansion in their report was subtracted from the measured depth to water when it should have been added (J.H. Robison, U.S. Geological Survey, written commun., 1985).

The tape corrections, which include mechanical stretch and thermal expansion, and average air temperature in the well, are given in table 2. Approximate depth to water is analogous to apparent length of the tape, $L$, in equations 1 and 2. The tape-dependent variables for equations 1 and 2 are defined for each tape in table 3.

Table 3. Mechanical stretch and thermal expansion equation variable values for steel tapes used in the vicinity of Yucca Mountain

\begin{tabular}{lcc}
\multicolumn{1}{c}{ Variable } & $\begin{array}{c}2,800-\text { foot } \\
\text { reference steol tape }\end{array}$ & Chain *3 \\
\hline Unit weight of the tape, W (kilogram/meter) & $2.08 \times 10^{-2}$ & $2.65 \times 10^{-2}$ \\
Stretch coefficient, S [meter/(meter kilogram)] & $2.48 \times 10^{-5}$ & $1.69 \times 10^{-5}$ \\
Weight of plumb bob, P (kilogram) & 0.45 & 0.45 \\
Reference tension during manufacture, K (kilogram) & 9.07 & 9.07 \\
Reference temperature during manufacture, R (degree Celsius) & 20 & 20 \\
Thermal expansion coefficient, T [meter/(meter degree Celsius)] & $1.16 \times 10^{-5}$ & $1.16 \times 10^{-5}$ \\
\hline
\end{tabular}

\section{Multiconductor-Cable Correction}

Calibrations used to correct water-level data obtained with the multiconductor-cable unit were performed from November 23 to December 9, 1993. Measurements were made with the multiconductor unit and the reference tape in three wells that span the range of depths to water normally found in the Yucca Mountain area. For each well, a correction factor was determined to make the multiconductor-cable measurement consistent with the reference-tape measurement. The use of a single, average correction factor, such as that used by $O^{\prime} B$ Brien $(1991$, p. 14), was not appropriate, because the correction factor was linearly dependent on depth. An equation relating the correction factor to depth to water was determined, and was applied at each well in which the multiconductor unit was used. This equation is

$$
y=-0.0013658 x+0.13
$$

where,

$y$ is the correction factor, in meters, and

$\mathrm{X}$ is the apparent depth to water, in meters.

For example, if the apparent depth to water is $300 \mathrm{~m}$, the correction factor is $-0.28 \mathrm{~m}$. This correction factor is applied in place of the mechanical stretch and thermal expansion corrections for the steel tapes; however, the borehole-deviation correction is also applied.

Sheave slippage occurs with the multiconductor cable because of change in diameter of the sheave or operator error. Slippage can vary with hoist design, but errors can be minimized by comparing IN and OUT readings of water levels. The sheaves used for depth indicators can wear, eventually causing measurement errors. Annual calibration of the multiconductor-cable unit decreases this error and, along with visual inspection of the sheave, indicates when the sheave needs to be replaced. This factor is not applicable to steel tapes that have permanently marked units.

\section{Borehole-Deviation Correction}

In addition to the corrections for mechanical stretch, thermal expansion, and multiconductorcable correction, corrections must also be made for boreholes that are not vertical (borehole 
deviation). Gyroscopic surveys were made in all measured wells except wells J-11, J-12, and J-13. The gyroscopic surveys measured borehole deviation from vertical. The difference between measured depth and true vertical depth is the borehole deviation, or borehole correction. Corrections for most wells are $-0.2 \mathrm{~m}$ or less, but they range from -0.01 to $-0.56 \mathrm{~m}$ (table 2 ). Corrections generally increase with increasing well depth.

\section{Water-Level Altitudes}

Water-level altitudes are calculated by subtracting the corrected depth to water from the altitude of the reference point, which generally is a metal tag on the well casing. The measuring point for the wells, at the top of the access tube, is at some distance above the reference point, and the height of the measuring point is subtracted from the apparent depth to water to calculate the corrected depth to water. Reference-point and measuring-point values for all wells are listed in table 2 , and described in the individual well sections. Water-level altitudes in this report generally are based on a survey of the water-level monitoring network reference points made in late 1984 by the U.S. Geological Survey.

\section{Example Calculations}

Example measurements for well UE-25 WT \#4 for March 16, 1994, and for well UE-25b \#1, lower interval for January 19, 1994, are presented to illustrate the calculations made to derive the altitude of the water level. The calculated altitude is the value reported in the section "Well Data and Water Levels."

At least two measurements of the water level are made and averaged during each visit to the well, and the appropriate corrections are applied after averaging the two water-level measurements. Additional measurements are made only if the two measured depths differ by more than $0.05 \mathrm{ft}$.

\section{Example A: Chain \#3}

The water-level measurement on March 16, 1994, at UE-25 WT\#4 was made with Chain \#3. The HELD is the indicated footage on the tape when it is held at the MP during a measurement, and CUT is the footage of tape that is wetted during its submersion in the water. The difference between HELD and CUT is the apparent depth to water below the MP.

The measurements and corrections for UE-25 WT \#4 on March 16, 1994, were:

\begin{tabular}{|c|c|c|c|}
\hline Reading & $\begin{array}{c}\text { Measurement } \\
1\end{array}$ & $\begin{array}{c}\text { Measurement } \\
2\end{array}$ & \\
\hline HELD (ft) & $1,442.00$ & $1,443.00$ & \\
\hline CUT (ft) & -1.31 & -2.31 & \\
\hline Apparent depth to water $(\mathrm{ft})$ & $1,440.69$ & $1,440.69$ & \\
\hline Average of two apparent depths to water (ft) & & & $1,440.69$ \\
\hline Apparent depth to water $(1,440.69 \mathrm{ft} \times 0.3048 \mathrm{~m} / \mathrm{ft})(\mathrm{m})$ & & & 439.122 \\
\hline Measuring point (m) (table 2) & & & -0.311 \\
\hline Tape correction (m) (table 2) & & & +0.004 \\
\hline Correction for borehole deviation from vertical (m) (table 2) & & & -0.454 \\
\hline Corrected depth below reference point (m) & & & 438.361 \\
\hline \multicolumn{4}{|l|}{ Determination of water-level altitude: } \\
\hline Altitude of reference point (m) (table 2) & & & $1,169.21$ \\
\hline Corrected depth $(\mathrm{m})$ & & & -438.36 \\
\hline Altitude of water level (m) & & & 730.85 \\
\hline
\end{tabular}


Example B: Multiconductor cable

The water-level measurement on January 19, 1994, at UE-25b \#1, lower interval was made with the multiconductor-cable unit. The IN reading is the indicated footage of the cable displayed by the depth indicator when the sensing device (generally a float switch) is at the water surface. The OUT reading is the indicated footage when the sensing device has been withdrawn to the MP.

The measurements and corrections for UE-25b \#1, lower interval on January 19, 1994, were:

\begin{tabular}{|c|c|c|c|}
\hline Reading & $\begin{array}{c}\text { Measurement } \\
1\end{array}$ & $\begin{array}{c}\text { Measurement } \\
2\end{array}$ & \\
\hline IN reading ( $\mathrm{ft}$ ) & $1,545.23$ & $1,545.91$ & \\
\hline OUT reading(ft) & -2.90 & -3.59 & \\
\hline Tool length (ft) & +4.67 & +4.67 & \\
\hline Apparent depth to water ( $\mathrm{ft}$ ) & $1,547.00$ & $1,546.99$ & \\
\hline Average of two apparent depths to water $(\mathrm{ft})$ & & & $1,546.995$ \\
\hline Apparent depth to water $(1,553.485 \mathrm{ft} \times 0.3048 \mathrm{~m} / \mathrm{ft})(\mathrm{m})$ & & & 471.524 \\
\hline Measuring point $(\mathrm{m})($ table 2$)$ & & & -0.134 \\
\hline Cable correction (m) & & & -0.509 \\
\hline Correction for borehole deviation from vertical (m) (table 2) & & & -0.244 \\
\hline Corrected depth below reference point $(\mathrm{m})$ & & & 470.637 \\
\hline \multicolumn{4}{|l|}{ Determination of water-level altitude: } \\
\hline Altitude of reference point (m) (table 2) & & & $1,200.73$ \\
\hline Corrected depth (m) & & & -470.64 \\
\hline Altitude of water level (m) & & & 730.09 \\
\hline
\end{tabular}

\section{Precision and Accuracy}

An analysis of precision and accuracy was conducted for manual water-level measurements, which include all periodic measurements obtained during 1988-90 (Boucher, 1994a). The mean precision range of the $2,800-\mathrm{ft}$ reference steel tape, based on 31 measurements, was $0.026 \mathrm{ft}$. The mean precision range of Chain \#2, based on 341 measurements, was $0.014 \mathrm{ft}$. Ninety-seven percent of all measurements obtained with the steel tapes were precise to within $0.05 \mathrm{ft}$ during 1988-90. The precision of Chain \#3 is not known, but is believed to be the same or nearly the same as that of Chain \#2 because they have nearly the same physical characteristics and they were identically constructed.

The overall accuracy of the computed water-level altitude depends on the individual accuracies of its computational components such as: (1) Water-level measurement, (2) borehole correction, (3) height of the measuring point, (4) altitude of the reference point, and (5) the precision of the 2,800-ft reference steel tape. The total accuracy of measurements taken with the steel tapes during 1988-90 was estimated to be $0.36 \mathrm{ft}$, neglecting the accuracy of the borehole correction factors (Boucher, 1994a). Accuracy of the borehole correction factors is indeterminate because documentation of the borehole-deviation surveys was inadequate to assess their accuracy, and because no borehole-deviation data are available for wells $\mathrm{J}-11, \mathrm{~J}-12$, and $\mathrm{J}-13$. The unknown accuracy of the borehole corrections poses a problem in the calculation of overall accuracy values. 


\section{Hourly Measurements}

Hourly water-level measurements require that equipment be installed in the well to record water levels. Trained personnel install the equipment in the well, periodically calibrate equipment or replace it as necessary, and periodically retrieve the data from the site.

Hourly measurements are of a sufficient frequency that water-level fluctuations are adequately defined to evaluate daily or longer term trends. Hourly measurements are not sufficient, however, to detect short-term water-level fluctuations, such as those induced by earthquakes (O'Brien, 1992). Hourly measurements were stored and later retrieved from the data loggers at each site. Continuous measurements were collected at wells USW H-5 and USW H-6 in 1994 to monitor water-level and fluid-pressure response to earthquakes; however, these continuous data are not included in this report.

Pressure transducers and data loggers are used to measure water-level fluctuations. Because of the large depths to water (up to $752 \mathrm{~m}$ ), traditional water-level sensing methods, such as floatcable-pulley system, water-seeking device, and bubble tube, are not feasible. However, electronic signals from a submerged pressure transducer are relatively easy to transmit through a multiconductor suspension cable to a recording device accessible to personnel on the surface. Electronic data loggers at the surface are used to control, measure, and store data from the pressure transducers.

\section{Equipment}

The hourly water-level network equipment consists of a pressure transducer, which senses depth of submergence, a wireline cable to transmit voltage between the transducer and the surface, and a data logger to control the system, measure the transducer output, and store the data. An external 12-volt battery provides power to the system, and a solar panel charges the battery.

The wireline cable, consisting of four conductors, appropriate insulation, and two external wire wraps (for strength and stability), is used to transmit voltage between the data logger at the surface and the downhole pressure transducer. The required length of wireline cable to monitor a typical well at Yucca Mountain weighs several tens of kilograms, so power equipment is used to install and calibrate the system.

The water-level monitoring systems are calibrated at least every 4 months, and the calibration includes a water-level measurement. The water-level measurements are made using either the transducer, a steel tape, or a multiconductor cable unit. Equipment for the water-level measurements, its use, and the necessary corrections and adjustments, are described in detail by Robison and others (1988) and in previous sections of this report. The water-level measurements, after adjustments, result in altitudes of water surface at the time of calibration.

\section{Transducers}

Water-level fluctuations in the hourly network were measured with pressure transducers and pressure transmitters during 1994. Transducers and transmitters are pressure sensors which convert a change in a mechanical quantity (such as pressure) into a change in an electrical quantity (such as resistance). In this report, the term "transducer" refers to either a depth-measurement pressure transducer or pressure transmitter. These sensors are used to measure pressure and are capable of being immersed in water to measure the depth of submersion. Because the transducer remains at a fixed depth in the well, water-level fluctuations are equivalent to changes in the depth of submersion detected by the transducer. 
The pressure-sensing components of a transducer consist of a strain gage to convert pressure into electrical resistance and a Wheatstone bridge to allow measurement of the change in resistance. The major difference between pressure transducers and transmitters is the form of the input and output. Pressure transducers use voltage as input and output, whereas pressure transmitters use current as input and output. Pressure transmitters are constructed with the same strain gage and Wheatstone bridge arrangement as a pressure transducer; however, the current input is converted to voltage by an amplifier before it enters the strain gage and the voltage is converted back to current by a regulator after it passes through the Wheatstone bridge. The required wiring of pressure transducers and transmitters differs because the data loggers are not capable of measuring current. The output signal of a transmitter must be connected to a resistance load, and the drop in voltage across the load is then measured by the data logger. Regardless of which type of pressure sensor is used, the transducer output increases as the depth of submergence increases.

Transducers are made for a range of pressures. Generally, the smaller the pressure range of the transducer the more accurately pressure changes and water-level fluctuations can be measured. Transducer pressure ranges used in the hourly water-level network were $2.5,5$, and $20 \mathrm{psi}$ (pounds per square inch); however, the 5 psi range was most commonly used.

The water-level network historically has used both absolute and gage transducers. An absolute transducer measures pressure relative to a fixed reference pressure, whereas a gage transducer measures pressure relative to atmospheric pressure. A gage transducer has a vent tube from the reference side of the strain gage to a point above the water surface. Gage transducers are preferable in the water-level network because only water-level fluctuations (and not air-pressure changes) affect the transducer output, and these were used exclusively in the water-level network during 1994.

As a part of the calibration process, a water-level measurement must be obtained by either a manual measurement, using a steel tape, multiconductor cable, or by "tagging" the water level using the transducer. Tagging the water level, which is the more frequently used method of waterlevel measurement during calibrations, is done by raising or lowering the transducer until it comes in contact with the water surface in the well. The difference in the depth to water from the last manual measurement, indicated by a tape mark on the transducer cable, is then noted in the log book as part of the calibration record. If the transducer is functioning properly, the water level obtained by tagging should be as accurate as a manual measurement; however, if the transducer is not functioning properly, errors in the measured water level (probably less than $0.1 \mathrm{~m}$ ) are possible.

The transducers are calibrated when installed in the well, when removed from the well (if possible), and at least every 4 months while in service in the well. The calibration consists of manually raising or lowering the transducer in increments and noting the change in transducer output. The data logger (described in the next section) is used in the calibration to provide the applied voltage, if necessary, and to measure the output voltage, so the calibration is for the entire transducer/data-logger system and not only for the transducer.

On February 16, 1994, the transducer/data-logger system at well UE-25 WT \#3 was calibrated. The calibration started with the transducer submerged $1.52 \mathrm{~m}$ below the water surface. The following values were obtained: 


\begin{tabular}{|cc|}
\hline $\begin{array}{c}\text { Depth of submergence } \\
\text { below water surface } \\
\text { (meters) }\end{array}$ & $\begin{array}{c}\text { Average transducer output } \\
\text { (millivolts) }\end{array}$ \\
\hline 1.52 & 45.15 \\
1.22 & 38.35 \\
1.16 & 37.00 \\
1.10 & 35.59 \\
1.04 & 34.26 \\
0.98 & 32.78 \\
0.91 & 31.43 \\
0.85 & 30.09 \\
0.79 & 28.72 \\
0.73 & 27.37 \\
0.67 & 25.99 \\
0.61 & 24.92 \\
0.30 & 17.61 \\
0.00 & 10.68 \\
\hline
\end{tabular}

The transducer output is the average of three readings taken after the transducer output had stabilized. A regression analysis was performed on the calibration data, excluding any points where the transducer was not submerged. The slope of the regression line for well UE-25 WT \#3 on February 16, 1994, was 0.044 meters per millivolt with a coefficient of determination $\left(\mathrm{r}^{2}\right)$ of 100.0 percent. The slope of the regression line, the transducer output at the set point after calibration and before the next calibration, and the water-level measurement at the time of calibration were used to convert transducer output to water-level altitude. The set point is the position below the water surface at which the transducer is placed for water-level monitoring.

\section{Data Loggers}

Data-collection platforms (DCP's) that collect, store, and transmit data to a satellite from which the data are relayed to a ground station, were used as the primary data-acquisition system during 1994. The Campbell Scientific 21X Micrologger, used in the hourly water-level network as the primary data-acquisition system prior to 1993 , is a microprocessor-based system that was used as a supplemental data-acquisition system at selected wells. Details of the 21X Micrologger operation and programming are described by Luckey and others (1993) and Lobmeyer and others (1995).

A DCP was first installed at well USW G-3 in December 1989, and at all hourly monitored wells by May 1993. Handar model 570A units were the DCP's used to replace the 21 X Micrologger system. The DCP has the same functions as a micrologger, but, in addition to internal storage of data, data are transmitted to a Geostationary Operational Environmental Satellite (GOES). Details of DCP use and operation, and GOES systems are described by Blee and others (1986). Data are collected hourly, stored, and transmitted every 4 hours to a GOES satellite. The data are then relayed to a Direct Readout Ground Station (DRGS) and stored in USGS computers for evaluation and further processing. Data stored internally in the DCP are periodically transferred to computer diskettes. These data are used as backups to the transmitted data, and are used to fill in data gaps due to any malfunctions in the transmission or receiving process.

In addition to transducer output, the data loggers also read information such as battery voltage, excitation voltage, and the panel temperature of the data loggers. These variables are important in evaluation of the reliability of the system. The data loggers store all of the preceding data in memory. Data from the DCP's periodically are transferred to computer diskettes using a portable computer; station ID and time tags are written at the beginning and end of each data file. 


\section{Processing and Adjustments}

The data stored in the data loggers and transferred to computers are not water-level data but rather transducer output, in millivolts. The transducer output are converted to water levels, as explained in the following section, "Conversion to Water-Level Altitude." The water-levels are then evaluated. Anomalous data points, such as those produced during transducer calibrations, by random electronic signals, or due to instrument malfunction are not retained as water levels.

\section{Conversion to Water-Level Altitude}

In an ideal circumstance, a transducer would be calibrated several times during its operating life, its output would be free of drift, and its characteristics would not change with time. However, this ideal situation rarely occurred, causing the transducer output conversion to be more difficult. As a result, some of the transducer output and resulting converted water levels were not considered reliable.

Converted water levels were evaluated for data reliability. The data were examined at a time scale which clearly showed the hourly and daily fluctuations so that the validity of the data could be determined. The data were compared to barometric-pressure data, earth-tide potential data, and other periods of record for the same site and depth interval. If the data were independently validated, the data were retained and included in this report. If the data were not validated independently, the data were given indeterminate status and are not included in this report. is:

The equation for converting transducer output to water-level altitude under ideal conditions

$$
W=W_{c}+\left(T-T_{c}\right) \bullet S_{c}
$$

where,

$W$ is the water-level altitude, in meters;

$\mathrm{W}_{\mathrm{c}}$ is the water-level altitude at calibration, in meters;

$S_{c}$ is the slope of the regression line, in meters per millivolt;

$\mathrm{T}_{\mathrm{c}}$ is the transducer output at set point following calibration, in millivolts; and

$T$ is the transducer output, in millivolts.

Equation 4 is from O'Brien and others (1995).

The following example calculation from UE-25 WT \#3 illustrates how transducer data was converted to water levels. The water-level altitude for the calibration on February 16, 1994, was $729.72 \mathrm{~m}$ (based on a manual measurement). The calibration indicated that a $0.044-\mathrm{m}$ change in water level would cause the transducer output to change by approximately 1 millivolt. The transducer output at the post-calibration set point $(0.91 \mathrm{~m}$ below water surface) was 31.39 millivolts. The transducer output at 15:00:00 on February 16, 1994, was 32.03 millivolts. To summarize, equation 4 variables are:

$\mathrm{W}_{\mathrm{c}}=729.72$ meters

$\mathrm{S}_{\mathrm{c}}=0.44$ meters $/$ millivolt

$\mathrm{T}_{\mathrm{c}}=31.39$ millivolts

$\mathrm{T}=32.03$ millivolts 
Given these data, the water-level calculation for 15:00:00 on that date, would be as follows:

$$
\mathrm{W}=729.72+(32.03-31.39) \bullet 0.044=729.75 \text { meters }
$$

Change in the slope of the regression line, $S_{c}$, and change in the transducer output at set point, $\mathrm{T}_{\mathrm{c}}$, between consecutive calibrations, are types of drift corrected for in the conversion process. Although the slope of the regression line generally does not change dramatically between calibrations, it usually changes to some degree. The change in slope is assumed to be linear between calibrations. Set-point drift occurs when the expected transducer output (based on manual tags) does not match the actual measured set-point output. Set-point drift is also assumed to be linear over time.

The water-level altitude is assumed to have remained constant from the last transducer output prior to calibration through the first transducer output after calibration. This assumption probably introduces, at most, a few hundredths of a meter error in the calculation of water-level altitude. If more than one calibration was done on a transducer on the same day, the last calibration is used to calculate water-level altitude for the following period unless the coefficients of determination of the regression lines indicated that another calibration was superior.

\section{Quality Assurance}

Data in this report will be used to evaluate the suitability of the Yucca Mountain site for a high-level nuclear-waste repository. Confidence in the reliability of water-level data is necessary so the data may be used to assess the expected performance of the repository. A quality-assurance program has been implemented to support the reliability of the data.

\section{Onsite Procedures}

The quality-assurance program requires that water-level measurements be obtained by methods described by formal technical procedures. The technical procedures include calibrations and adjustments done during the measuring operation to ensure that the equipment is operating properly and that expected precision and accuracy are attained. For example, the procedure for measuring water-level changes with a pressure transducer specifies how to install the transducer, how to calibrate, and how to maintain the records of the calibrations.

Data are recorded in logbooks at the well site. Data recorded include: time and date of the visit; names of operators making the visit; identification of specific equipment used; calibration data; water-level measurement data; and correction factors, if any, applied to the data at the well site. In addition, the entry in the logbooks may include comments concerning factors that may be relevant to the collected data, such as discussion of problems with equipment or weather conditions during the water-level measurement or transducer calibration.

\section{Office Processing and Review}

The original logbooks and records are maintained throughout the calendar year at the onsite operations headquarters on the Nevada Test Site. The records are reviewed for completeness and accuracy and to ensure that proper technical procedures were followed. Any needed adjustments not done during onsite operations, such as tape and borehole-deviation corrections, are made in the Denver office. After independent data review and any needed adjustments, the logbooks and related records are transferred to a Yucca Mountain Project archive in Denver. 
The transducer output is entered into a temporary computer data base and is plotted to facilitate data review and to discover any instrumentation problems. After this review, the transducer output is converted to water levels. The converted water-level data are reviewed for technical quality. In addition to being published by the U.S. Geological Survey, both the raw transducer output and the water-level altitudes are placed in permanent computer data bases, such as the Unit Values file of the NWIS used by the U.S. Geological Survey. Water-level altitudes obtained from manual measurements are also placed in the computer data base.

\section{WELL DATA AND WATER LEVELS}

This section contains information and data of all wells monitored as part of the Yucca Mountain Potentiometric Site Studies Project during 1994. Previously published water-level data reports divided this section into two subsections "Periodic water-level measurements" and "Hourly water-level measurements". However, for this report, each well is listed and discussed in the order listed in table 1, without a division of periodic or hourly subsections. Information for each well includes source of information about the well, of which most is published information. Borehole-geophysical logs and coremeasurement data for the wells are given by Nelson and others (1991). Previously collected water-level data can be found in Boucher (1994b), Gemmell (1990), Lobmeyer and others (1995), Luckey and others (1993), O'Brien (1991, 1992, and 1993), O'Brien and others (1995), Tucci, O'Brien, and Burkhardt (1996), and Tucci, Goemaat, and Burkhardt (1996). Complete bibliographic citations are in the "References Cited" section. Important information about each well (location and identification, drilling and casing information, access to and description of interval for measuring water levels, and information for calculation of water-level altitude) are summarized in the "Well Specifications" subsection of each well. Although water-level altitudes are corrected for borehole deviation, other depth-related values (such as casing or access-tube depths) in this subsection are uncorrected. Various statistical information concerning the water levels, and hydrographs of water-level altitudes are also presented for each well. Hydrographs are uniformly plotted for calender year 1994 with a y-axis (water-level) span of $2.5 \mathrm{~m}$.

Additional information included for each well is specific to the frequency of data collection (periodic or hourly measurements). For wells that were measured periodically at any time during the year, a table with the periodic measurement and method of measurement is included. For wells that were measured hourly at any time during the year, two tables are shown, one with the transducer calibration information and the other with the mean monthly water levels for the months the hourly measurements were made. The mean monthly levels were calculated from available daily-mean values. The monthly values were calculated regardless of the number of missing daily-mean values. Calibration information includes the transducer serial number, calibration date, slope of the regression line, coefficient of determination, and the water-level altitude determined at the time of calibration. Comments concerning any special conditions or information that might affect the results of the calibrations or conversion of data to water levels are included, as well as explanations for periods of missing water-level data.

The mean annual 1994 water-level altitude is given and compared to the mean annual 1993 waterlevel altitude for each well, regardless of the frequency of data collected. For wells that were measured hourly at any time during 1994, the mean annual water-level altitude used to compare to the 1993 data was calculated solely from the hourly data. For those wells which were only measured periodically, the mean annual water-level altitude is calculated from the periodic measurements. There is no distinction made in comparison of the 1993 and 1994 mean water-level altitude. The comparison is made to the 1993 value reported in Tucci, Goemaat, and Burkhardt (1996), regardless of whether the frequency of measurement was the same between 1993 and 1994.

Hydrographs of wells monitored periodically are plots of the periodic data. Hydrographs of wells monitored hourly are plots of the daily-mean values of the hourly data. Only those hourly values that were evaluated as "valid" were used to calculate the daily-mean values. For any day that 6 or more consecutive hours of data were missing, a daily-mean value was not calculated. Hydrographs of wells monitored periodically and hourly includes both sets of data. For identification purposes on hydrographs of 
combined data, the periodic data is labeled as "PERIODIC MEASUREMENTS" and the daily-mean values are labeled as "HOURLY MEASUREMENTS."

Annual minimum and maximum water-level altitudes are presented for each well. For wells monitored periodically, the range of water-level altitudes is from the periodic measurement. For wells monitored hourly the range of water-level altitudes is from the daily-mean values of the hourly data. For wells monitored periodically and hourly, the range of water-level altitudes is from the combined sets of data.

On an average, mean 1994 water levels were lower than 1993 mean water levels. However, the average difference was only $0.01 \mathrm{~m}$ lower. Mean water levels ranged from $1.35 \mathrm{~m}$ higher (USW H-3, lower interval) to $0.18 \mathrm{~m}$ lower (USW G-2) than 1993 mean levels. The water-level rise in well USW H-3, lower interval, is anomalously large because the water level in this interval is still equilibrating in response to well reconfiguration in 1990. The 1994 average of $0.01 \mathrm{~m}$ lower than 1993 mean levels does not include the data for the lower interval of USW H-3. 


\section{Well USW WT-1}

Information about the history of well USW WT-1 and about previous data from the well was obtained from various sources. These sources are: Robison (1984, 1986); Robison and others (1988); Holmes \& Narver, Inc. (written commun., 1986); and Fenix \& Scisson, Inc. (1986a, 1987c).

\section{Well specifications}

1. Location and identification:

Latitude and longitude: $36^{\circ} 49^{\prime} 16^{\prime \prime} \mathrm{N}$.; $116^{\circ} 26^{\prime} 56^{\prime \prime} \mathrm{W}$.

Nevada State Central Zone Coordinates (m): N 229,801; E 171,828.

U.S. Geological Survey Site ID: 364916116265601.

2. Drilling and casing information:

Well started: April 28, 1983.

Well completed: May 18, 1983.

Drilling method: Rotary, using rock bits and air, water, and soap-circulating medium; core obtained from bottom of the borehole.

Bit diameter below water level: $222 \mathrm{~mm}$.

Casing: Surface casing only, to a depth of $9.91 \mathrm{~m}$.

Total drilled depth: $515 \mathrm{~m}$.

3. Access to and description of interval for measuring water levels:

62-mm inside-diameter tubing that has a 3.7-m-long well screen on the bottom; tubing and attached screen extend from land surface to a depth of $507.5 \mathrm{~m}$; saturated interval of the borehole is within the Calico Hills Formation and Bullfrog Tuff of the Crater Flat Group.

4. Information for calculating water-level altitude:

Reference point: Top of metal tag on well casing, altitude 1,201.11 m (surveyed by U.S. Geological Survey, 1984).

Measuring point: Top of access tube, $0.314 \mathrm{~m}$.

Depth correction for borehole deviation from vertical: $0.326 \mathrm{~m}$, based on approximate depth to water of $471 \mathrm{~m}$ (1990 data).

Well USW WT-1 was measured periodically and hourly during 1994. Periodic measurements were made through June 3,1994, using Chain \#3 with the following results:

\begin{tabular}{ccc}
\hline Date & $\begin{array}{c}\text { Messured water-level altitude } \\
\text { (moters, above sea level) }\end{array}$ & Mothod \\
\hline $02-02-94$ & 730.29 & Chain \#3 \\
$03-01-94$ & 730.20 & Chain \#3 \\
$03-16-94$ & 730.33 & Chain \#3 \\
$05-02-94$ & 730.28 & Chain \#3 \\
$05-26-94$ & 730.29 & Chain \#3 \\
$06-03-94$ & 730.30 & Chain \#3 \\
\hline
\end{tabular}


The well was instrumented with a transducer on June 3,1994, and hourly measurements were collected for the remainder of the year. During the period of hourly measurements, two calibrations of one transducer were performed. In addition, a calibration was completed on January 18, 1995. This calibration was used to calculate water-level altitudes at the end of 1994. Results of the calibrations and measured water-level altitudes obtained during the calibration are as follows:

\begin{tabular}{|c|c|c|c|c|}
\hline $\begin{array}{l}\text { Transducer serial } \\
\text { number }\end{array}$ & Callibration date & $\begin{array}{c}\text { Slope } \\
\text { (metera/millivolt) }\end{array}$ & $\begin{array}{l}\text { Coefficient of } \\
\text { determination }\end{array}$ & $\begin{array}{l}\text { Water-level } \\
\text { altitude' } \\
\text { (meters) }\end{array}$ \\
\hline 567097 & $06-03-94$ & 0.089 & 1.00 & 730.30 \\
\hline 567097 & $09-15-94$ & .089 & 1.00 & 730.29 \\
\hline 567097 & $01-18-95$ & .089 & 1.00 & 730.28 \\
\hline
\end{tabular}

All transducer data collected for USW WT-1 for 1994 were considered to be valid with no lost record from June 3, 1994, through the end of the year.

Water-level altitudes for well USW WT-1 ranged from 730.20 to $730.44 \mathrm{~m}$ above sea level in 1994 (fig. 2). Mean monthly water-level altitudes for June through December 1994, are listed in table 4. The mean annual water-level altitude for 1994 was $730.33 \mathrm{~m}$ above sea level. This mean altitude was $0.05 \mathrm{~m}$ higher than the mean altitude of $730.28 \mathrm{~m}$ for 1993 (Tucci, Goemaat, and Burkhardt, 1996). 


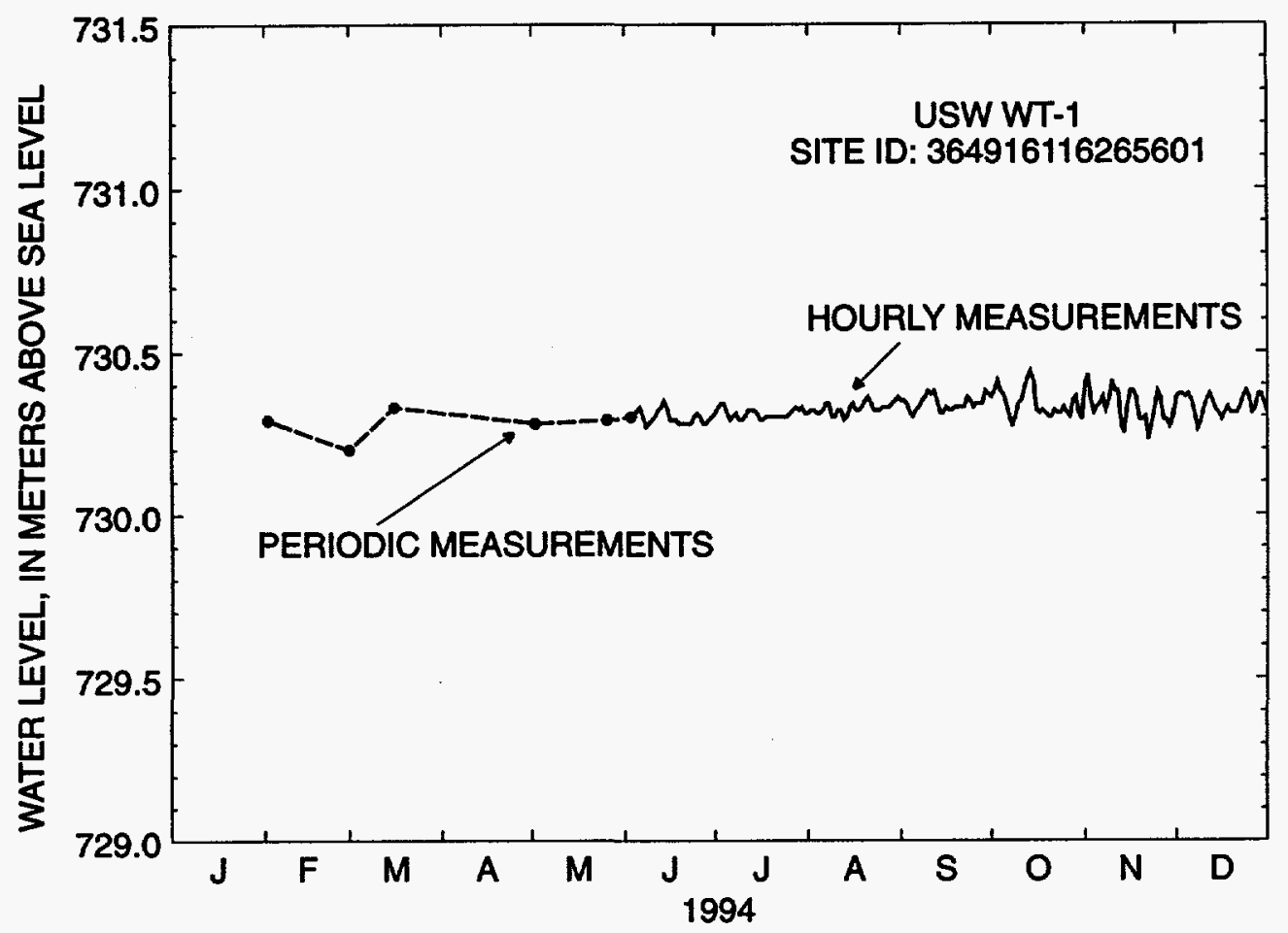

Figure 2. Water-level altitudes, 1994, for well USW WT-1.

Table 4. Mean monthly water-level altitudes, 1994, for well USW WT-1

[Monthly means were calculated regardless of the number of days of missing data. Daily means were not calculated if 6 or more consecutive hours of data were missing; --., data not available; NA, not applicable, well not instrumented during this month]

\begin{tabular}{lcc}
\hline Month & $\begin{array}{c}\text { Water-level altitude } \\
\text { (mmeters, above } \\
\text { soa level) }\end{array}$ & $\begin{array}{c}\text { Number of missing } \\
\text { dally means }\end{array}$ \\
\hline January & --- & NA \\
February & -- & NA \\
March & --- & NA \\
April & --- & NA \\
May & -- & NA \\
June & 730.30 & 3 \\
July & 730.31 & 0 \\
August & 730.33 & 0 \\
September & 730.34 & 0 \\
October & 730.34 & 0 \\
November & 730.33 & 0 \\
December & 730.33 & 0 \\
\hline
\end{tabular}




\section{Well USW WT-2}

Information about the history of well USW WT-2 and about previous data from the well was obtained from various sources. These sources are: Robison $(1984,1986)$; Robison and others (1988); and Fenix \& Scisson, Inc. (1986a, 1987c).

\section{Well specifications}

1. Location and identification:

Latitude and longitude: $36^{\circ} 50^{\prime} 23^{\prime \prime} \mathrm{N} . ; 116^{\circ} 27^{\prime} 18^{\prime \prime} \mathrm{W}$.

Nevada State Central Zone Coordinates (m): N 231,849; E 171,274.

U.S. Geological Survey Site ID: 365023116271801.

2. Drilling and casing information:

Well started: July 8, 1983.

Well completed: July 16, 1983.

Drilling method: Rotary, using rock bits and air-foam circulating medium; core obtained from bottom of the borehole.

Bit diameter below water level: $222 \mathrm{~mm}$.

Casing: Surface casing only, to a depth of $18 \mathrm{~m}$.

Total drilled depth: $628 \mathrm{~m}$.

3. Access to and description of interval for measuring water levels:

62-mm inside-diameter access tubing that has a 3.6-m-long well screen on bottom, extending from land surface to a depth of $622 \mathrm{~m}$; saturated interval of the borehole is within the Prow Pass Tuff of the Crater Flat Group.

4. Information for calculating water-level altitude:

Reference point: Top of metal tag on well casing; altitude $1,301.13 \mathrm{~m}$ (surveyed by U.S. Geological Survey, 1984).

Measuring point: Top of access tube, $0.305 \mathrm{~m}$ after 12/08/93, $0.146 \mathrm{~m}$ between $9 / 09 / 93$ and $12 / 08 / 93,0.311 \mathrm{~m}$ prior to $9 / 09 / 93$.

Depth correction for borehole deviation from vertical: $0.445 \mathrm{~m}$ after $12 / 08 / 93$ and $0.533 \mathrm{~m}$ prior to $12 / 08 / 93$, based on approximate depth to water of $571 \mathrm{~m}$.

Well USW WT-2 was measured periodically and hourly during 1994. Hourly measurements were made until June 2, 1994; the day the transducer was removed from the well. During the period of hourly measurements, three calibrations of one transducer were performed. In addition, a calibration was completed on December 8, 1993. This calibration was used to calculate water-level altitudes at the beginning of 1994. Results of the calibration and measured water-level altitudes obtained during the calibration are as follows:

\begin{tabular}{ccccc}
\hline $\begin{array}{c}\text { Transducer serial } \\
\text { number }\end{array}$ & Calibration date & $\begin{array}{c}\text { Slope } \\
\text { (meters/millivolt) }\end{array}$ & $\begin{array}{c}\text { Coefficient of } \\
\text { dotermination }\end{array}$ & $\begin{array}{c}\text { Water-level } \\
\text { altitude) } \\
\text { (meters) }\end{array}$ \\
\hline 465819 & $12-08-93$ & 0.088 & 1.00 & 730.55 \\
465819 & $01-05-94$ & .088 & 1.00 & 730.61 \\
465819 & $01-12-94$ & .088 & 1.00 & 730.44 \\
465819 & $06-02-94$ & .087 & 1.00 & 730.52 \\
\hline
\end{tabular}


All transducer data collected for USW WT-2 for 1994 were considered to be valid. However, one break in the data during the time the well was instrumented does exist (January 5 through 12, 1994,) because the transducer was removed from the well so that geophysical logging could be completed in the borehole.

Periodic measurements began in well USW WT-2 on June 2, 1994 using Chain \#3 and continued through the end of the year. The results of the periodic measurements on USW WT-2 are as follows:

\begin{tabular}{ccc}
\hline Date & $\begin{array}{c}\text { Measured water-tevel ahitude } \\
\text { (meters, above sea level) }\end{array}$ & Mothod \\
\hline $06-02-94$ & 730.52 & Chain \#3 \\
$07-19-94$ & 730.50 & Chain \#3 \\
$08-31-94$ & 730.54 & Chain \#3 \\
$09-27-94$ & 730.54 & Chain \#3 \\
$12-27-94$ & 730.56 & Chain \#3 \\
\hline
\end{tabular}

Water-level altitudes for well USW WT-2 ranged from 730.40 to $730.65 \mathrm{~m}$ above sea level in 1994 (fig. 3). Mean monthly water-level altitudes for January through June 1994, are listed in table 5. The mean annual water-level altitude for 1994 was $730.53 \mathrm{~m}$ above sea level. This mean altitude was $0.15 \mathrm{~m}$ lower than the mean altitude of $730.68 \mathrm{~m}$ for 1993 (Tucci, Goemaat, and Burkhardt, 1996). 


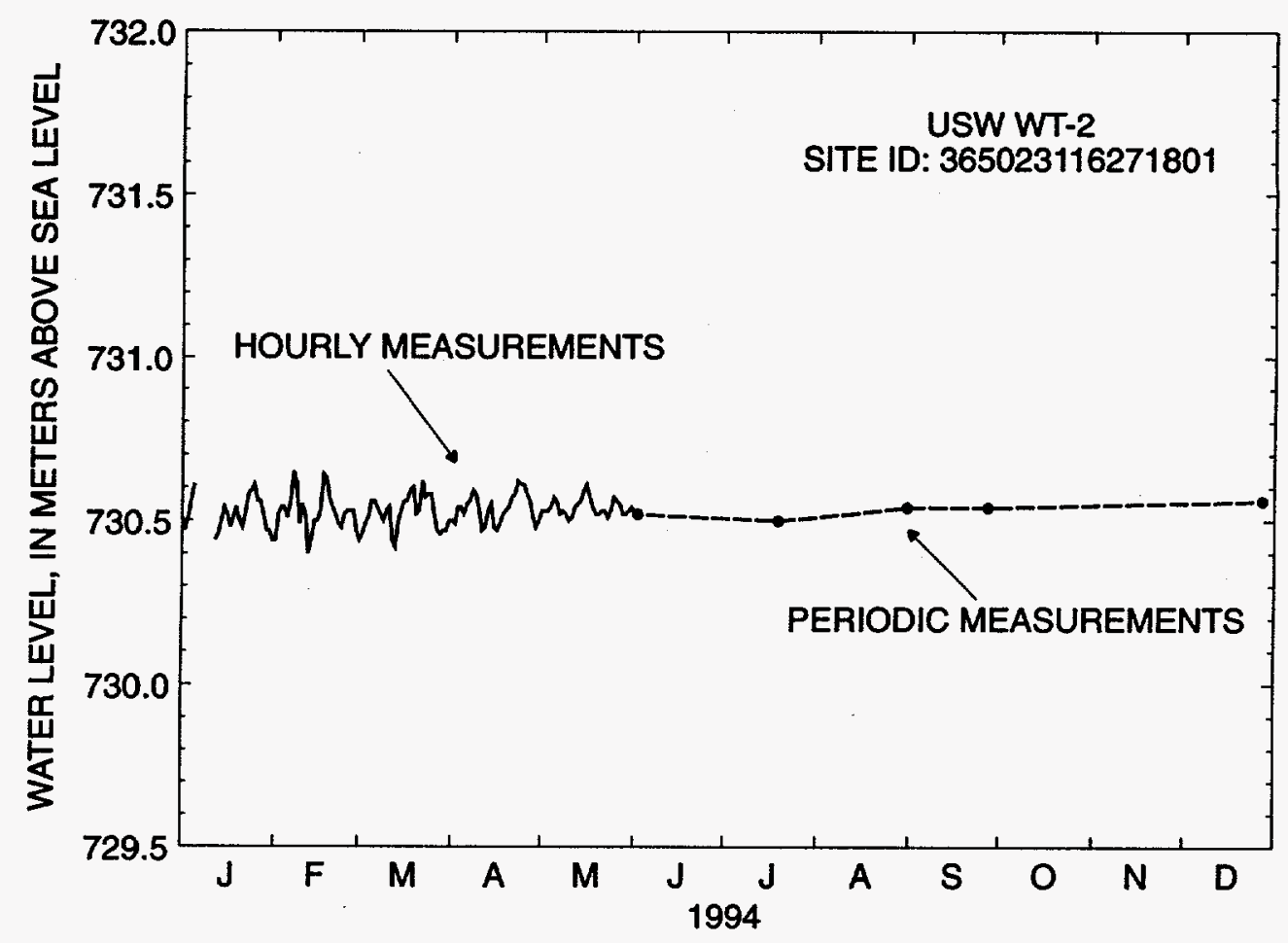

Figure 3. Water-level altitudes, 1994, for well USW WT-2.

Table 5. Mean monthly water-level altitudes, 1994, for well USW WT-2

[Monthly means were calculated regardless of the number of days of missing data. Daily means were not calculated if 6 or more consecutive hours of data were missing; ---, data not available; NA, not applicable, well not instrumented during this month]

\begin{tabular}{lcc}
\hline Month & $\begin{array}{c}\text { Water-level altitude } \\
\text { (meters, above } \\
\text { sea level) }\end{array}$ & $\begin{array}{c}\text { Number of missing } \\
\text { daily means }\end{array}$ \\
\hline January & 730.52 & 8 \\
February & 730.53 & 0 \\
March & 730.52 & 0 \\
April & 730.54 & 0 \\
May & 730.54 & 0 \\
June & 730.52 & 29 \\
July & -- & NA \\
August & -- & NA \\
September & -- & NA \\
October & -- & NA \\
November & -- & NA \\
December & -- & NA \\
\hline
\end{tabular}




\section{Well UE-25 WT \#3}

Information about the history of well UE-25 WT \#3 and about previous data from the well was obtained from various sources. These sources are: Robison (1984, 1986); Robison and others (1988); and Fenix \& Scisson, Inc. (1986a, 1987c).

Well specifications

1. Location and identification:

Latitude and longitude: $36^{\circ} 47^{\prime} 57^{\prime \prime} \mathrm{N}$.; $116^{\circ} 24^{\prime} 58^{\prime \prime} \mathrm{W}$.

Nevada State Central Zone Coordinates (m): N 227,379; E 174,768.

U.S. Geological Survey Site ID: 364757116245801.

2. Drilling and casing information:

Well started: April 29, 1983.

Well completed: May 25, 1983.

Drilling method: Rotary, using rock bits and air-foam circulating medium; core obtained

from bottom of the borehole.

Bit diameter below water level: $222 \mathrm{~mm}$.

Casing: Surface casing only, to a depth of $12 \mathrm{~m}$.

Total drilled depth: $348 \mathrm{~m}$.

3. Access to and description of interval for measuring water levels:

62-mm inside-diameter tubing that has a 3.6-m-long well screen on bottom, extending from land surface to a depth of $343 \mathrm{~m}$; saturated interval of the borehole is within the Bullfrog Tuff of the Crater Flat Group.

4. Information for calculating water-level altitude:

Reference point: Top of metal tag on well casing; altitude $1,030.11 \mathrm{~m}$ (surveyed by U.S. Geological Survey, 1984).

Measuring point: Top of access tubing, $0.155 \mathrm{~m}$.

Depth correction for borehole deviation from vertical: $0.271 \mathrm{~m}$, based on approximate depth to water of $300 \mathrm{~m}$ (1990 data).

Well UE-25 WT \#3 was measured hourly during 1994. Four calibrations of two transducers were performed during 1994. In addition, calibrations on October 18, 1993, and January 18, 1995, were used to calculate water levels for 1994 . Results of the calibrations and measured water-level altitudes obtained during the calibrations are as follows:

\begin{tabular}{ccccc}
\hline $\begin{array}{c}\text { Transducer serial } \\
\text { number }\end{array}$ & Calibration date & $\begin{array}{c}\text { Slope } \\
\text { (meters/millivolt) }\end{array}$ & $\begin{array}{c}\text { Coefficient of } \\
\text { determination }\end{array}$ & $\begin{array}{c}\text { Water-level } \\
\text { altitude' } \\
\text { (meters) }\end{array}$ \\
\hline 413600 & $10-18-93$ & 0.044 & 1.00 & 729.69 \\
413600 & $02-16-94$ & .044 & 1.00 & 729.72 \\
413600 & $06-17-94$ & .044 & 1.00 & 729.69 \\
413600 & $09-19-94$ & .044 & 1.00 & 729.66 \\
621313 & $09-19-94$ & .090 & 1.00 & 729.66 \\
621313 & $01-18-95$ & .090 & 1.00 & 729.66 \\
\hline
\end{tabular}

\footnotetext{
${ }^{1}$ Well UE-25 WT \#3: The water-level measurements made on October 18, 1993, and September 19, 1994, were made with Chain \#3. All other water-level measurements were made by tagging the water-surface with the transducer that was being calibrated.
} 
All transducer data for 1994 were considered to be valid. A daily mean was not calculated for September 19, 1994, because the calibration of the well on this date took longer than 6 hours.

Water-level altitudes for well UE-25 WT \#3 ranged from 729.60 to $729.82 \mathrm{~m}$ above sea level in 1994 (fig. 4). Mean monthly water-level altitudes are listed in table 6. The mean annual water-level altitude for 1994, was $729.70 \mathrm{~m}$ above sea level. This mean altitude was $0.02 \mathrm{~m}$ lower than the mean altitude of $729.72 \mathrm{~m}$ for 1993 (Tucci, Goemaat, and Burkhardt, 1996).

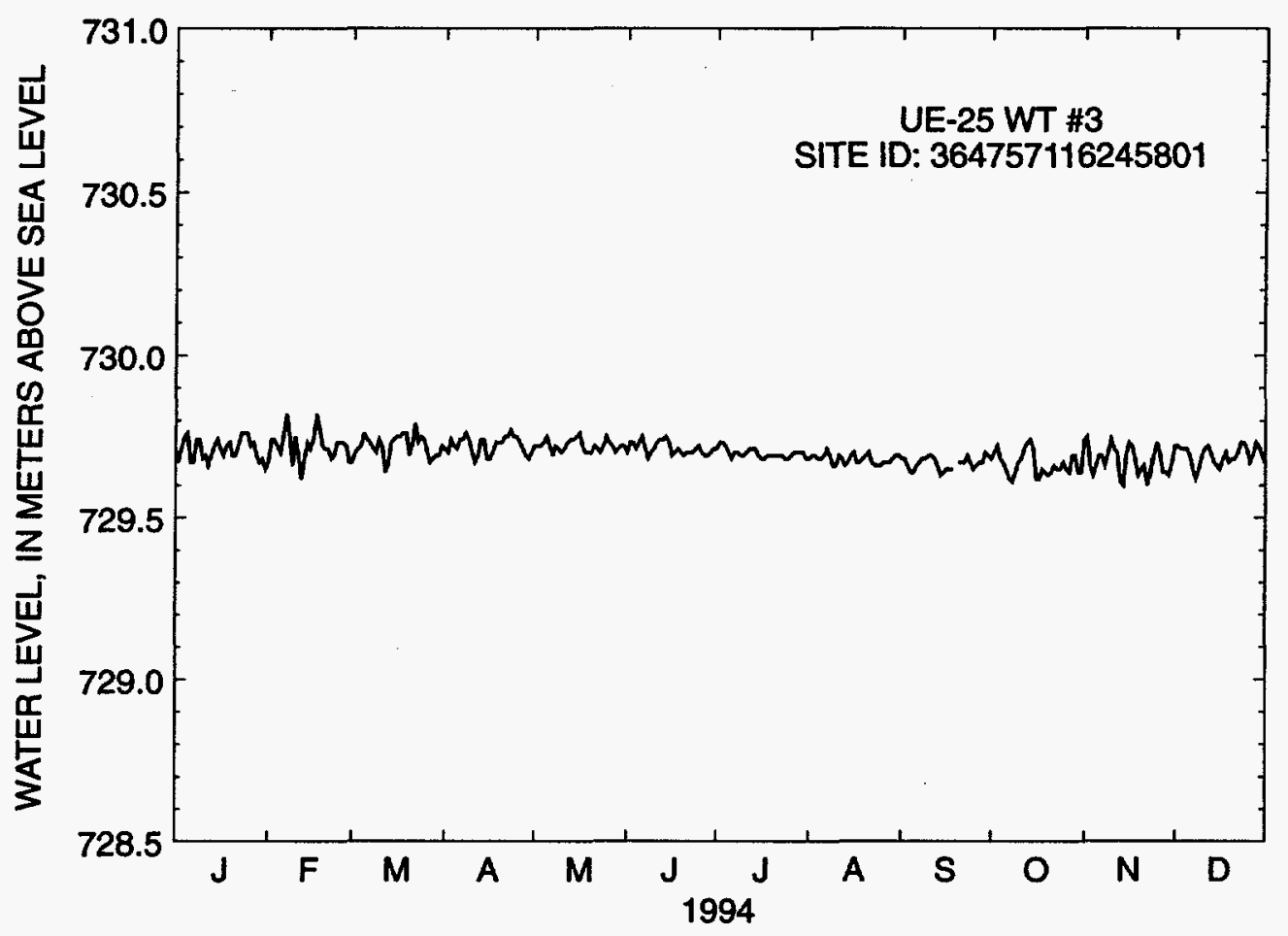

Figure 4. Water-level altitudes, 1994, for well UE-25 WT \#3.

Table 6. Mean monthly water-level altitudes, 1994, for well UE-25 WT \#3

[Monthly means were calculated regardless of the number of days of missing data. Daily means were not calculated if 6 or more consecutive hours of data were missing]

\begin{tabular}{lcc}
\hline Month & $\begin{array}{c}\text { Water-level altitude } \\
\text { (moters, above sea level) }\end{array}$ & $\begin{array}{c}\text { Number of missing } \\
\text { dally means }\end{array}$ \\
\hline January & 729.71 & 0 \\
February & 729.72 & 0 \\
March & 729.72 & 0 \\
April & 729.72 & 0 \\
May & 729.72 & 0 \\
June & 729.71 & 0 \\
July & 729.70 & 0 \\
August & 729.68 & 0 \\
September & 729.67 & 1 \\
October & 729.66 & 0 \\
November & 729.67 & 0 \\
December & 729.69 & 0 \\
\hline
\end{tabular}




\section{Well UE-25 WT \#4}

Information about the history of well UE-25 WT \#4 and about previous data from the well was obtained from various sources. These sources are: Robison (1984, 1986); Robison and others (1988); Holmes \& Narver, Inc. (written commun., 1986); and Fenix \& Scisson, Inc. (1986a, 1987c).

\section{Well specifications}

1. Location and identification:

Latitude and longitude: $36^{\circ} 51^{\prime} 40^{\prime \prime} \mathrm{N}$.; $116^{\circ} 26^{\prime} 03^{\prime \prime} \mathrm{W}$.

Nevada State Central Zone Coordinates (m): N 234,242; E 173,139.

U.S. Geological Survey Site ID: 365140116260301.

2. Drilling and casing information:

Well started: May 28, 1983.

Well completed: June 6, 1983.

Drilling method: Rotary, using rock bits and air-foam circulating medium; Core obtained from bottom of the borehole.

Bit diameter below water level: $222 \mathrm{~mm}$.

Casing: Surface casing only, to a depth of $14.6 \mathrm{~m}$.

Total drilled depth: $482 \mathrm{~m}$.

3. Access to and description of interval for measuring water levels:

62-mm inside-diameter tubing that has a 3.7-m-long well screen on the bottom; tubing and attached screen extend from land surface to a depth of $477.6 \mathrm{~m}$; saturated interval of the borehole is within the Calico Hills Formation.

4. Information for calculating water-level altitude:

Reference point: Top of metal tag on well casing, altitude 1,169.21 m (surveyed by U.S. Geological Survey, 1984).

Measuring point: Top of access tube, $0.311 \mathrm{~m}$.

Depth correction for borehole deviation from vertical: $0.454 \mathrm{~m}$, based on approximate depth to water of $438 \mathrm{~m}$ (1990 data).

Well UE-25 WT \#4 was measured periodically and hourly during 1994. Periodic measurements were made through April 14, 1994, using Chain \#3 with the following results:

\begin{tabular}{ccc}
\hline Date & $\begin{array}{c}\text { Measured water-lovel ahtitude } \\
\text { (meters, above sea level) }\end{array}$ & Mothod \\
\hline $02-03-94$ & 730.85 & Chain \#3 \\
$03-01-94$ & 730.71 & Chain \#3 \\
$03-16-94$ & 730.85 & Chain \#3 \\
$04-14-94$ & 730.86 & Chain \#3 \\
\hline
\end{tabular}


The well was instrumented with a transducer on April 14, 1994, and hourly measurements were collected for the remainder of the year. During the period of hourly measurements, three calibrations of one transducer were performed. In addition, a calibration was completed on April 6, 1995. This calibration was used to calculate water-level altitudes at the end of 1994. Results of the calibrations and measured water-level altitudes obtained during the calibration are as follows:

\begin{tabular}{|c|c|c|c|c|}
\hline $\begin{array}{l}\text { Tranaducer sertal } \\
\text { number }\end{array}$ & Calibration date & $\begin{array}{l}\text { Slope } \\
\text { (motere/millivolt) }\end{array}$ & $\begin{array}{l}\text { Coofficiont of } \\
\text { dotermination }\end{array}$ & $\begin{array}{l}\text { Water-lovel } \\
\text { altituda' } \\
\text { (motere) }\end{array}$ \\
\hline 592472 & $04-14-94$ & 0.087 & 1.00 & 730.86 \\
\hline 592472 & $08-09-94$ & .087 & 1.00 & 730.75 \\
\hline 592472 & $12-21-94$ & .087 & 1.00 & 730.77 \\
\hline 592472 & $04-06-95$ & .087 & 1.00 & 730.86 \\
\hline
\end{tabular}

Although UE-25 WT \#4 was instrumented on April 14, 1994, the collection of continuous hourly data was sporadic until April 26, 1994. Loss of data following the instrumentation of the well was due to format problems in the software of the DCP. Other problems with data collected include electronic spikes in the record that had to be removed on April 28, May 1, 5, 6, 7, 8, 9, and 28, and June 10, 1994. All other transducer data collected for 1994 were considered to be valid.

Water-level altitudes for well UE-25 WT \#4 ranged from 730.65 to $730.89 \mathrm{~m}$ above sea level in 1994 (fig. 5). Mean monthly water-level altitudes for April through December 1994, are listed in table 7. The mean annual water-level altitude for 1994 was $730.78 \mathrm{~m}$ above sea level. This mean altitude was $0.04 \mathrm{~m}$ lower the mean altitude of $730.82 \mathrm{~m}$ for 1993 (Tucci, Goemaat, and Burkhardt, 1996). 


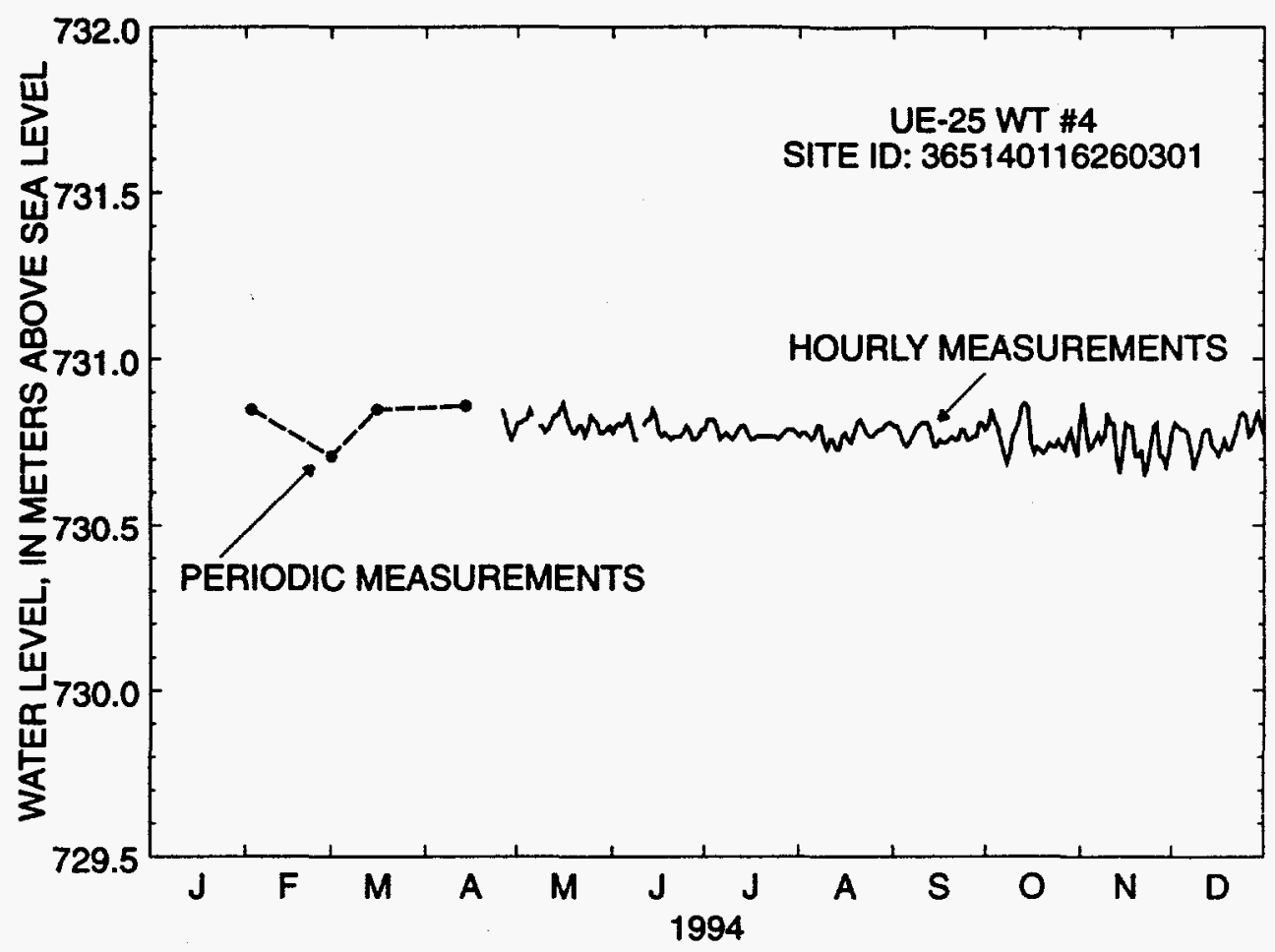

Figure 5. Water-level altitudes, 1994, for well UE-25 WT \#4.

Table 7. Mean monthly water-level altitudes, 1994, for well UE-25 WT \#4

[Monthly means were calculated regardless of the number of days of missing data. Daily means were not calculated if 6 or more consecutive hours of data were missing; ---, data not available; NA, not applicable, well not instrumented during this month]

\begin{tabular}{lcc}
\hline Month & $\begin{array}{c}\text { Water-lovel altitude } \\
\text { (motors, above } \\
\text { soa lovel) }\end{array}$ & $\begin{array}{c}\text { Number of missing } \\
\text { dally means }\end{array}$ \\
\hline January & -- & NA \\
February & - & NA \\
March & -- & NA \\
April & 730.82 & 23 \\
May & 730.81 & 1 \\
June & 730.79 & 1 \\
July & 730.78 & 0 \\
August & 730.78 & 0 \\
September & 730.77 & 0 \\
October & 730.77 & 0 \\
November & 730.75 & 0 \\
December & 730.77 & 0 \\
\hline
\end{tabular}




\section{Well UE-25 WT \#6}

Information about the history of well UE-25 WT \#6 and about previous data from the well was obtained from various sources. These sources are: Robison $(1984,1986)$; Robison and others (1988); and Fenix \& Scisson, Inc. (1986a, 1987c).

\section{Well specifications}

1. Location and identification:

Latitude and longitude: $36^{\circ} 53^{\prime} 40^{\prime \prime} \mathrm{N}$.; $116^{\circ} 26^{\prime} 46^{\prime \prime} \mathrm{W}$.

Nevada State Central Zone Coordinates (m): N 237,920; E 172,067.

U.S. Geological Survey Site ID: 365340116264601.

2. Drilling and casing information:

Well started: June 20, 1983.

Well completed: June 29, 1983.

Drilling method: Rotary, using rock bits and air-foam circulating medium; core obtained from bottom of the borehole.

Bit diameter below water level: $171 \mathrm{~mm}$.

Casing: Surface casing only, to a depth of $76.5 \mathrm{~m}$.

Total drilled depth: $383 \mathrm{~m}$.

3. Access to and description of interval for measuring water levels:

62-mm inside-diameter tubing that has a 3.6-m-long well screen on bottom, extending from land surface to a depth of $372 \mathrm{~m}$; saturated interval of the borehole is within the Calico Hills Formation.

4. Information for calculating water-level altitude:

Reference point: Top of metal tag on well casing; altitude 1,314.78 $\mathrm{m}$ (surveyed by U.S. Geological Survey, 1984).

Measuring point: Top of access tube, $0.463 \mathrm{~m}$.

Depth correction for borehole deviation from vertical: $0.204 \mathrm{~m}$, based on approximate depth to water of $280 \mathrm{~m}$ (1990 data).

Well UE-25 WT \#6 was measured periodically during 1994 . All measurements were made with Chain \#3 with the following results: 


\begin{tabular}{ccc}
\hline Date & $\begin{array}{c}\text { Measured water-level altitude } \\
\text { (moters, above sea level) }\end{array}$ & Method \\
\hline $01-31-94$ & $1,034.43$ & Chain \#3 \\
$02-28-94$ & $1,034.51$ & Chain \#3 \\
$03-28-94$ & $1,034.48$ & Chain \#3 \\
$04-29-94$ & $1,034.49$ & Chain \#3 \\
$05-12-94$ & $1,034.54$ & Chain \#3 \\
$06-07-94$ & $1,034.50$ & Chain \#3 \\
$07-15-94$ & $1,034.46$ & Chain \#3 \\
$08-15-94$ & $1,034.44$ & Chain \#3 \\
$09-28-94$ & $1,034.43$ & Chain \#3 \\
$10-13-94$ & $1,034.52$ & Chain \#3 \\
$11-03-94$ & $1,034.56$ & Chain \#3 \\
$12-13-94$ & $1,034.47$ & Chain \#3 \\
\hline
\end{tabular}

Water-level altitudes for well UE-25 WT \#6 ranged from 1,034.43 to 1,034.56 m above sea level in 1994 (fig. 6). The mean annual water-level altitude for 1994 was $1,034.49 \mathrm{~m}$ above sea level. This mean altitude was $0.14 \mathrm{~m}$ higher than the mean altitude of $1,034.35 \mathrm{~m}$ for 1993 (Tucci, Goemaat, and Burkhardt, 1996).

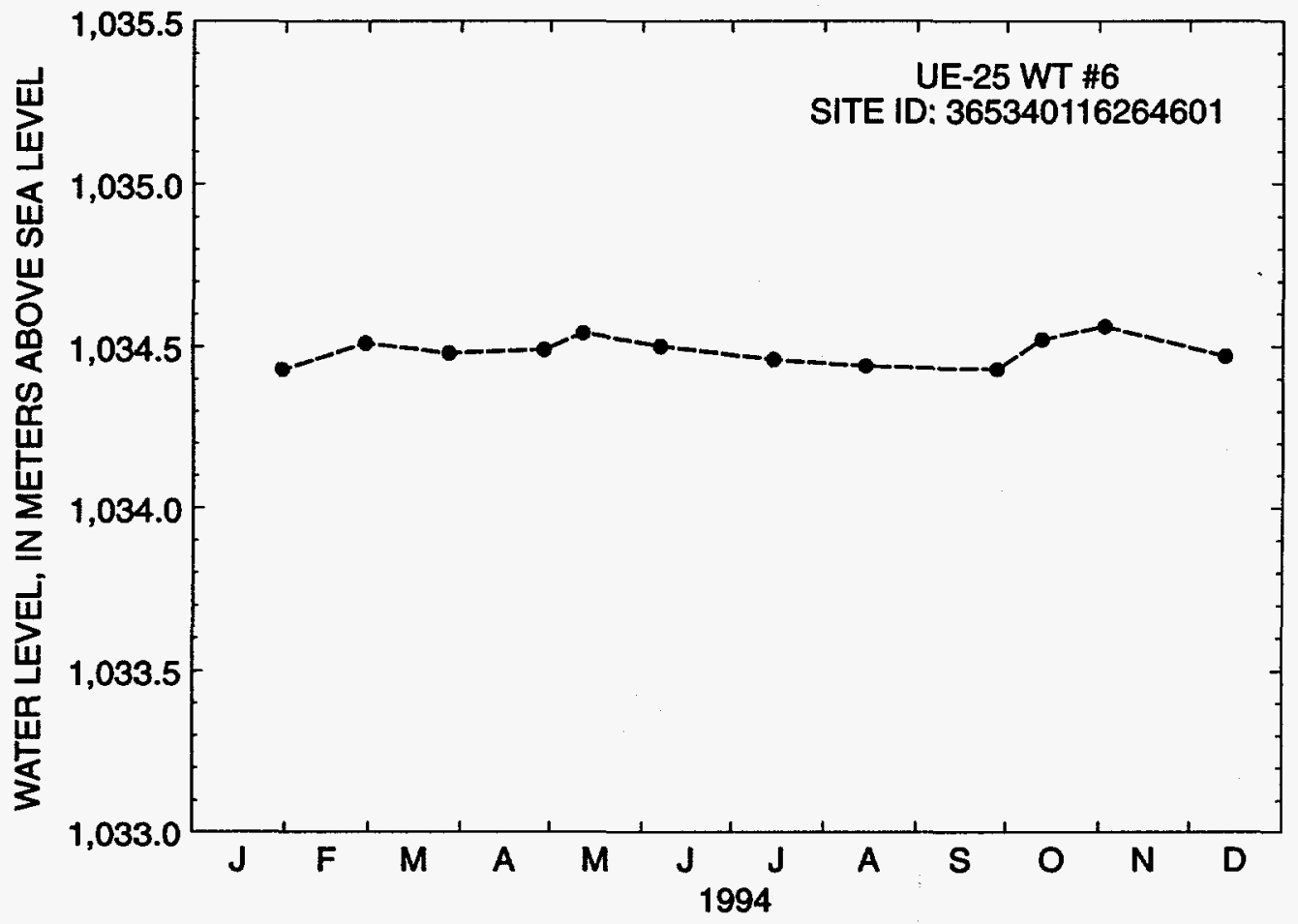

Figure 6. Water-level altitudes, 1994, for well UE-25 WT \#6. 


\section{Well USW WT-7}

Information about the history or well USW WT-7 and about previous data from the well was obtained from various sources. These sources are: Robison (1984, 1986); Robison and others (1988); Holmes \& Narver, Inc. (written commun., 1986); and Fenix \& Scisson, Inc. (1986a, 1987c).

Well specifications

1. Location and identification:

Latitude and longitude: $36^{\circ} 49^{\prime} 33^{\prime \prime} \mathrm{N}$.; $116^{\circ} 28^{\prime} 57^{\prime \prime} \mathrm{W}$.

Nevada State Central Zone Coordinates (m): N 230,298; E 168,826.

U.S. Geological Survey Site ID: 364933116285701.

2. Drilling and casing information:

Well started: July 19, 1983.

Well completed: July 26, 1983.

Drilling method: Rotary, using rock bits and air-foam circulating medium; core obtained from bottom of the borehole.

Bit diameter below water level: $222 \mathrm{~mm}$.

Casing: Surface casing only, to a depth of $15.8 \mathrm{~m}$.

Total drilled depth: $491 \mathrm{~m}$.

3. Access to and description of interval for measuring water levels:

62-mm inside-diameter tubing that has a 3.7-m-long well screen on the bottom; tubing and attached screen extend from land surface to a depth of $481.3 \mathrm{~m}$; saturated interval of the borehole is within the Topopah Spring Tuff of the Paintbrush Group and the Prow Pass Tuff of the Crater Flat Group.

4. Information for calculating water-level altitude:

Reference point: Top of metal tag on well casing, altitude $1,196.88 \mathrm{~m}$ (surveyed by U.S. Geological Survey, 1984).

Measuring point: Top of access tube, $0.302 \mathrm{~m}$.

Depth correction for borehole deviation from vertical: $0.034 \mathrm{~m}$, based on approximate depth to water of $421 \mathrm{~m}$ (1990 data).

Well USW WT-7 was measured periodically during 1994. All measurements were made with Chain \#3 with the following results: 


\begin{tabular}{ccc}
\hline Date & $\begin{array}{c}\text { Moasured water-lovel attitude } \\
\text { (moters, above soa lovel) }\end{array}$ & Mothod \\
\hline $02-01-94$ & 775.86 & Chain \#3 \\
$02-25-94$ & 775.91 & Chain \#3 \\
$03-29-94$ & 775.88 & Chain \#3 \\
$04-22-94$ & 775.90 & Chain \#3 \\
$05-24-94$ & 775.88 & Chain \#3 \\
$06-08-94$ & 775.84 & Chain \#3 \\
$07-18-94$ & 775.87 & Chain \#3 \\
$08-25-94$ & 775.88 & Chain \#3 \\
$09-22-94$ & 775.90 & Chain \#3 \\
$10-26-94$ & 775.88 & Chain \#3 \\
$11-22-94$ & 775.80 & Chain \#3 \\
$12-22-94$ & 775.94 & Chain \#3 \\
\hline
\end{tabular}

Water-level altitudes for well USW WT-7 ranged from 775.80 to $775.94 \mathrm{~m}$ above sea level in 1994 (fig. 7). The mean annual water-level altitude for 1994 was $775.88 \mathrm{~m}$ above sea level. This mean altitude was the same as the mean altitude of $775.88 \mathrm{~m}$ for 1993 (Tucci, Goemaat, and Burkhardt, 1996).

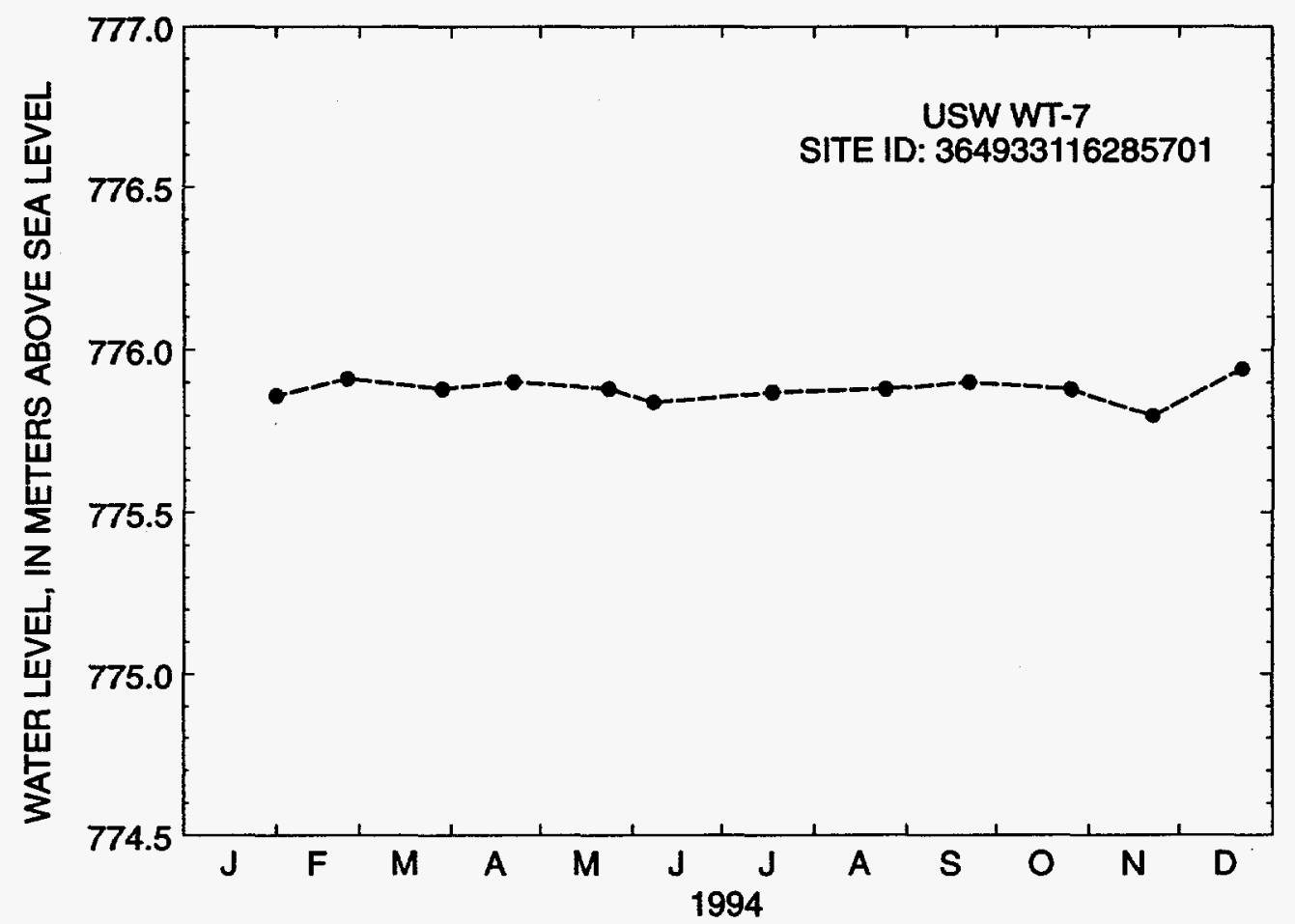

Figure 7. Water-level altitudes, 1994, for well USW WT-7. 


\section{Well USW WT-10}

Information about the history of well USW WT-10 and about previous data from the well was obtained from various sources. These sources are: Robison (1984, 1986); Robison and others (1988); Holmes \& Narver, Inc. (written commun., 1986); and Fenix \& Scisson, Inc. (1986a, 1987c).

\section{Well specifications}

\section{Location and identification:}

Latitude and longitude: $36^{\circ} 48^{\prime} 25^{\prime \prime} \mathrm{N}$.; $116^{\circ} 29^{\prime} 05^{\prime \prime} \mathrm{W}$.

Nevada State Central Zone Coordinates (m): N 228,225; E 168,646.

U.S. Geological Survey Site ID: 364825116290501.

2. Drilling and casing information:

Well started: July 26, 1983.

Well completed: August 2, 1983.

Drilling method: Rotary, using rock bits and air-foam circulating medium; core obtained from bottom of the borehole.

Bit diameter below water level: $222 \mathrm{~mm}$.

Casing: Surface casing only, to a depth of $34.7 \mathrm{~m}$.

Total drilled depth: $431 \mathrm{~m}$.

3. Access to and description of interval for measuring water levels:

62-mm inside-diameter tubing that has a 3.7-m-long well screen on the bottom; tubing and attached screen extend from land surface to a depth of $402.6 \mathrm{~m}$; saturated interval of the borehole is within the Topopah Spring Tuff of the Paintbrush Group.

4. Information for calculating water-level altitude:

Reference point: Top of metal tag on well casing, altitude $1,123.40 \mathrm{~m}$ (surveyed by U.S. Geological Survey; 1984).

Measuring point: Top of access tube, $0.314 \mathrm{~m}$.

Depth correction for borehole deviation from vertical: $0.030 \mathrm{~m}$, based on approximate depth to water of $347 \mathrm{~m}$ (1990 data).

Well USW WT-10 was measured periodically and hourly during 1994. Periodic measurements were made through June 16, 1994, using Chain \#3 with the following results:

\begin{tabular}{ccc}
\hline Date & $\begin{array}{c}\text { Measured water-tevel altitude } \\
\text { (meters, above sea level) }\end{array}$ & Method \\
\hline $02-01-94$ & 776.02 & Chain \#3 \\
$02-25-94$ & 776.10 & Chain \#3 \\
$03-29-94$ & 776.07 & Chain \#3 \\
$04-22-94$ & 776.14 & Chain \#3 \\
$05-24-94$ & 776.09 & Chain \#3 \\
$06-08-94$ & 776.16 & Chain \#3 \\
$06-16-94$ & 776.07 & Chain \#3 \\
\hline
\end{tabular}


The well was instrumented with a transducer on June 16,1994, and hourly measurements collected for the remainder of the year. During the period of hourly measurements, three calibrations of one transducer were performed. In addition, a calibration was completed on April 5, 1995. This calibration was used to calculate water-level altitudes at the end of 1994. Results of the calibrations and measured waterlevel altitudes obtained during the calibration are as follows:

\begin{tabular}{rlccc}
\hline $\begin{array}{c}\text { Transducer serial } \\
\text { number }\end{array}$ & Callbration date & $\begin{array}{c}\text { Slope } \\
\text { (meters/millivolt) }\end{array}$ & $\begin{array}{c}\text { Coefficient of } \\
\text { determination }\end{array}$ & $\begin{array}{c}\text { Water-level } \\
\text { altitude' } \\
\text { (meters) }\end{array}$ \\
\hline 592476 & $06-16-94$ & 0.087 & 1.00 & 776.07 \\
592476 & $08-10-94$ & .088 & 1.00 & 776.03 \\
592476 & $12-22-94$ & .089 & 1.00 & 776.07 \\
592476 & $04-05-95$ & .088 & 1.00 & 776.12 \\
\hline \\
'Well USW WT-10: The water-level measurement made on June 16, 1994, was made with Chain \#3. All \\
other water-level measurements were made by tagging the water-surface with the transducer that was being \\
calibrated.
\end{tabular}

All transducer data collected for USW WT-10 for 1994 were considered to be valid with no lost record from June 16, 1994, through the end of the year.

Water-level altitudes for well USW WT-10 ranged from 776.02 to $776.32 \mathrm{~m}$ above sea level in 1994 (fig. 8). Mean monthly water-level altitudes for June through December 1994 are listed in table 8. The mean annual water-level altitude for 1994 was $776.15 \mathrm{~m}$ above sea level. This mean altitude was $0.04 \mathrm{~m}$ higher than the mean altitude of $776.11 \mathrm{~m}$ for 1993 (Tucci, Goemaat, and Burkhardt, 1996). 


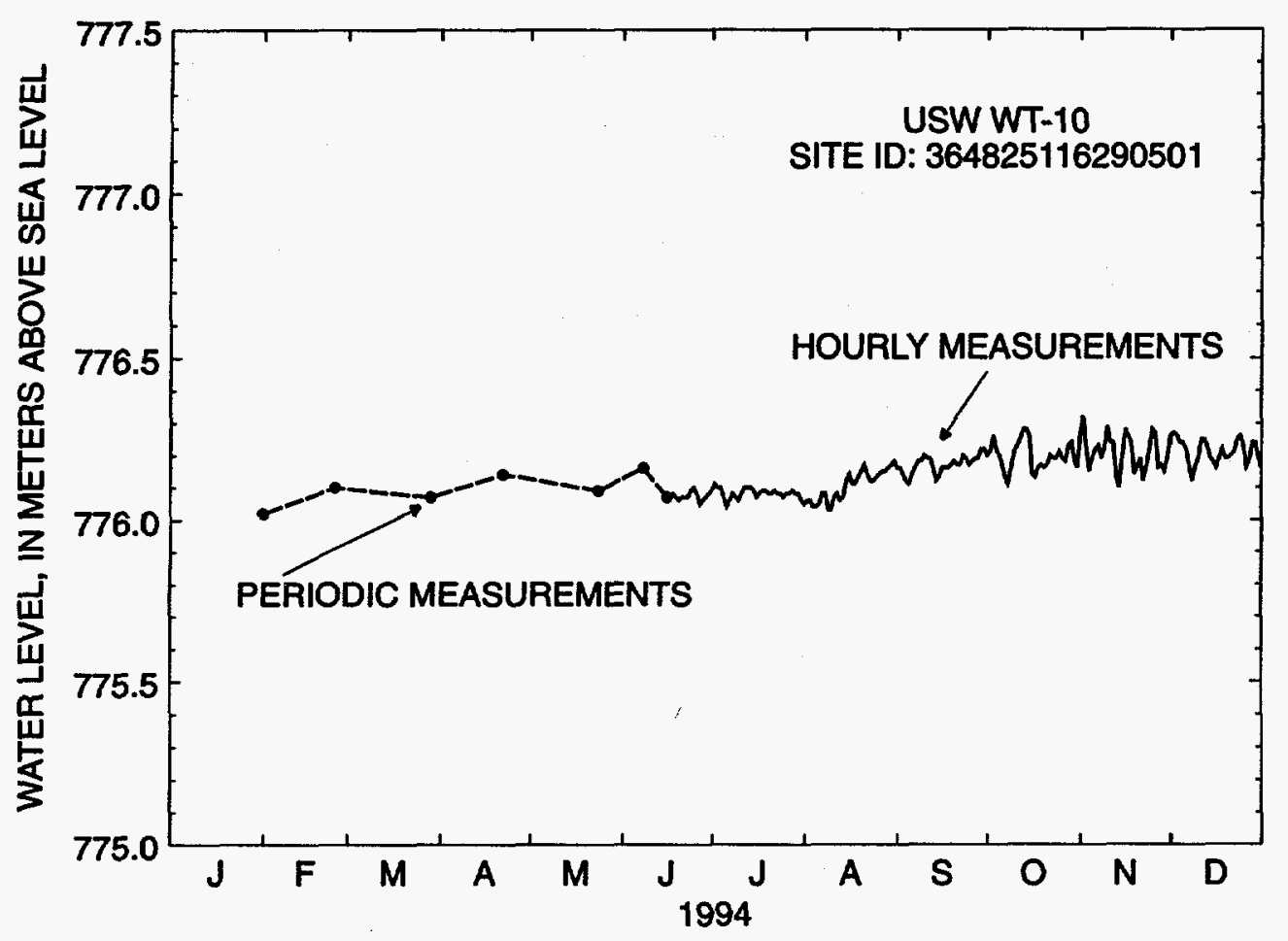

Figure 8. Water-level altitudes, 1994, for well USW WT-10.

Table 8. Mean monthly water-level altitudes, 1994, for well USW WT-10

[Monthly means were calculated regardless of the number of days of missing data. Daily means were not calculated if 6 or more consecutive hours of data were missing;

--- , data not available; NA, not applicable, well not instrumented during this month]

\begin{tabular}{lcc}
\hline Month & $\begin{array}{c}\text { Water-level altitude } \\
\text { (meters, above } \\
\text { sea level) }\end{array}$ & $\begin{array}{c}\text { Number of missing } \\
\text { dally means }\end{array}$ \\
\hline January & --- & NA \\
February & --- & NA \\
March & --- & NA \\
April & -- & NA \\
May & --- & NA \\
June & 776.07 & 16 \\
July & 776.08 & 0 \\
August & 776.10 & 0 \\
September & 776.17 & 0 \\
October & 776.20 & 0 \\
November & 776.21 & 0 \\
December & 776.21 & 0 \\
\hline
\end{tabular}




\section{Well USW WT-11}

Information about the history of well USW WT-11 and about previous data from the well was obtained from various sources. These sources are: Robison $(1984,1986)$; Robison and others (1988); and Fenix \& Scisson, Inc. (1986a, 1987c).

\section{Well specifications}

1. Location and identification:

Latitude and longitude: $36^{\circ} 46^{\prime} 49^{\prime \prime} \mathrm{N}$.; $116^{\circ} 28^{\prime} 02^{\prime \prime} \mathrm{W}$.

Nevada State Central Zone Coordinates (m): N 225,269; E 170,193.

U.S. Geological Survey Site ID: 364649116280201.

2. Drilling and casing information:

Well started: August 3, 1983.

Well completed: August 9, 1983.

Drilling method: Rotary, using rock bits and air-foam circulating medium; core obtained

from bottom of the borehole.

Bit diameter below water level: $222 \mathrm{~mm}$.

Casing: Surface casing only, to a depth of $14 \mathrm{~m}$.

Total drilled depth: $441 \mathrm{~m}$.

3. Access to and description of interval for measuring water levels:

62-mm inside-diameter tubing that has a 3.6-m-long well screen on bottom, extending from land surface to a depth of $416 \mathrm{~m}$; saturated interval of the borehole is within the Topopah Spring Tuff of the Paintbrush Group and the Calico Hills Formation.

4. Information for calculating water-level altitude:

Reference point: Top of metal tag on well casing; altitude 1,094.11 m (surveyed by U.S. Geological Survey, 1984).

Measuring point: Top of access tube, $0.311 \mathrm{~m}$.

Depth correction for borehole deviation from vertical: $0.116 \mathrm{~m}$, based on approximate depth to water of $363 \mathrm{~m}$ (1990 data).

Well USW WT-11 was measured periodically and hourly during 1994. Hourly measurements were made until June 15, 1994; the day the transducer was removed from the well. During the period of hourly measurements two calibrations of one transducer were performed. In addition, a calibration was completed on October 6, 1993. This calibration was used to calculate water-level altitudes at the beginning of 1994. Results of the calibration and measured water-level altitudes obtained during the calibration are as follows:

\begin{tabular}{ccccc}
\hline $\begin{array}{c}\text { Transducer serlal } \\
\text { number }\end{array}$ & Calibration date & $\begin{array}{c}\text { Slope } \\
\text { (meters/millivolt) }\end{array}$ & $\begin{array}{c}\text { Coefficlent of } \\
\text { determination }\end{array}$ & $\begin{array}{c}\text { Water-level } \\
\text { attitude } \\
\text { (meters) }\end{array}$ \\
\hline 506101 & $10-06-93$ & 0.086 & 1.00 & 730.72 \\
506101 & $02-01-94$ & .087 & 1.00 & 730.63 \\
506101 & $06-15-94$ & .086 & 1.00 & 730.66 \\
\hline
\end{tabular}

'Well USW WT-11: The water-level measurement made on June 15, 1994, was made with Chain \#3. All other water-level measurements were made by tagging the water-surface with the transducer that was being calibrated. 
Transducer data collected for USW WT-11 for 1994 were generally considered to be valid. However, due to electronic problems some data were lost. No data were collected for February 27 and 28 and March 1, 1994, and only partial data were collected for February 26 and March 2, 1994, because the transducer excitation was not working.

Periodic measurements began on well USW WT-11 on June 15, 1994, using Chain \#3 and continued monthly through the end of the year. The results of the periodic measurements are as follows:

\begin{tabular}{ccc}
\hline Date & $\begin{array}{c}\text { Mossured water-lovel altitude } \\
\text { (motors, above son level) }\end{array}$ & Mothod \\
\hline $06-15-94$ & 730.66 & Chain \#3 \\
$07-29-94$ & 730.68 & Chain \#3 \\
$08-25-94$ & 730.73 & Chain \#3 \\
$09-22-94$ & 730.63 & Chain \#3 \\
$10-26-94$ & 730.67 & Chain \#3 \\
$11-22-94$ & 730.56 & Chain \#3 \\
$12-22-94$ & 730.65 & Chain \#3 \\
\hline
\end{tabular}

Water-level altitudes for well USW WT-11 ranged from 730.56 to $730.84 \mathrm{~m}$ above sea level in 1994 (fig. 9). Mean monthly water-level altitudes for January through June 1994, are listed in table 9. The mean annual water-level altitude for 1994 was $730.68 \mathrm{~m}$ above sea level. This mean altitude was $0.01 \mathrm{~m}$ lower than the mean altitude of $730.69 \mathrm{~m}$ for 1993 (Tucci, Goemaat, and Burkhardt, 1996). 


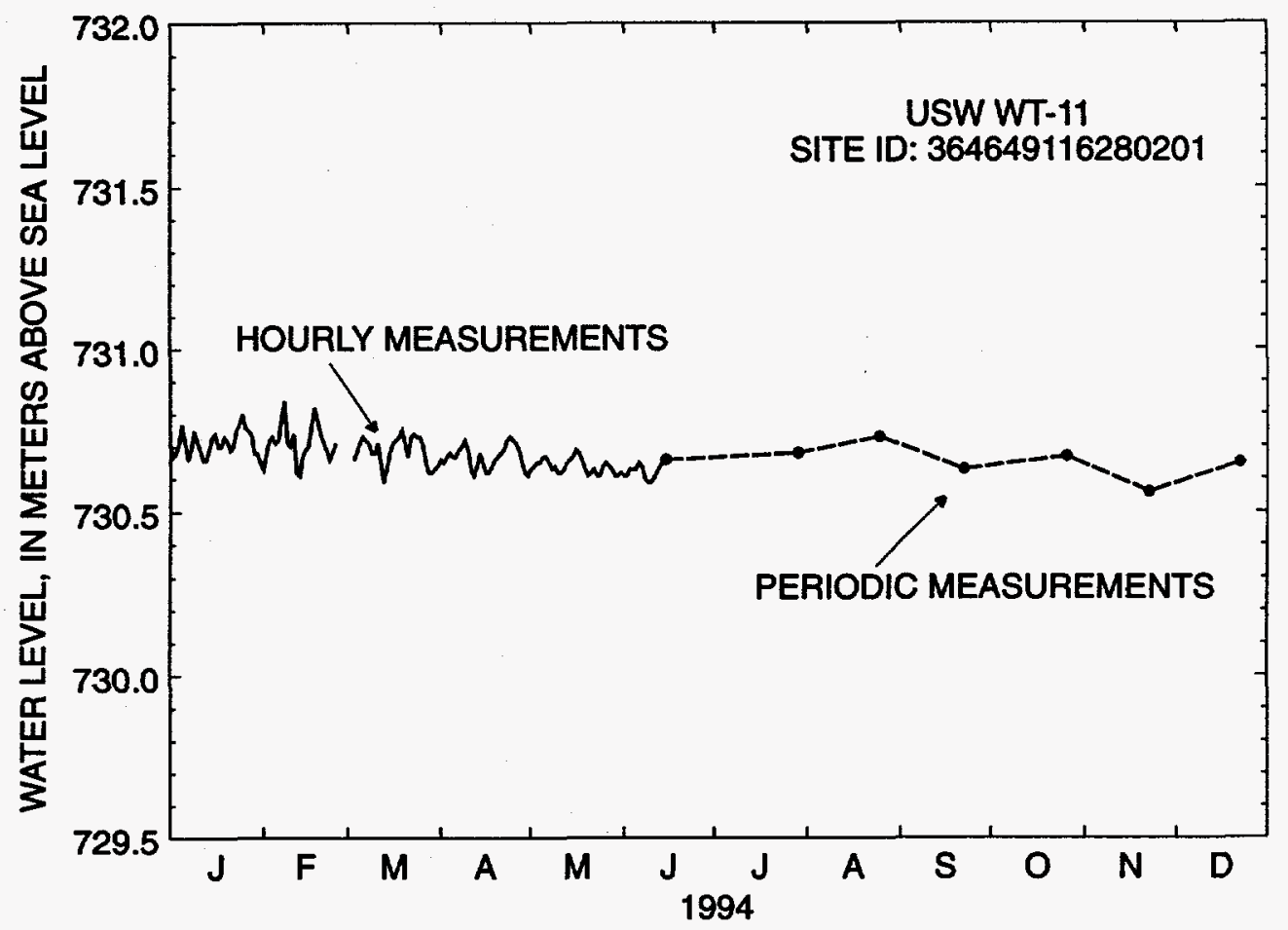

Figure 9. Water-level altitudes, 1994, for well USW WT-11.

Table 9. Mean monthly water-level altitudes, 1994, for well USW WT-11

[Monthly means were calculated regardless of the number of days of missing data. Daily means were not calculated if 6 or more consecutive hours of data were missing; ---, data not available; NA, not applicable, well not instrumented during this month]

\begin{tabular}{lcc}
\hline Month & $\begin{array}{c}\text { Water-level altitude } \\
\text { (moters, above } \\
\text { sea level) }\end{array}$ & $\begin{array}{c}\text { Number of missing } \\
\text { daily means }\end{array}$ \\
\hline January & 730.71 & 0 \\
February & 730.71 & 3 \\
March & 730.69 & 2 \\
April & 730.67 & 0 \\
May & 730.64 & 0 \\
June & 730.62 & 16 \\
July & -- & NA \\
August & --- & NA \\
September & --- & NA \\
October & -- & NA \\
November & --- & NA \\
December & --- & NA \\
\hline
\end{tabular}




\section{Well UE-25 WT \#12}

Information about the history of well UE-25 WT \#12 and about previous data from the well was obtained from various sources. These sources are: Robison $(1984,1986)$; Robison and others (1988); Holmes \& Narver, Inc. (written commun., 1986); and Fenix \& Scisson, Inc. (1986a, 1987c).

Well specifications

1. Location and identification:

Latitude and longitude: $36^{\circ} 46^{\prime} 56^{\prime \prime} \mathrm{N}$.; $116^{\circ} 26^{\prime} 16^{\prime \prime} \mathrm{W}$.

Nevada State Central Zone Coordinates (m): N 225,468; E 172,825.

U.S. Geological Survey Site ID: 364656116261601.

2. Drilling and casing information:

Well started: August 11, 1983.

Well completed: August 16, 1983.

Drilling method: Rotary, using rock bits and air-foam circulating medium; core obtained from bottom of the borehole.

Bit diameter below water level: $222 \mathrm{~mm}$.

Casing: Surface casing only, to a depth of $21.3 \mathrm{~m}$.

Total drilled depth: $399 \mathrm{~m}$.

3. Access to and description of interval for measuring water levels:

62-mm inside-diameter tubing that has a 3.7-m-long well screen on the bottom; tubing and attached screen extend from land surface to a depth of $388.9 \mathrm{~m}$; saturated interval of the borehole is within the Topopah Spring Tuff of the Paintbrush Group and the Calico Hills Formation.

4. Information for calculating water-level altitude:

Reference point: Top of metal tag on well casing, altitude $1,074.74 \mathrm{~m}$ (surveyed by U.S. Geological Survey, 1984).

Measuring point: Top of access tube, $0.305 \mathrm{~m}$.

Depth correction for borehole deviation from vertical: $0.183 \mathrm{~m}$, based on approximate depth to water of $345 \mathrm{~m}$ (1990 data).

Well UE-25 WT\#12 was measured periodically during 1994. All measurements were made with Chain \#3 with the following results: 


\begin{tabular}{ccc}
\hline Date & $\begin{array}{c}\text { Moasured water-fovel altitude } \\
\text { (moters, above sea level) }\end{array}$ & Mothod \\
\hline $02-02-94$ & 729.50 & Chain \#3 \\
$03-01-94$ & 729.37 & Chain \#3 \\
$03-24-94$ & 729.45 & Chain \#3 \\
$05-02-94$ & 729.45 & Chain \#3 \\
$05-27-94$ & 729.42 & Chain \#3 \\
$06-24-94$ & 729.43 & Chain \#3 \\
$07-27-94$ & 729.43 & Chain \#3 \\
$08-31-94$ & 729.43 & Chain \#3 \\
$09-30-94$ & 729.48 & Chain \#3 \\
$10-27-94$ & 729.41 & Chain \#3 \\
$11-29-94$ & 729.40 & Chain \#3 \\
$12-29-94$ & 729.44 & Chain \#3 \\
\hline
\end{tabular}

Water-level altitudes for well UE-25 WT \#12 ranged from 729.37 to $729.50 \mathrm{~m}$ above sea level in 1994 (fig. 10) The mean annual water-level altitude for 1994 was $729.43 \mathrm{~m}$ above sea level. This mean altitude was $0.01 \mathrm{~m}$ higher than the mean altitude of $729.42 \mathrm{~m}$ for 1993 (Tucci, Goemaat, and Burkhardt, 1996).

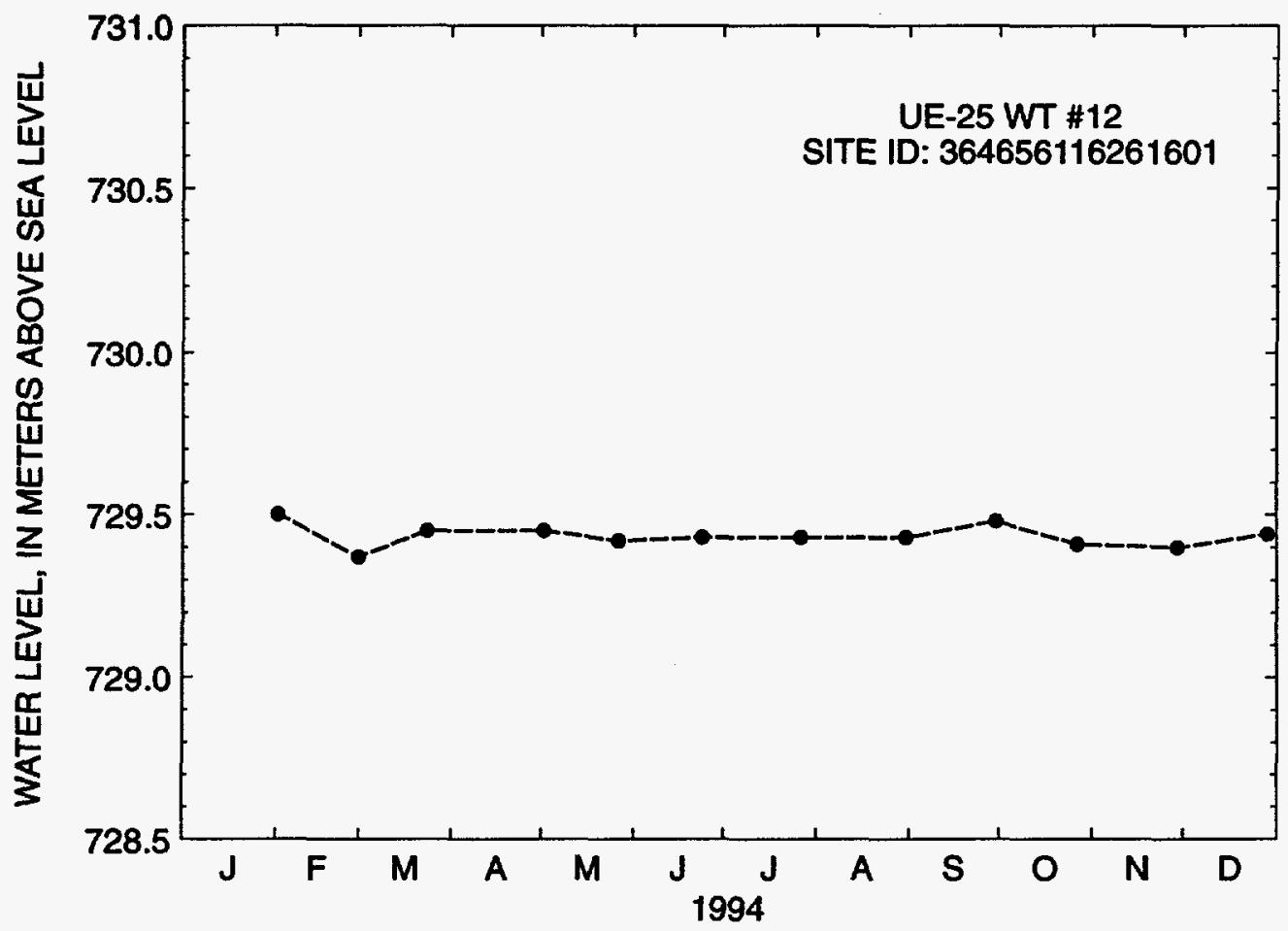

Figure 10. Water-level altitudes, 1994, for well UE-25 WT \#12. 


\section{Well UE-25 WT \#13}

Information about the history of well UE-25 WT \#13 and about previous data from the well was obtained from various sources. These sources are: Robison (1984, 1986); Robison and others (1988); and Fenix \& Scisson, Inc. (1986a, 1987c).

\section{Well specifications}

1. Location and identification:

Latitude and longitude: $36^{\circ} 49^{\prime} 43^{\prime \prime} \mathrm{N}$.; $116^{\circ} 23^{\prime} 51^{\prime \prime} \mathrm{W}$.

Nevada State Central Zone Coordinates (m): N 230,647; E 176,405.

U.S. Geological Survey Site ID: 364945116235001.

2. Drilling and casing information:

Well started: June 29, 1983.

Well completed: July 7, 1983.

Drilling method: Rotary, using rock bits and air-foam circulating medium; core obtained from bottom of the borehole.

Bit diameter below water level: $222 \mathrm{~mm}$.

Casing: Surface casing only, to a depth of $68 \mathrm{~m}$.

Total drilled depth: $354 \mathrm{~m}$.

3. Access to and description of interval for measuring water levels:

62-mm inside-diameter tubing that has a 3.6-m-long well screen on bottom, extending from land surface to a depth of $346 \mathrm{~m}$; saturated interval of the borehole is within the Topopah Spring Tuff of the Paintbrush Group.

4. Information for calculating water-level altitude:

Reference point: Top of metal tag on well casing; altitude 1,032.51 m (surveyed by U.S. Geological Survey, 1984).

Measuring point: Top of access tube, $0.305 \mathrm{~m}$.

Depth correction for borehole deviation from vertical: $0.012 \mathrm{~m}$, based on approximate depth to water of $304 \mathrm{~m}$ (1990 data).

Well UE-25 WT \#13 was measured periodically and hourly during 1994 . Hourly measurements were made until June 21, 1994; the day the transducer was removed from the well. During the period of hourly measurements four calibrations of two transducers were performed. In addition, a calibration was completed on September 9, 1993. This calibration was used to calculate water-level altitudes at the beginning of 1994. Results of the calibration and measured water-level altitudes obtained during the calibration are as follows: 


\begin{tabular}{ccccc}
\hline $\begin{array}{c}\text { Transducer serial } \\
\text { number }\end{array}$ & Calibration date & $\begin{array}{c}\text { Slope } \\
\text { (motora/millivolt) }\end{array}$ & $\begin{array}{c}\text { Cocificlent of } \\
\text { determination }\end{array}$ & $\begin{array}{c}\text { Water-tevel } \\
\text { althuda' } \\
\text { (meters) }\end{array}$ \\
\hline 465824 & $09-30-93$ & 0.089 & 1.00 & 729.09 \\
465824 & $01-27-94$ & .089 & 1.00 & 729.15 \\
465824 & $02-08-94$ & .086 & 1.00 & 729.26 \\
592473 & $02-08-94$ & .088 & 1.00 & 729.26 \\
592473 & $06-21-94$ & .087 & 1.00 & 729.10 \\
\hline
\end{tabular}

${ }^{1}$ Well UE-25 WT \#13: The water-level measurement made on September 30, 1993, was made by tagging the water-surface with the transducer that was being calibrated. All other water-level measurements were made with Chain \#3.

All transducer data collected for UE-25 WT \#13 for 1994 were considered to be valid.

Periodic measurements began on well UE-25 WT \#13 on June 21, 1994 using Chain \#3 and continued monthly through the end of the year. The results of the periodic measurements on UE-25 WT \#13 are as follows:

\begin{tabular}{ccc}
\hline Date & $\begin{array}{c}\text { Measured water-tevel altitude } \\
\text { (moters, above sea lovel) }\end{array}$ & Method \\
\hline $06-21-94$ & 729.10 & Chain \#3 \\
$07-15-94$ & 729.13 & Chain \#3 \\
$08-15-94$ & 729.15 & Chain \#3 \\
$09-28-94$ & 729.12 & Chain \#3 \\
$10-13-94$ & 729.26 & Chain \#3 \\
$11-03-94$ & 729.17 & Chain \#3 \\
$12-29-94$ & 729.17 & Chain \#3 \\
\hline
\end{tabular}

Water-level altitudes for well UE-25 WT \#13 ranged from 729.02 to $729.34 \mathrm{~m}$ above sea level in 1994 (fig. 11). Mean monthly water-level altitudes for January through June 1994 are listed in table 10. The mean annual water-level altitude for 1994 was $729.17 \mathrm{~m}$ above sea level. This mean altitude was $0.06 \mathrm{~m}$ higher than the mean altitude of $729.11 \mathrm{~m}$ of 1993 (Tucci, Goemaat, and Burkhardt, 1996). 


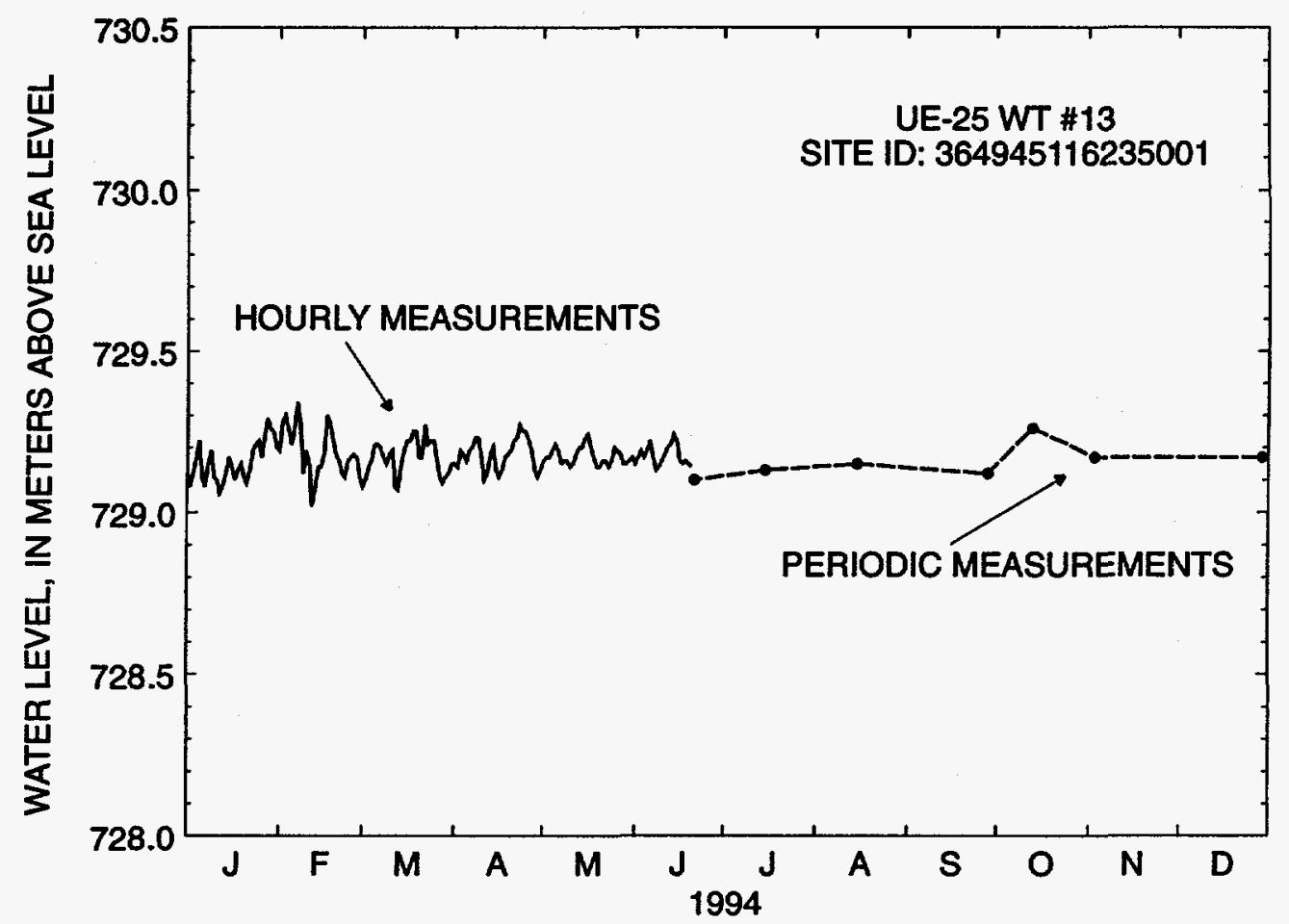

Figure 11. Water-level altitudes, 1994, for well UE-25 WT \#13.

Table 10. Mean monthly water-level altitudes, 1994, for well UE-25 WT \#13

[Monthly means were calculated regardless of the number of days of missing data.

Daily means were not calculated if 6 or more consecutive hours of data were missing;

.-., data not available; NA, not applicable, well not instrumented during this month]

\begin{tabular}{llc}
\hline Month & $\begin{array}{c}\text { Water-level altitude } \\
\text { (meters, above } \\
\text { sea level) }\end{array}$ & $\begin{array}{c}\text { Number of missing } \\
\text { daily moans }\end{array}$ \\
\hline January & 729.15 & 0 \\
February & 729.19 & 0 \\
March & 729.17 & 0 \\
April & 729.18 & 0 \\
May & 729.17 & 0 \\
June & 729.17 & 10 \\
July & -- & NA \\
August & -- & NA \\
September & -- & NA \\
October & --- & NA \\
November & --- & NA \\
December & --- & NA \\
\hline
\end{tabular}




\section{Well UE-25 WT \#14}

Information about the history of well UE-25 WT \#14 and about previous data from the well was obtained from various sources. These sources are: Robison (1984, 1986); Robison and others (1988); Holmes \& Narver, Inc. (written commun., 1986); and Fenix \& Scisson, Inc. (1986a, 1987c).

Well specifications

1. Location and identification:

Latitude and longitude: $36^{\circ} 50^{\prime} 32^{\prime \prime} \mathrm{N}$.; $116^{\circ} 24^{\prime} 35^{\prime \prime} \mathrm{W}$.

Nevada State Central Zone Coordinates (m): N 232,151; E 175,324.

U.S. Geological Survey Site ID: 365032116243501.

2. Drilling and casing information:

Well started: August 17, 1983.

Well completed: September 30, 1983.

Drilling method: Rotary, using rock bits and air-foam circulating medium; core obtained from bottom of the borehole.

Bit diameter below water level: $222 \mathrm{~mm}$.

Casing: Surface casing only, to a depth of $36.6 \mathrm{~m}$.

Total drilled depth: $399 \mathrm{~m}$.

3. Access to and description of interval for measuring water levels:

62-mm inside-diameter tubing that has a 3.7-m-long well screen on the bottom; tubing and attached screen extend from land surface to a depth of $397.2 \mathrm{~m}$; saturated interval of the borehole is within the Topopah Spring Tuff of the Paintbrush Group and the Calico Hills Formation.

4. Information for calculating water-level altitude:

Reference point: Top of metal tag on well casing, altitude 1,076.05 m (surveyed by U.S. Geological Survey, 1984).

Measuring point: Top of access tube, $0.311 \mathrm{~m}$.

Depth correction for borehole deviation from vertical: $0.085 \mathrm{~m}$, based on approximate depth to water of $346 \mathrm{~m}$ (1990 data).

Well UE-25 WT \#14 was measured periodically and hourly during 1994. Periodic measurements were made through June 22, 1994 using Chain \#3 with the following results:

\begin{tabular}{ccc}
\hline Date & $\begin{array}{c}\text { Measured water-level altitude } \\
\text { (meters, above sea level) }\end{array}$ & Method \\
\hline $02-03-94$ & 729.68 & Chain \#3 \\
$02-28-94$ & 729.61 & Chain \#3 \\
$03-15-94$ & 729.68 & Chain \#3 \\
$04-15-94$ & 729.60 & Chain \#3 \\
$05-26-94$ & 729.67 & Chain \#3 \\
$06-07-94$ & 729.64 & Chain \#3 \\
$06-22-94$ & 729.63 & Chain \#3 \\
\hline
\end{tabular}


The well was instrumented with a transducer on June 22,1994 , and hourly measurements collected for the remainder of the year. During the period of hourly measurements two calibrations of one transducer were performed. In addition, a calibration was completed on January 24, 1995. This calibration was used to calculate water-level altitudes at the end of 1994. Results of the calibrations and measured water-level altitudes obtained during the calibration are as follows:

\begin{tabular}{ccccc}
\hline $\begin{array}{c}\text { Transducer serial } \\
\text { number }\end{array}$ & Calibration date & $\begin{array}{c}\text { Slope } \\
\text { (meters/millivolt) }\end{array}$ & $\begin{array}{c}\text { Coetficient of } \\
\text { determination }\end{array}$ & $\begin{array}{c}\text { Water-level } \\
\text { allitude' } \\
\text { (meters) }\end{array}$ \\
\hline 592473 & $06-22-94$ & 0.088 & 1.00 & 729.63 \\
592473 & $09-20-94$ & .088 & 1.00 & 729.60 \\
592473 & $01-24-95$ & .089 & 1.00 & 729.64 \\
\hline
\end{tabular}

All other water-level measurements were made by tagging the water-surface with the transducer that was being calibrated.

All transducer data collected for UE-25 WT \#14 for 1994 were considered to be valid with no lost record from June 22, 1994, through the end of the year.

Water-level altitudes for well UE-25 WT \#14 ranged from 729.52 to $729.69 \mathrm{~m}$ above sea level in 1994 (fig. 12). Mean monthly water-level altitudes for June through December 1994 are listed in table 11. The mean annual water-level altitude for 1994 was $729.61 \mathrm{~m}$ above sea level. This mean altitude was $0.05 \mathrm{~m}$ lower than the mean altitude of $729.66 \mathrm{~m}$ for 1993 (Tucci, Goemaat, and Burkhardt, 1996). 


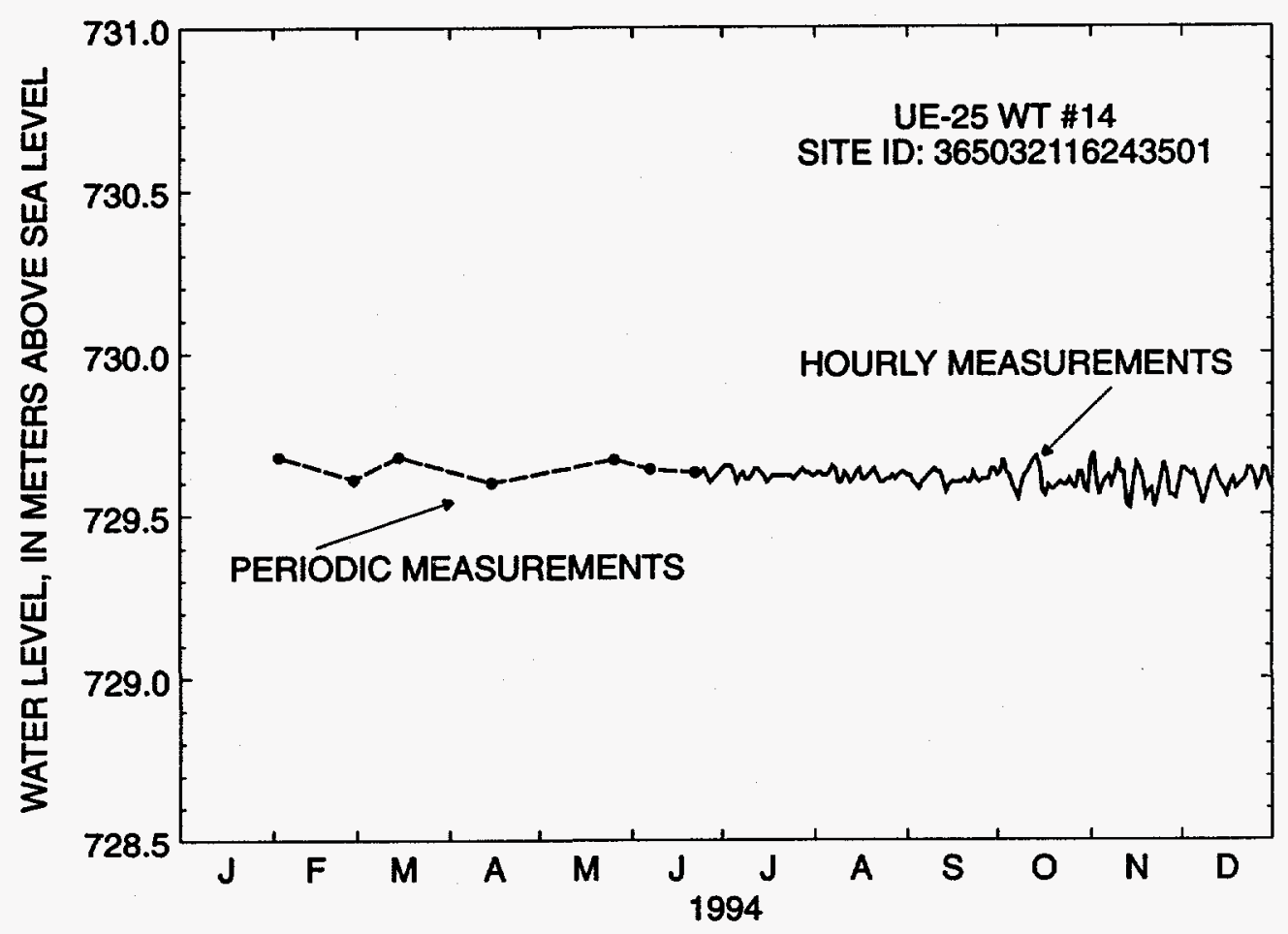

Figure 12. Water-level altitudes, 1994, for well UE-25 WT \#14.

Table 11. Mean monthly water-level altitudes, 1994, for well UE-25 WT \#14

[Monthly means were calculated regardless of the number of days of missing data. Daily means were not calculated if 6 or more consecutive hours of data were missing; ..., data not available; NA, not applicable, well not instrumented during this month]

\begin{tabular}{lcc}
\hline Month & $\begin{array}{c}\text { Water-level altitude } \\
\text { (meters, above } \\
\text { sea level) }\end{array}$ & $\begin{array}{c}\text { Number of missing } \\
\text { daily means }\end{array}$ \\
\hline January & -- & NA \\
February & - & NA \\
March & -- & NA \\
April & -- & NA \\
May & -- & NA \\
June & 729.62 & 22 \\
July & 729.62 & 0 \\
August & 729.62 & 0 \\
September & 729.61 & 0 \\
October & 729.61 & 0 \\
November & 729.60 & 0 \\
December & 729.60 & 0 \\
\hline
\end{tabular}




\section{Well UE-25 WT \#15}

Information about the history of well UE-25 WT \#15 and about previous data from the well was obtained from various sources. These sources are: Robison (1984, 1986); Robison and others (1988); Holmes \& Narver, Inc. (written commun., 1986); and Fenix \& Scisson, Inc. (1986a, 1987c).

Well specifications

1. Location and identification:

Latitude and longitude: $36^{\circ} 51^{\prime} 16^{\prime \prime} \mathrm{N}$.; $116^{\circ} 23^{\prime} 38^{\prime \prime} \mathrm{W}$.

Nevada State Central Zone Coordinates (m): N 233,512; E 176,725.

U.S. Geological Survey Site ID: 365116116233801.

2. Drilling and casing information:

Well started: November 12, 1983.

Well completed: November 22, 1983.

Drilling method: Rotary, using rock bits and air-foam circulating medium; core obtained from bottom of the borehole.

Bit diameter below water level: $222 \mathrm{~mm}$.

Casing: Surface casing only, to a depth of $38.7 \mathrm{~m}$.

Total drilled depth: $415 \mathrm{~m}$.

3. Access to and description of interval for measuring water levels:

62-mm inside-diameter tubing that has a 3.7-m-long well screen on the bottom; tubing and attached screen extend from land surface to a depth of $406.9 \mathrm{~m}$; saturated interval of the borehole is within the Topopah Spring Tuff of the Paintbrush Group.

4. Information for calculating water-level altitude:

Reference point: Top of metal tag on well casing, altitude $1,082.94 \mathrm{~m}$ (surveyed by U.S. Geological Survey, 1984).

Measuring point: Top of access tube, $0.314 \mathrm{~m}$.

Depth correction for borehole deviation from vertical: $0.189 \mathrm{~m}$, based on approximate depth to water of $354 \mathrm{~m}$ (1990 data).

Well UE-25 WT \#15 was measured periodically during 1994. All measurements were made with Chain \#3 with the following results: 


\begin{tabular}{ccc}
\hline Date & $\begin{array}{c}\text { Measured water-tevel alttude } \\
\text { (moters, above sea lovel) }\end{array}$ & Mothod \\
\hline $01-31-94$ & 729.12 & Chain \#3 \\
$02-28-94$ & 729.15 & Chain \#3 \\
$03-28-94$ & 729.17 & Chain \#3 \\
$04-29-94$ & 729.17 & Chain \#3 \\
$05-26-94$ & 729.21 & Chain \#3 \\
$06-07-94$ & 729.20 & Chain \#3 \\
$07-15-94$ & 729.17 & Chain \#3 \\
$08-15-94$ & 729.18 & Chain \#3 \\
$09-28-94$ & 729.17 & Chain \#3 \\
$10-13-94$ & 729.28 & Chain \#3 \\
$11-03-94$ & 729.21 & Chain \#3 \\
$12-13-94$ & 729.21 & Chain \#3 \\
\hline
\end{tabular}

Water-level altitudes for well UE-25 WT \#15 ranged from 729.12 to $729.28 \mathrm{~m}$ above sea level in 1994 (fig. 13). The mean annual water-level altitude for 1994 was $729.19 \mathrm{~m}$ above sea level. This mean altitude vwas $0.03 \mathrm{~m}$ lower than the mean altitude of $729.22 \mathrm{~m}$ for 1993 (Tucci, Goemaat, and Burkhardt, 1996).

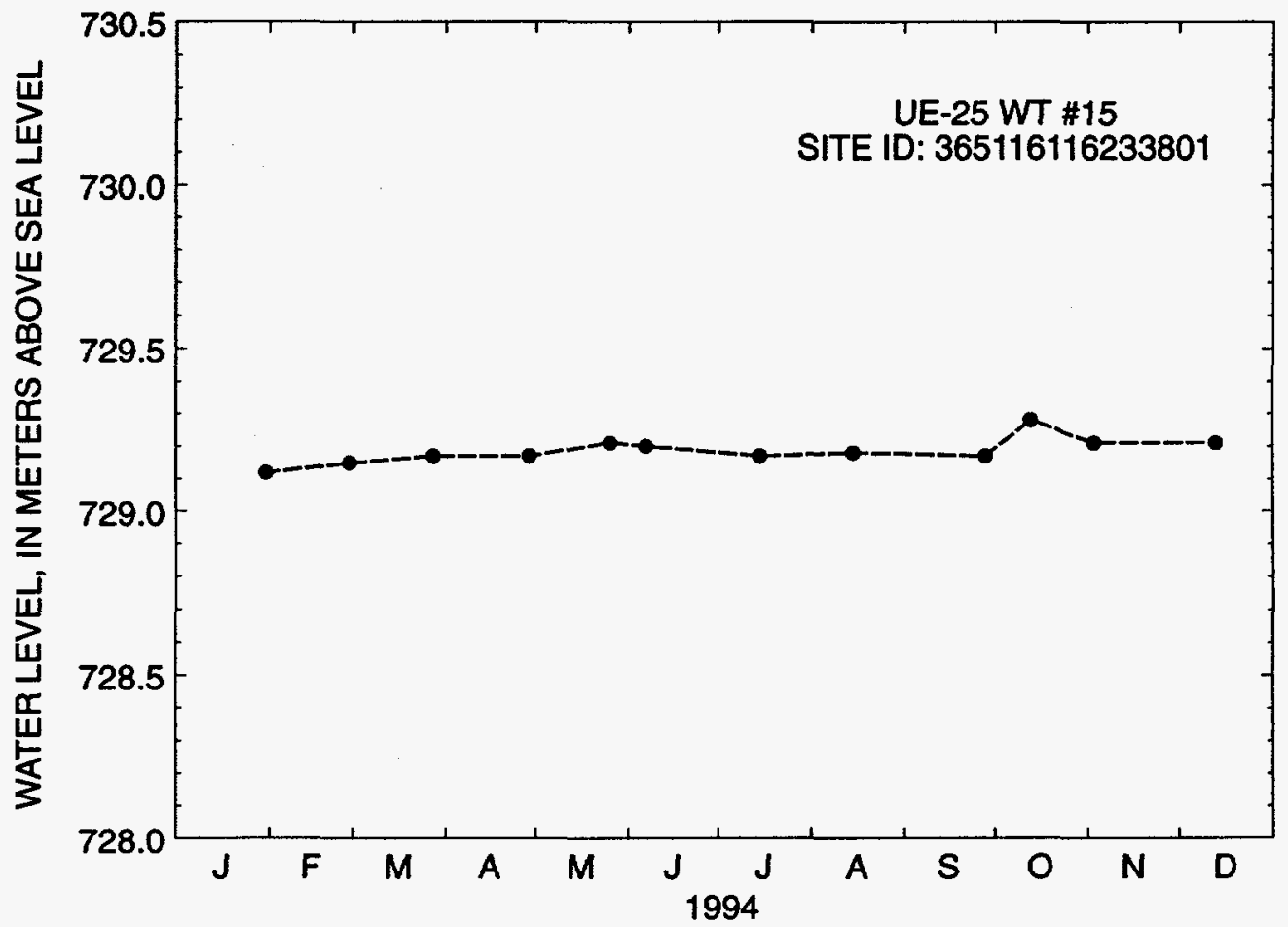

Figure 13. Water-level altitudes, 1994, for well UE-25 WT \#15. 


\section{Well UE-25 WT \#16}

Information about the history of well UE-25 WT \#16 and about previous data from the well was obtained from various sources. These sources are: Robison $(1984,1986)$; Robison and others (1988); and Fenix \& Scisson, Inc. (1986a, 1987c).

\section{Well specifications}

1. Location and identification:

Latitude and longitude: $36^{\circ} 52^{\prime} 39^{\prime \prime N}$.; $116^{\circ} 25^{\prime} 34^{\prime \prime} \mathrm{W}$.

Nevada State Central Zone Coordinates (m): N 236,043; E 173,856.

U.S. Geological Survey Site ID: 365239116253401.

2. Drilling and casing information:

Well started: November 2, 1983.

Well completed: November 10, 1983.

Drilling method: Rotary, using rock bits and air-foam circulating medium; core obtained from bottom of the core hole.

Bit diameter below water level: $222 \mathrm{~mm}$.

Casing: Surface casing only, to a depth of $31 \mathrm{~m}$.

Total drilled depth: $521 \mathrm{~m}$.

3. Access to and description of interval for measuring water levels:

62-mm inside-diameter tubing that has a 3.6-m-long well screen on bottom, extending from land surface to a depth of $514 \mathrm{~m}$; saturated interval of borehole is within the Calico Hills Formation.

4. Information for calculating water-level altitude:

Reference point: Top of metal tag on well casing; altitude $1,210.63 \mathrm{~m}$ (surveyed by U.S. Geological Survey, 1984).

Measuring point: Top of access tube, $0.314 \mathrm{~m}$.

Depth correction for borehole deviation from vertical: $0.064 \mathrm{~m}$, based on approximate depth to water of $473 \mathrm{~m}$ (1990 data).

Well UE-25 WT \#16 was measured periodically during 1994. All measurements were made with Chain \#3 with the following results: 


\begin{tabular}{ccc}
\hline Date & $\begin{array}{c}\text { Moasured water-lovel altitude } \\
\text { (moters, above sea lovel) }\end{array}$ & Mothod \\
\hline $01-31-94$ & 738.20 & Chain \#3 \\
$02-28-94$ & 738.25 & Chain \#3 \\
$03-28-94$ & 738.25 & Chain \#3 \\
$04-29-94$ & 738.29 & Chain \#3 \\
$05-12-94$ & 738.32 & Chain \#3 \\
$06-07-94$ & 738.37 & Chain \#3 \\
$07-15-94$ & 738.38 & Chain \#3 \\
$08-15-94$ & 738.38 & Chain \#3 \\
$09-28-94$ & 738.41 & Chain \#3 \\
$10-13-94$ & 738.45 & Chain \#3 \\
$11-03-94$ & 738.44 & Chain \#3 \\
$12-13-94$ & 738.40 & Chain \#3 \\
\hline
\end{tabular}

Water-level altitudes for well UE-25 WT \#16 ranged from 738.20 to $738.45 \mathrm{~m}$ above sea level in 1994 (fig. 14). The mean annual water-level altitude for 1994 was $738.35 \mathrm{~m}$ above sea level. This mean altitude was $0.08 \mathrm{~m}$ higher than the mean altitude of $738.27 \mathrm{~m}$ for 1993 (Tucci, Goemaat, and Burkhardt, 1996).

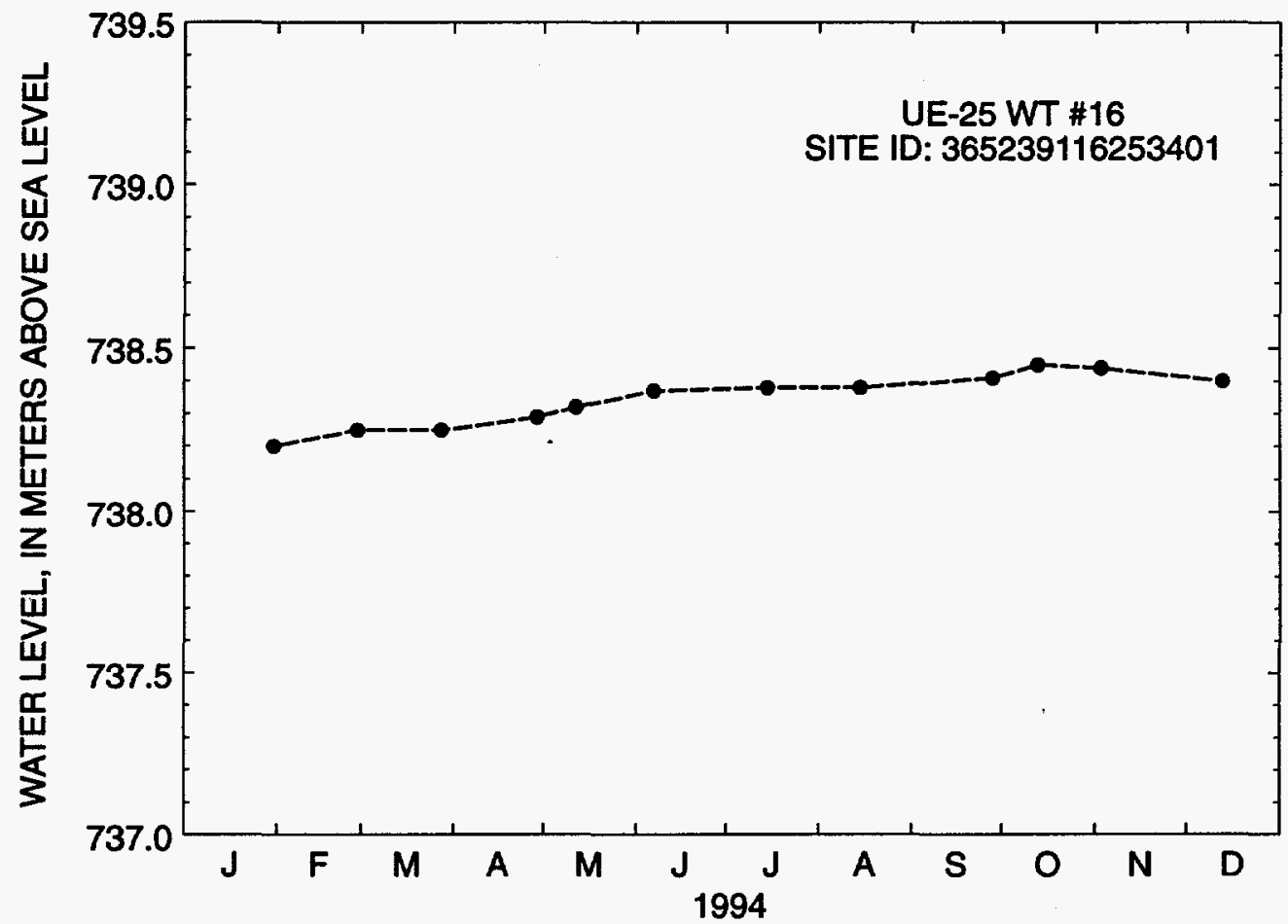

Figure 14. Water-level altitudes, 1994, for well UE-25 WT \#16. 


\section{Well UE-25 WT \#17}

Information about the history of well UE-25 WT \#17 and about previous data from the well was obtained from various sources. These sources are: Robison $(1984,1986)$; Robison and others (1988); Holmes \& Narver, Inc. (written commun., 1986); and Fenix \& Scisson, Inc. (1986a, 1987c).

Well specifications

1. Location and identification:

Latitude and longitude: $36^{\circ} 48^{\prime} 22^{\prime \prime} \mathrm{N}$.; $116^{\circ} 26^{\prime} 26^{\prime \prime} \mathrm{W}$.

Nevada State Central Zone Coordinates (m): N 228,118; E 172,581.

U.S. Geological Survey Site ID: 364822116262601.

2. Drilling and casing information:

Well started: October 20, 1983.

Well completed: October 30, 1983.

Drilling method: Rotary, using rock bits and air-foam circulating medium; attempt to obtain bottom-hole core unsuccessful, core not obtained from bottom of borehole.

Bit diameter below water level: $222 \mathrm{~mm}$.

Casing: Surface casing only, to a depth of $16.8 \mathrm{~m}$.

Total drilled depth: $443 \mathrm{~m}$.

3. Access to and description of interval for measuring water levels:

62-mm inside-diameter tubing that has a 3.7-m-long well screen on the bottom; tubing and attached screen extend from land surface to a depth of $419.4 \mathrm{~m}$; saturated interval of borehole is within the Prow Pass Tuff of the Crater Flat Group.

4. Information for calculating water-level altitude:

Reference point: Top of metal tag on well casing, altitude $1,124.06 \mathrm{~m}$ (surveyed by U.S. Geological Survey, 1984).

Measuring point: Top of access tube, $0.158 \mathrm{~m}$.

Depth correction for borehole deviation from vertical: $0.482 \mathrm{~m}$, based on approximate depth to water of $394 \mathrm{~m}$ (1990 data).

Well UE-25 WT \#17 was measured periodically during 1994. Measurements were made with Chain \#3 and the multiconductor cable unit with the following results: 


\begin{tabular}{ccc}
\hline Date & $\begin{array}{c}\text { Mossured water-tevel altitude } \\
\text { (meters, above sou level) }\end{array}$ & Method \\
\hline $01-06-94$ & 729.47 & Multiconductor cable unit \\
$02-02-94$ & 729.71 & Chain \#3 \\
$03-01-94$ & 729.56 & Chain \#3 \\
$03-16-94$ & 729.73 & Chain \#3 \\
$05-02-94$ & 729.68 & Chain \#3 \\
$05-26-94$ & 729.68 & Chain \#3 \\
$06-30-94$ & 729.66 & Chain \#3 \\
$07-19-94$ & 729.65 & Chain \#3 \\
$08-31-94$ & 729.67 & Chain \#3 \\
$09-30-94$ & 729.69 & Chain \#3 \\
$10-20-94$ & 729.64 & Chain \#3 \\
$12-02-94$ & 729.52 & Multiconductor cable unit \\
\hline
\end{tabular}

Water-level altitudes for well UE-25 WT \#17 ranged from 729.47 to $729.73 \mathrm{~m}$ above sea level in 1994 (fig. 15). The mean annual water-level altitude for 1994 was $729.64 \mathrm{~m}$ above sea level. This mean altitude was $0.05 \mathrm{~m}$ lower than the mean altitude of $729.69 \mathrm{~m}$ for 1993 (Tucci, Goemaat, and Burkhardt, 1996).

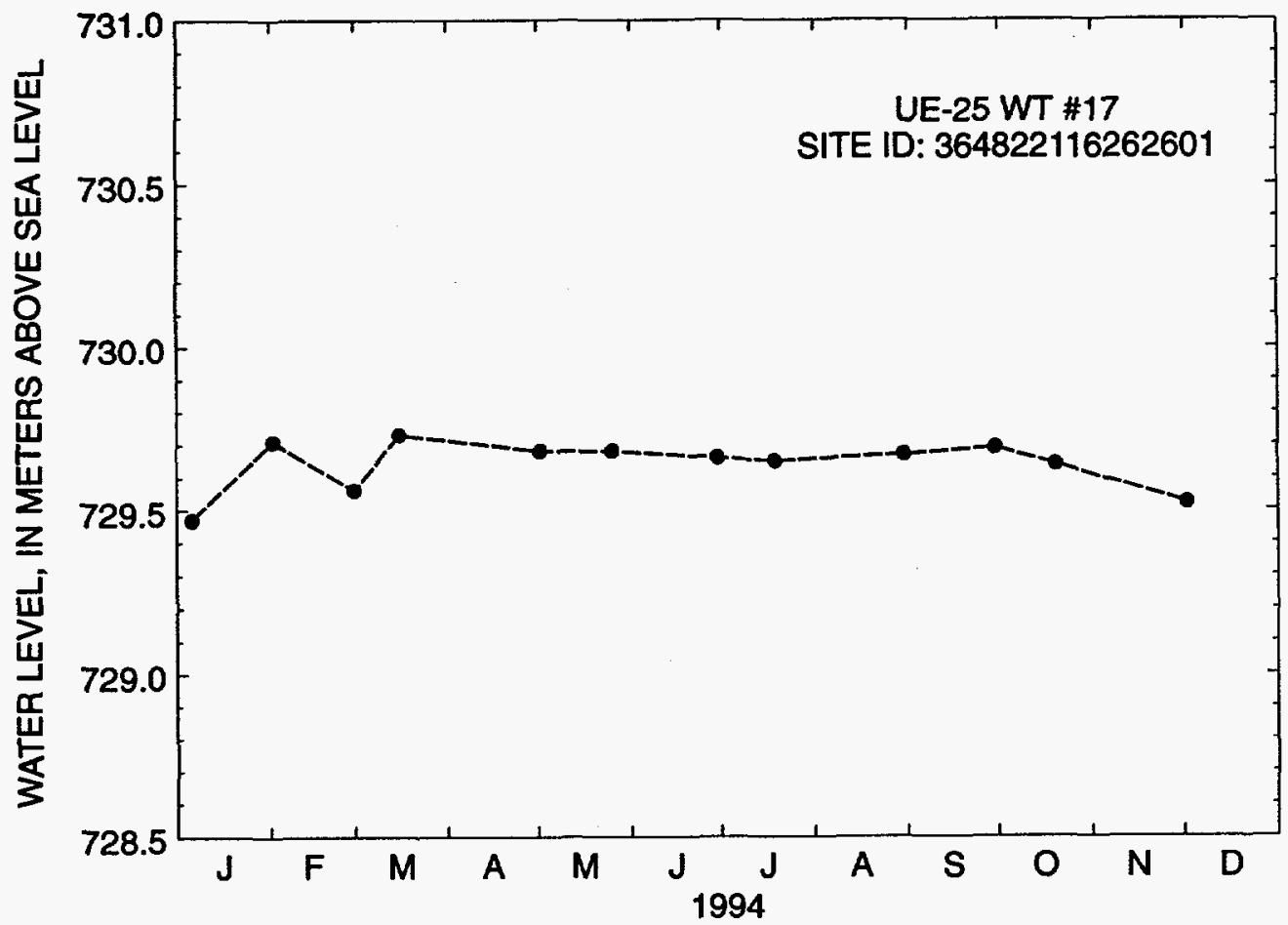

Figure 15. Water-level altitudes, 1994, for well UE-25 WT \#17. 


\section{Well UE-25 WT \#18}

Information about the history of well UE-25 WT \#18 and about previous data from the well was obtained from various sources. These sources are: Fenix \& Scisson, Inc. (1986a); Holmes \& Narver, Inc. (written commun., 1986); and Muller and Kibler (1985).

Well specifications

1. Location and identification:

Latitude and longitude: $36^{\circ} 52^{\prime} 07^{\prime \prime} \mathrm{N} ; 116^{\circ} 26^{\prime} 42^{\prime \prime} \mathrm{W}$.

Nevada State Central Zone Coordinates (m): N 235,052; E 172,168.

U.S. Geological Survey Site ID: 365207116264201.

2. Drilling and casing information:

Well started: May 9, 1984.

Well completed: May 23, 1984.

Drilling method: Rotary using rock bits and air-foam circulating medium; core obtained from bottom of the borehole.

Bit diameter below water level: $222 \mathrm{~mm}$.

Casing: Surface casing only, to a depth of $27 \mathrm{~m}$.

Total depth drilled: $623 \mathrm{~m}$.

3. Access to and description of interval for measuring water levels:

62-mm inside-diameter tubing that has a $3.7-\mathrm{m}$-long well screen on the bottom; tubing and attached screen originally extended from land surface to a depth of $597 \mathrm{~m}$, but tubing was extended to a depth of 609 m, December 1990; saturated interval is within the Calico Hills Formation.

4. Information for calculating water-level altitude:

Reference point: Top of metal tag on well casing, altitude $1336.32 \mathrm{~m}$ (surveyed by U.S. Geological Survey, 1984).

Measuring point: Top of access tube, $0.210 \mathrm{~m}$.

Depth correction for borehole deviation from vertical: $0.155 \mathrm{~m}$, based on approximate depth to water of $607 \mathrm{~m}$ (1990 data).

Well UE-25 WT \#18 was measured periodically during 1994. All measurements were made with Chain \#3 with the following results: 


\begin{tabular}{ccc}
\hline Date & $\begin{array}{c}\text { Measured water-level altitude } \\
\text { (moters, above sea lovel) }\end{array}$ & Mothod \\
\hline $02-03-94$ & 730.75 & Chain \#3 \\
$03-01-94$ & 730.71 & Chain \#3 \\
$03-16-94$ & 730.76 & Chain \#3 \\
$04-21-94$ & 730.76 & Chain \#3 \\
$05-26-94$ & 730.75 & Chain \#3 \\
$06-30-94$ & 730.73 & Chain \#3 \\
$07-19-94$ & 730.69 & Chain \#3 \\
$08-31-94$ & 730.77 & Chain \#3 \\
$09-23-94$ & 730.74 & Chain \#3 \\
$10-24-94$ & 730.52 & Chain \#3 \\
$11-10-94$ & 730.66 & Chain \#3 \\
$12-14-94$ & 730.57 & Chain \#3 \\
\hline
\end{tabular}

Water-level altitudes for well UE-25 WT \#18 ranged from 730.52 to $730.77 \mathrm{~m}$ above sea level in 1994 (fig. 16). The mean annual water-level altitude for 1994 was $730.70 \mathrm{~m}$ above sea level. This mean altitude was $0.07 \mathrm{~m}$ lower than the mean altitude of $730.77 \mathrm{~m}$ for 1993 (Tucci, Goemaat, and Burkhardt, 1996).

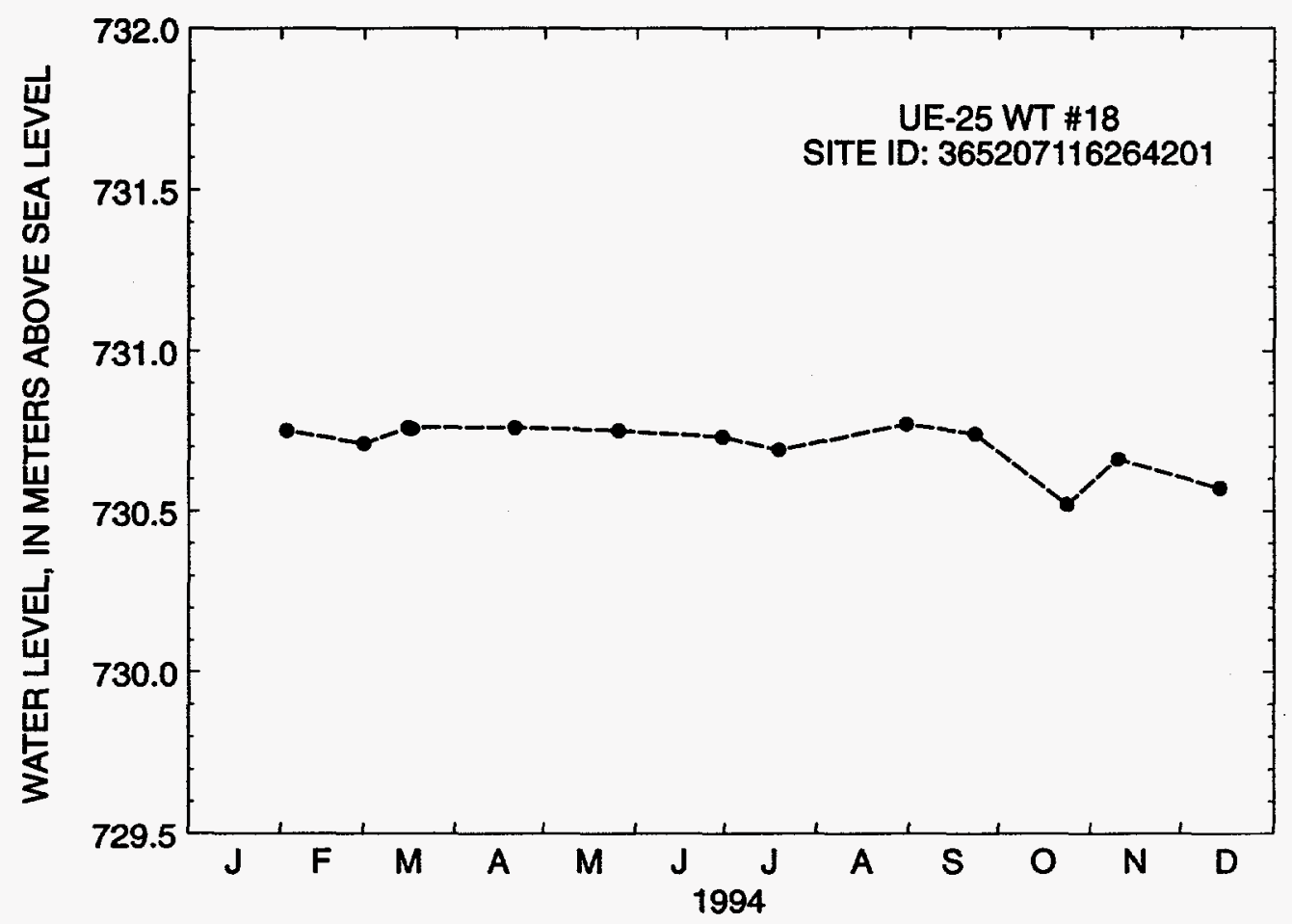

Figure 16. Water-level altitudes, 1994, for well UE-25 WT \#18. 


\section{Well UE-25b \#1}

Information about the history of well UE-25b \#1 and about previous data from the well was obtained from various sources. These sources are: Lobmeyer and others (1983); Lahoud and others (1984); Robison (1984, 1986); Robison and others (1988); and Fenix \& Scisson, Inc. (1986b, 1987c).

\section{Well specifications}

1. Location and identification:

Latitude and longitude: $36^{\circ} 51^{\prime} 08^{\prime \prime} \mathrm{N}$.; $116^{\circ} 26^{\prime} 23^{\prime \prime} \mathrm{W}$.

Nevada State Central Zone Coordinates (m): N 233,246; E 172,644.

U.S. Geological Survey Site ID: 365108116262301.

2. Drilling and casing information:

Well started: April 3, 1981.

Well completed: September 22, 1981.

Drilling method: Rotary, using rock bits and air-foam circulating medium; cores obtained from selected intervals.

Bit diameter below water level: $311 \mathrm{~mm}$ to $520 \mathrm{~m} ; 222 \mathrm{~mm}$ to $650 \mathrm{~m} ; 216 \mathrm{~mm}$ from 650 to $1,220 \mathrm{~m}$.

Casing extending below water level: $226-\mathrm{mm}$ inside diameter to $518 \mathrm{~m}$; casing string is tack cemented in and perforated below the water level.

Total drilled depth: $1,220 \mathrm{~m}$.

3. Access to and description of interval for measuring water levels:

\section{Upper interval:}

48-mm inside diameter tubing, open ended, to depth of about $488 \mathrm{~m}$; upper interval of borehole, from near water table to top of inflatable packer, is within the Calico Hills Formation, and Prow Pass, Bullfrog, and upper Tram Tuffs of the Crater Flat Group;

\section{Lower interval:}

62-mm inside diameter tubing that has an inflatable packer on bottom end, to depth of $1,199 \mathrm{~m}$; lower interval of borehole, from below packer to bottom of well, is within the lower Tram Tuff of the Crater Flat Group and Lithic Ridge Tuff.

4. Information for calculating water-level altitude:

Reference point: Top of metal tag on well casing; altitude 1,200.73 m (surveyed by U.S. Geological Survey, 1984).

Measuring point: Top of access tubes, $0.302 \mathrm{~m}$, upper interval; $0.134 \mathrm{~m}$, lower interval.

Depth correction for borehole deviation from vertical: $0.244 \mathrm{~m}$, based on approximate depth to water of $470 \mathrm{~m}$ (1990 data). 
Well UE-25b \#1, upper interval was measured periodically during 1994. All measurements were made with Chain \#3 with the following results:

\begin{tabular}{ccc}
\hline Date & $\begin{array}{c}\text { Measured water-level altitude } \\
\text { (meters, above sea level) }\end{array}$ & Mothod \\
\hline $01-31-94$ & 730.53 & Chain \#3 \\
$02-28-94$ & 730.54 & Chain \#3 \\
$03-15-94$ & 730.59 & Chain \#3 \\
$04-21-94$ & 730.63 & Chain \#3 \\
$05-12-94$ & 730.61 & Chain \#3 \\
$06-24-94$ & 730.59 & Chain \#3 \\
$07-19-94$ & 730.58 & Chain \#3 \\
$08-18-94$ & 730.59 & Chain \#3 \\
$09-27-94$ & 730.60 & Chain \#3 \\
$10-20-94$ & 730.55 & Chain \#3 \\
$11-09-94$ & 730.66 & Chain \#3 \\
$12-27-94$ & 730.67 & Chain \#3 \\
\hline
\end{tabular}

Water-level altitudes for well UE-25b \#1, upper interval ranged from 730.53 to $730.67 \mathrm{~m}$ above sea level in 1994 (fig. 17). The mean annual water-level altitude for 1994 was $730.60 \mathrm{~m}$ above sea level. This mean altitude was $0.01 \mathrm{~m}$ lower than the mean altitude of $730.61 \mathrm{~m}$ for 1993 (Tucci, Goemaat, and Burkhardt, 1996).

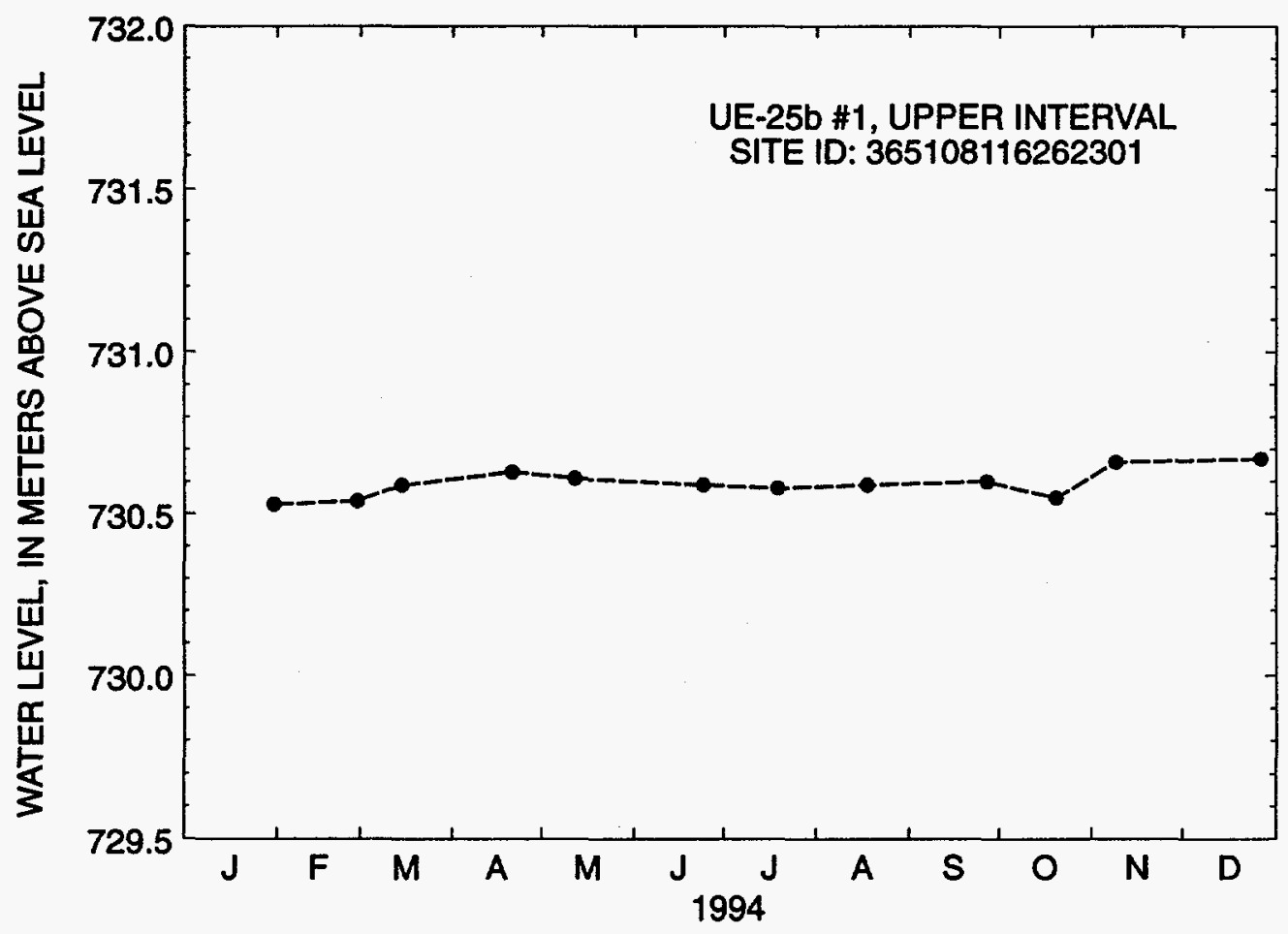

Figure 17. Water-level altitudes, 1994, for well UE-25b \#1, upper interval. 


\section{United States Department of the Interior}

U. S. GEOLOGICAL SURVEY

Box 25046 M.S. $\quad 421$

Denver Federal Center

Denver, Colorado 80225

IN REPLY REFER TO

WBS: 1.2.3.3.1.3.1

\section{MEMORANDUM}

Date: January 9,1997

To: Distribution 0

From: Becci Claytof, Reports Processing Unit, ESIP, YMPB, Denver, CO, MS 421

Re: $\quad$ PUBLICATIONS -- ERRATA sheet for Open-File Report 95-757, "Water levels in the Yucca Mountain area, Nevada, 1994", by R.P. Graves, P. Tucci, and R.L. Goemaat

Attached is a replacement page containing a correction for the above listed report.

An error was made during printing which occurred to the line " $\mathrm{S}_{\mathrm{c}}=0.44$ meters $/$ millivolt", on page 14 . The correct line should read " $S_{c}=\mathbf{0 . 0 4 4}$ meters/millivolt".

Apologies are made for any inconvenience this may have caused. 
Well UE-25b \#1, lower interval was measured periodically during 1994. All measurements were made with the multiconductor cable unit with the following results:

\begin{tabular}{ccl}
\hline Date & $\begin{array}{c}\text { Moasured water-level altitude } \\
\text { (meters, above sea level) }\end{array}$ & \multicolumn{1}{c}{ Method } \\
\hline $01-19-94$ & 730.09 & Multiconductor cable unit \\
$03-17-94$ & 730.09 & Multiconductor cable unit \\
$04-25-94$ & 730.07 & Multiconductor cable unit \\
$05-31-94$ & 730.10 & Multiconductor cable unit \\
$06-23-94$ & 730.11 & Multiconductor cable unit \\
$07-21-94$ & 730.09 & Multiconductor cable unit \\
$08-12-94$ & 730.00 & Multiconductor cable unit \\
$09-27-94$ & 730.04 & Multiconductor cable unit \\
$10-19-94$ & 730.00 & Multiconductor cable unit \\
$11-30-94$ & 729.96 & Multiconductor cable unit \\
\hline
\end{tabular}

Water-level altitudes for well UE-25b \#1, lower interval ranged from 729.96 to $730.11 \mathrm{~m}$ above sea level in 1994 (fig. 18). The mean annual water-level altitude for 1994 was $730.06 \mathrm{~m}$ above sea level. The only data available for 1993 is a single water-level measurement of $729.92 \mathrm{~m}$ above sea level, which was made on February 2, 1993. Subsequently, a comparison of annual water-level altitudes between 1993 and 1994 was not made.

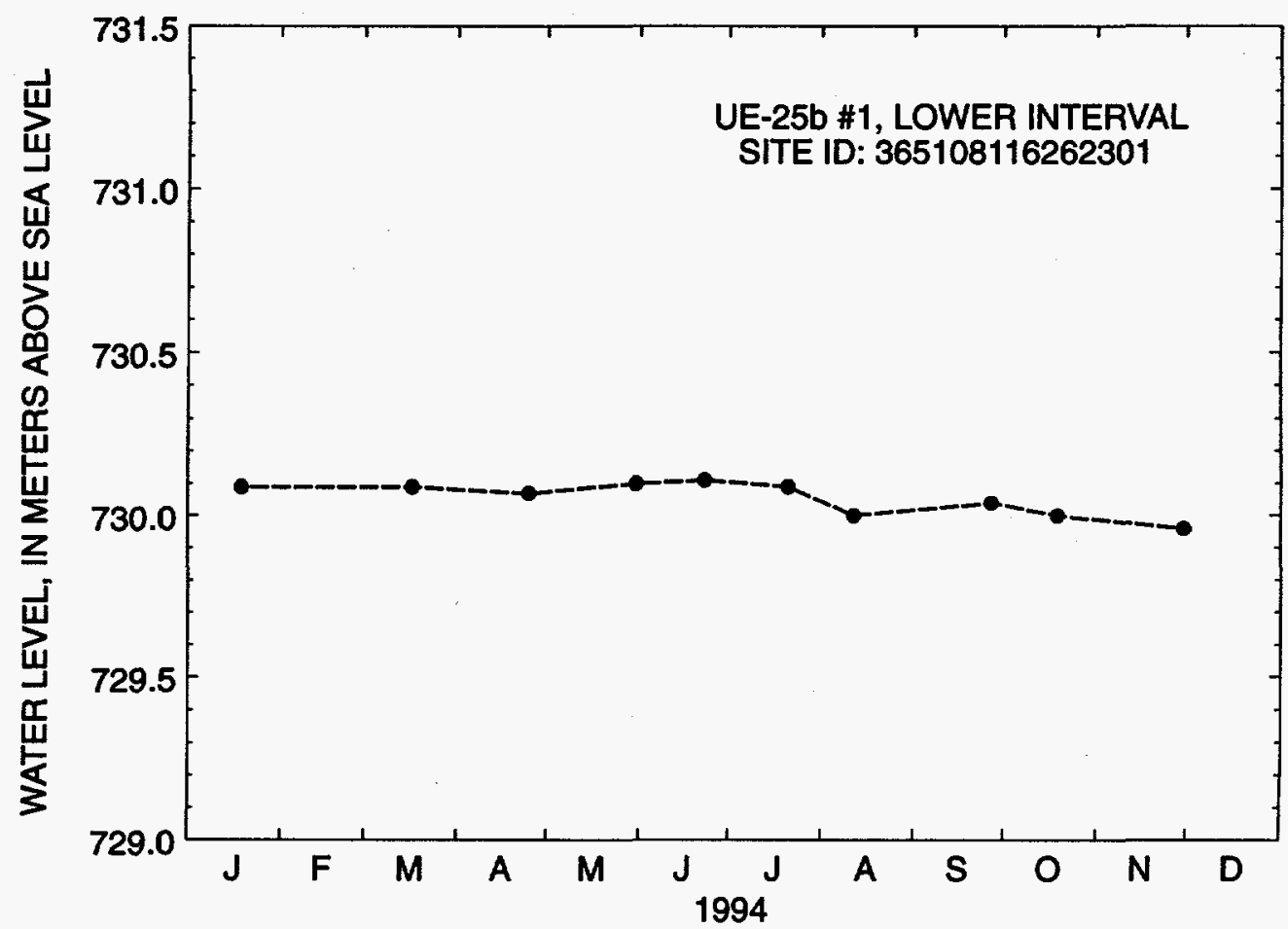

Figure 18. Water-level altitudes, 1994, for well UE-25b \#1, lower interval. 


\section{Well UE-25p \#1}

Information about the history of well UE-25p \#1 and about previous data from the well was obtained from various sources. These sources are: Craig and Johnson (1984); Craig and Robison (1984); Robison (1984, 1986); Robison and others (1988); and Fenix \& Scisson, Inc. (1986c, 1987c).

\section{Well specifications}

1. Location and identification:

Latitude and longitude: $36^{\circ} 49^{\prime} 38^{\prime \prime} \mathrm{N}$.; $116^{\circ} 25^{\prime} 21^{\prime \prime} \mathrm{W}$.

Nevada State Central Zone Coordinates (m): N 230,481; E 174,188.

U.S. Geological Survey Site ID: 364938116252102.

2. Drilling and casing information:

Well started: November 13, 1982.

Well completed: May 24, 1983.

Drilling method: Rotary, using rock bits and air-foam circulating medium; cores obtained from selected intervals.

Bit diameter below water level: $375 \mathrm{~mm}$ to $487 \mathrm{~m} ; 251 \mathrm{~mm}$ from 487 to $1,304 \mathrm{~m}$;

$17 \mathrm{~mm}$ from 1,304 to $1,317 \mathrm{~m} ; 171 \mathrm{~mm}$ from 1,317 to $1,798 \mathrm{~m} ; 156 \mathrm{~mm}$ from 1,798

to $1,805 \mathrm{~m}$.

Casing extending below water level: $255-\mathrm{mm}$ inside diameter from land surface to $477 \mathrm{~m}$; $177-\mathrm{mm}$ inside diameter from 453 to $1,297 \mathrm{~m}$; casing string is cemented in, has no perforations.

Total drilled depth: $1,805 \mathrm{~m}$.

3. Access to and description of interval for measuring water levels:

38-mm inside-diameter tubing, open end, to depth of $418 \mathrm{~m}$; well construction is such that water level of the tuffs of Tertiary age is not monitored. Only the water level in the underlying carbonate rocks of Paleozoic age is measured (Tertiary-Paleozoic contact is at $1,244 \mathrm{~m}$ ).

Note: A 38-mm inside-diameter tubing, closed end, and filled with water, to a depth of $413 \mathrm{~m}$ below land surface is also installed in the well to allow access for temperature logging.

4. Information for calculating water-level altitude:

Reference point: Top of metal tag on well casing; altitude 1,114.21 m (surveyed by U.S. Geological Survey, 1984).

Measuring point: Top of access tube, $0.158 \mathrm{~m}$.

Depth correction for borehole deviation from vertical: $0.021 \mathrm{~m}$, based on approximate depth to water of $362 \mathrm{~m}$ (1990 data).

Well UE-25p \#1 was measured hourly during 1994. Four calibrations of two transducers were performed during 1994. In addition, calibrations on December 2, 1993, and February 16, 1995, were used to calculate water levels for 1994. Results of the calibrations and measured water-level altitudes obtained during the calibrations are as follows: 


\begin{tabular}{ccccc}
\hline $\begin{array}{c}\text { Transeducer serial } \\
\text { number }\end{array}$ & Calibration date & $\begin{array}{c}\text { Slope } \\
\text { (motere/millivoit) }\end{array}$ & $\begin{array}{c}\text { Coofficiont of } \\
\text { determination }\end{array}$ & $\begin{array}{c}\text { Water-fevel } \\
\text { aftitude } \\
\text { (moters) }\end{array}$ \\
\hline 443988 & $12-02-93$ & 0.044 & 1.00 & 752.49 \\
443988 & $03-31-94$ & .044 & 1.00 & 752.49 \\
592477 & $03-31-94$ & .089 & 1.00 & 752.49 \\
592477 & $07-28-94$ & .089 & 1.00 & 752.60 \\
592477 & $11-23-94$ & .089 & 1.00 & 752.51 \\
592477 & $02-16-95$ & .088 & 1.00 & 752.50 \\
\hline
\end{tabular}

${ }^{1}$ Well UE-25p \#1: The water-level measurements made on March 31, 1994, and February 16, 1995, were made with Chain \#3. All other water-level measurements were made by tagging the water-surface with the transducer that was being calibrated.

No data are available from April 27 to May 2, 1994, and only partial data were collected on March 31, April 26, and May 3, 1994, due to lost power to the transducer. All other transducer data collected for 1994 were considered to be valid.

Water-level altitudes for well UE-25p \#1 ranged from 752.37 to $752.67 \mathrm{~m}$ above sea level in 1994 (fig. 19). Mean monthly water-level altitudes are listed in table 12. The mean annual water-level altitude for 1994, was $752.55 \mathrm{~m}$ above sea level. This mean altitude was $0.06 \mathrm{~m}$ higher than the mean altitude of $752.49 \mathrm{~m}$ for 1993 (Tucci, Goemaat, and Burkhardt, 1996). 


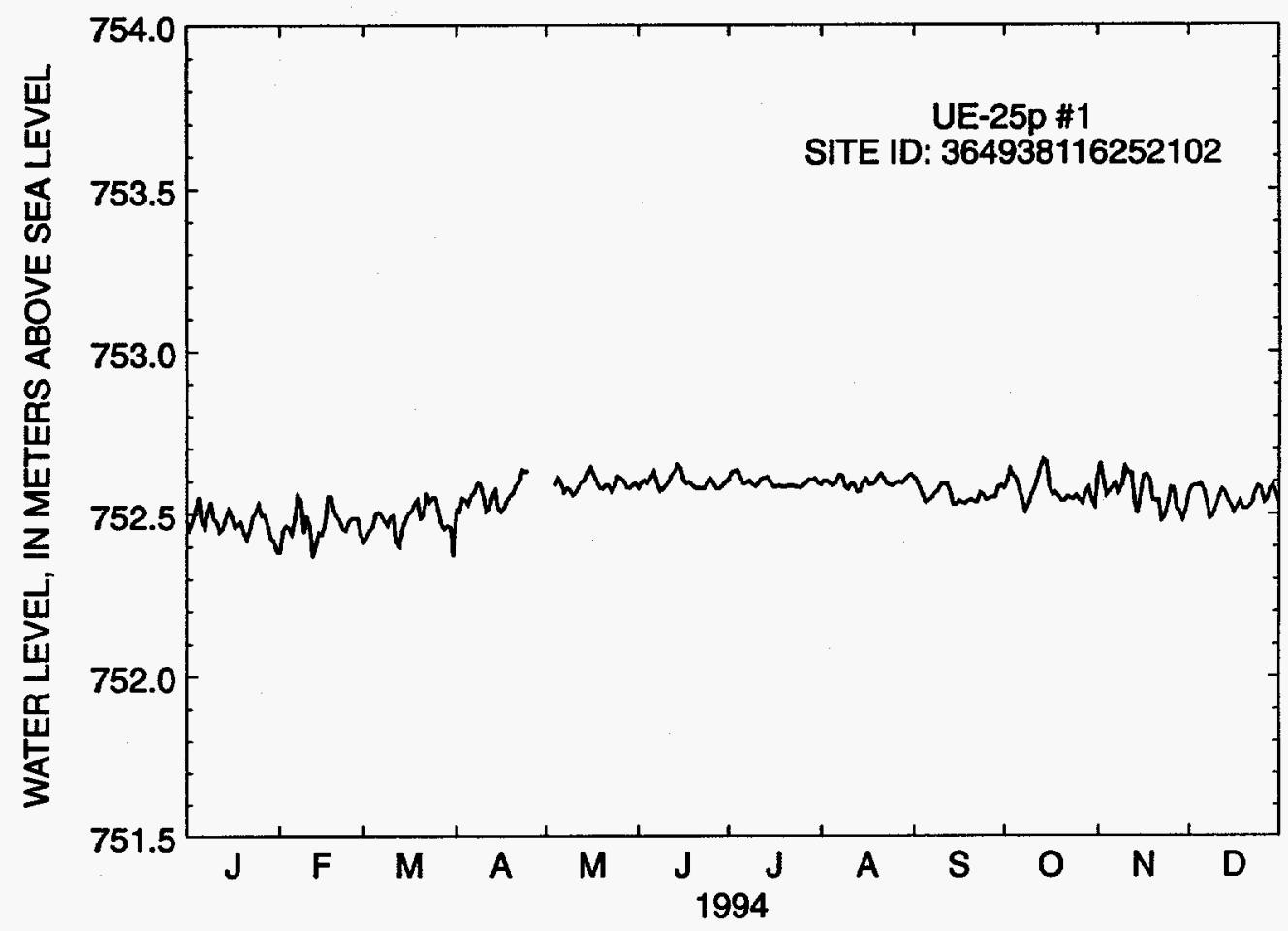

Figure 19. Water-level altitudes, 1994, for well UE-25p \#1.

Table 12. Mean monthly water-level altitudes, 1994 , for well UE-25p \# 1

[Monthly means were calculated regardless of the number of days of missing data. Daily means were not calculated if 6 or more consecutive hours of data were missing]

\begin{tabular}{lcc}
\hline Month & $\begin{array}{c}\text { Water-level altitude } \\
\text { (meters, above } \\
\text { sea level) }\end{array}$ & $\begin{array}{c}\text { Number of missing } \\
\text { dally means }\end{array}$ \\
\hline January & 752.48 & 0 \\
February & 752.47 & 0 \\
March & 752.48 & 0 \\
April & 752.56 & 5 \\
May & 752.59 & 3 \\
June & 752.60 & 0 \\
July & 752.60 & 0 \\
August & 752.60 & 0 \\
September & 752.56 & 0 \\
October & 752.57 & 0 \\
November & 752.57 & 0 \\
December & 752.55 & 0 \\
\hline
\end{tabular}




\section{Well USW G-2}

Information about the history of well USW G-2 and about previous data from the well was obtained from various sources. These sources are: Maldonado and Koether (1983); Robison $(1984,1986)$; Robison and others (1988); Holmes \& Narver, Inc. (written commun., 1986); Fenix \& Scisson, Inc. (1987b, 1987c); and Nelson and Schimschal (1993).

\section{Well specifications}

1. Location and identification:

Latitude and longitude: $36^{\circ} 53^{\prime} 22^{\prime \prime} \mathrm{N}$.; $116^{\circ} 27^{\prime} 35^{\prime \prime} \mathrm{W}$.

Nevada State Central Zone Coordinates (m): N 778,825; E 560,503.

U.S. Geological Survey Site ID: 365322116273501.

2. Drilling and casing information:

Well started: March 25, 1981.

Well completed: October 24, 1981.

Drilling method: Rotary, using rock bits, with polymer mud to $88 \mathrm{~m}$; cored from $88 \mathrm{~m}$ to total depth.

Bit diameter below water level: $222 \mathrm{~mm}$ to $814 \mathrm{~m}$; $159 \mathrm{~mm}$ from $814 \mathrm{~m}$ to $947 \mathrm{~m}$;

$156 \mathrm{~mm}$ from 947 to $1,439 \mathrm{~m} ; 76 \mathrm{~mm}$ from $1,439 \mathrm{~m}$ to total depth.

Casing extending below water level: None (surface casing, $320 \mathrm{~mm}$ inside diameter,

0-85 $\mathrm{m}$ and $276 \mathrm{~mm}$ inside diameter, 0-242 $\mathrm{m}$ ).

Total drilled depth: $1,831 \mathrm{~m}$.

3. Access to and description of interval for measuring water levels:

Saturated interval of borehole is within the Topopah Springs Tuff of the Paintbrush Group, the Calico Hills Formation, Prow Pass, Bullfrog, and Tram Tuffs of the Crater Flat Group, Lithic Ridge Tuff, and older flows and tuffs. Bridge plug at a depth of $806 \mathrm{~m}$.

4. Information for calculating water-level altitude:

Reference point: Top of metal tag on well casing, altitude $1,553.86 \mathrm{~m}$ (surveyed by U.S. Geological Survey, 1984).

Measuring point: Top of casing, $0.332 \mathrm{~m}$ after 2/3/93, $0.033 \mathrm{~m}$ prior to $2 / 3 / 93$.

Depth correction for borehole deviation from vertical: $0.158 \mathrm{~m}$, based on approximate depth to water of $524 \mathrm{~m}$ (1984 data).

Well USW G-2 was measured periodically and hourly during 1994. Periodic measurements were made during February prior to the well being instrumented with a transducer on February 18, 1994. The transducer was removed from the well on November 14,1994, so hydraulic tests could be completed on the well. Periodic measurements were made for well USW G-2 during November and December. Chain \#3 was used for all of the periodic measurements for this well during 1994. The results of the periodic measurements on USW G-2 are as follows: 


\begin{tabular}{ccc}
\hline Date & $\begin{array}{c}\text { Measured watertovel altitude } \\
\text { (moters, above sea lovel) }\end{array}$ & Mothod \\
\hline $02-03-94$ & $1,020.18$ & Chain \#3 \\
$02-18-94$ & $1,020.30$ & Chain \#3 \\
$11-14-94$ & $1,019.98$ & Chain \#3 \\
$12-14-94$ & $1,020.04$ & Chain \#3 \\
\hline
\end{tabular}

During the period of hourly measurements three calibrations of one transducer were performed. Results of the calibration and measured water-level altitudes obtained during the calibration are as follows:

\begin{tabular}{lcccc}
$\begin{array}{c}\text { Transducer } \\
\text { serial number }\end{array}$ & Callbration date & $\begin{array}{c}\text { Slope } \\
\text { (motere/millivolt) }\end{array}$ & $\begin{array}{c}\text { Coefficient of } \\
\text { determination }\end{array}$ & $\begin{array}{c}\text { Water-level } \\
\text { altitude' } \\
\text { (motera) }\end{array}$ \\
\hline 1858DE & $02-18-94$ & 0.092 & 0.99 & $1,020.30$ \\
1858DE & $07-14-94$ & .091 & 0.99 & $1,020.12$ \\
1858DE & $11-14-94$ & .090 & 1.00 & $1,019.98$ \\
\hline \\
'Well USW G-2: The water-level measurements made on February 18 and November 14, 1994, \\
were made with Chain \#3. The measurement made on July 14, 1994, was made by tagging the water- \\
surface with the transducer that was being calibrated.
\end{tabular}

Because of a loose cable connection, the collection of continuous hourly data did not begin until February 22, 1994. Also, spikes, due to electronic problems on March 21, 22, and 26, 1994, were removed from the data. All other transducer data collected for 1994 were considered to be valid.

Water-level altitudes for well USW G-2 ranged from $1,019.98$ to $1,020.30 \mathrm{~m}$ above sea level in 1994 (fig. 20). Mean monthly water-level altitudes for February through November 1994, are listed in table 13. The mean annual water-level altitude for 1994 was $1,020.10 \mathrm{~m}$ above sea level. This mean altitude was $0.18 \mathrm{~m}$ lower than the mean altitude of $1,020.28 \mathrm{~m}$ for 1993 (Tucci, Goemaat, and Burkhardt, 1996). 


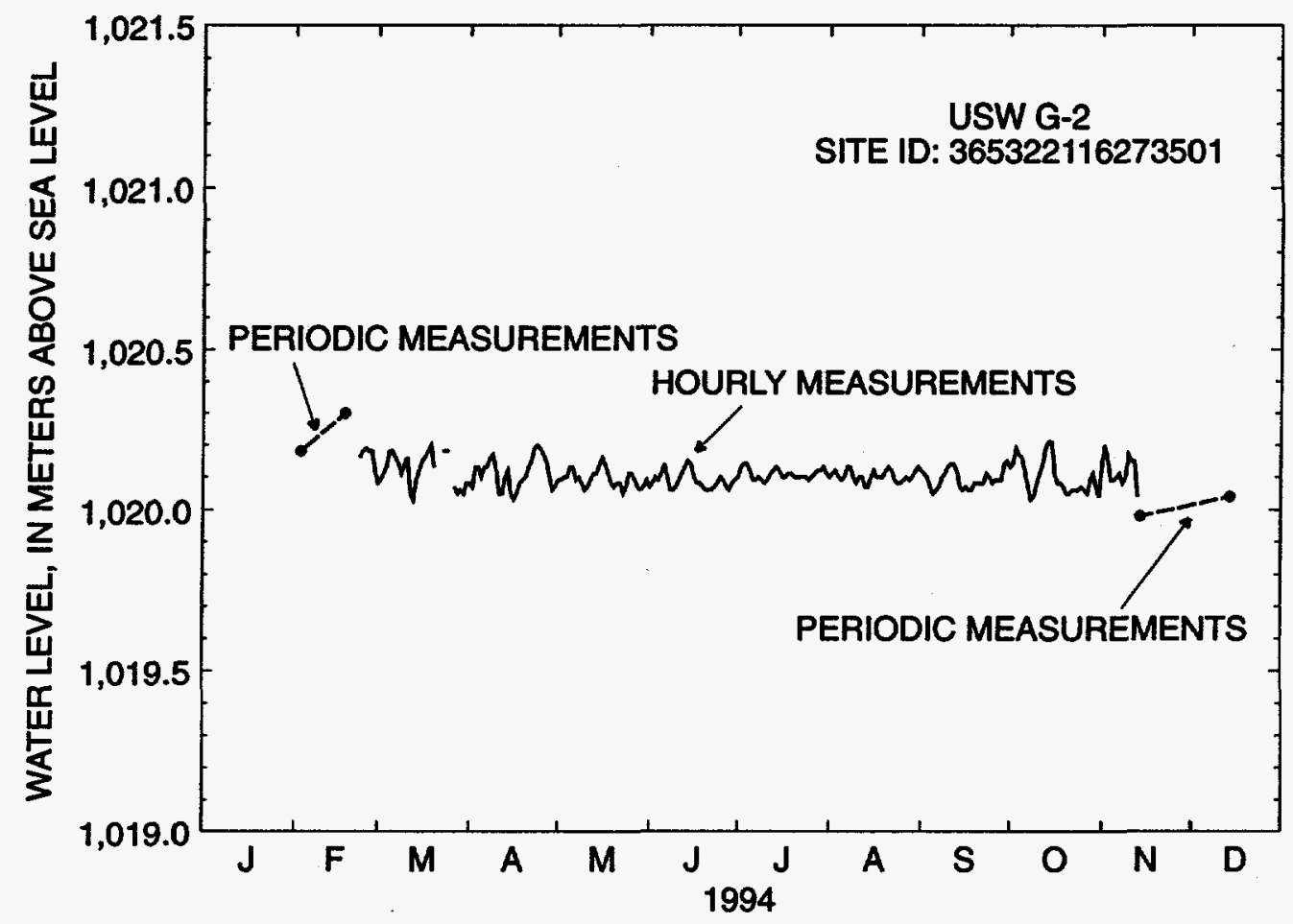

Figure 20. Water-level altitudes, 1994, for well USW G-2.

Table 13. Mean monthly water-level altitudes, 1994 , for well USW G-2

[Monthly means were calculated regardless of the number of days of missing data.

Daily means were not calculated if 6 or more consecutive hours of data were missing;

--, data not available; NA, not applicable, well not instrumented during this month]

\begin{tabular}{lcc}
\hline Month & $\begin{array}{c}\text { Water-level altitude } \\
\text { (meters, above } \\
\text { sea level) }\end{array}$ & $\begin{array}{c}\text { Number of missing } \\
\text { daily means }\end{array}$ \\
\hline January & --- & NA \\
February & $1,020.17$ & 22 \\
March & $1,020.12$ & 3 \\
April & $1,020.11$ & 0 \\
May & $1,020.09$ & 0 \\
June & $1,020.09$ & 0 \\
July & $1,020.11$ & 0 \\
August & $1,020.10$ & 0 \\
September & $1,020.09$ & 0 \\
October & $1,020.10$ & 0 \\
November & $1,020.12$ & 17 \\
December & --- & NA \\
\hline
\end{tabular}




\section{Well USW G-3}

Information about the history of well USW G-3 and about previous data from the well was obtained from various sources. These sources are: Robison (1984, 1986); Robison and others (1988); and Fenix \& Scisson, Inc. (1987b, 1987c).

\section{Well specifications}

1. Location and identification:

Latitude and longitude: $36^{\circ} 49^{\prime} 05^{\prime \prime} \mathrm{N}$.; $116^{\circ} 28^{\prime} 01^{\prime \prime} \mathrm{W}$.

Nevada State Central Zone Coordinates (m): N 229,447; E 170,226.

U.S. Geological Survey Site ID: 364905116280101.

2. Drilling and casing information:

Well started: January 8, 1982.

Well completed: March 21, 1982.

Drilling method: Rotary, using mostly air-foam, and occasional polymer added for circulating medium; many drilling problems encountered in upper part of hole, including lost circulation and lost or stuck tools; hole cored from $795 \mathrm{~m}$ to total drilled depth.

Bit diameter below water level: $222 \mathrm{~mm}$ to $792 \mathrm{~m} ; 121 \mathrm{~mm}$ from 792 to $795 \mathrm{~m} ; 100 \mathrm{~mm}$ from $795 \mathrm{~m}$ to total drilled depth.

Casing extending below water level: $126-\mathrm{mm}$ inside diameter to $792 \mathrm{~m}$; bottom casing tack cemented; no perforations.

Total drilled depth: $1,533 \mathrm{~m}$.

3. Access to and description of interval for measuring water levels:

Casing, 126-mm inside diameter, extending from land surface to a depth of $792 \mathrm{~m}$; saturated interval of borehole is within the Tram Tuff of the Crater Flat Group and the Lithic Ridge Tuff.

4. Information for calculating water-level altitude:

Reference point: Top of metal tag on well casing; altitude $1,480.47 \mathrm{~m}$ (surveyed by U.S. Geological Survey, 1984).

Measuring point: Top of access tube, $0.329 \mathrm{~m}$.

Depth correction for borehole deviation from vertical: $0.564 \mathrm{~m}$, based on approximate depth to water of $750 \mathrm{~m}$ (1990 data).

Well USW G-3 was measured periodically and hourly during 1994 . Hourly measurements were made until April 13, 1994; the day the transducer was removed from the well. During the period of hourly measurements one calibration of one transducer was performed. In addition, a calibration was completed on December 16, 1994. This calibration was used to calculate water-level altitudes at the beginning of 1994. Results of the calibration and measured water-level altitudes obtained during the calibration are as follows: 


\begin{tabular}{ccccc}
\hline $\begin{array}{c}\text { Transducer serial } \\
\text { number }\end{array}$ & Calibration date & $\begin{array}{c}\text { Slope } \\
\text { (meters/millivolt) }\end{array}$ & $\begin{array}{c}\text { Coefficient of } \\
\text { determination }\end{array}$ & $\begin{array}{c}\text { Water-level } \\
\text { altitude } \\
\text { (moters) }\end{array}$ \\
\hline 592472 & $12-16-93$ & 0.090 & 1.00 & 730.77 \\
592472 & $04-13-94$ & .090 & 1.00 & 730.53 \\
\hline
\end{tabular}

'Well USW G-3: All water-level measurements were made with the multiconductor cable unit.

All transducer data collected for USW G-3 for 1994 were considered to be valid.

Periodic measurements began on well USW G-3 on April 13, 1994 using the multiconductor cable unit and continued through the end of the year. The results of the periodic measurements on USW G-3 are as follows:

\begin{tabular}{ccc}
\hline Date & $\begin{array}{c}\text { Measured wator-level altitude } \\
\text { (meters, above sea level) }\end{array}$ & Mothod \\
\hline $04-13-94$ & 730.53 & Multiconductor cable unit \\
$05-31-94$ & 730.48 & Multiconductor cable unit \\
$06-24-94$ & 730.43 & Multiconductor cable unit \\
$07-20-94$ & 730.42 & Multiconductor cable unit \\
$08-17-94$ & 730.31 & Multiconductor cable unit \\
$09-14-94$ & 730.27 & Multiconductor cable unit \\
$10-24-94$ & 730.24 & Multiconductor cable unit \\
$12-01-94$ & 730.31 & Multiconductor cable unit \\
\hline
\end{tabular}

Water-level altitudes for well USW G-3 ranged from 730.24 to $730.80 \mathrm{~m}$ above sea level in 1994 (fig. 21). Mean monthly water-level altitudes for January through April 1994, are listed in table 14. The mean annual water-level altitude for 1994 was $730.64 \mathrm{~m}$ above sea level. This mean altitude was $0.07 \mathrm{~m}$ higher than the mean altitude of $730.57 \mathrm{~m}$ for 1993 (Tucci, Goemaat, and Burkhardt, 1996). 


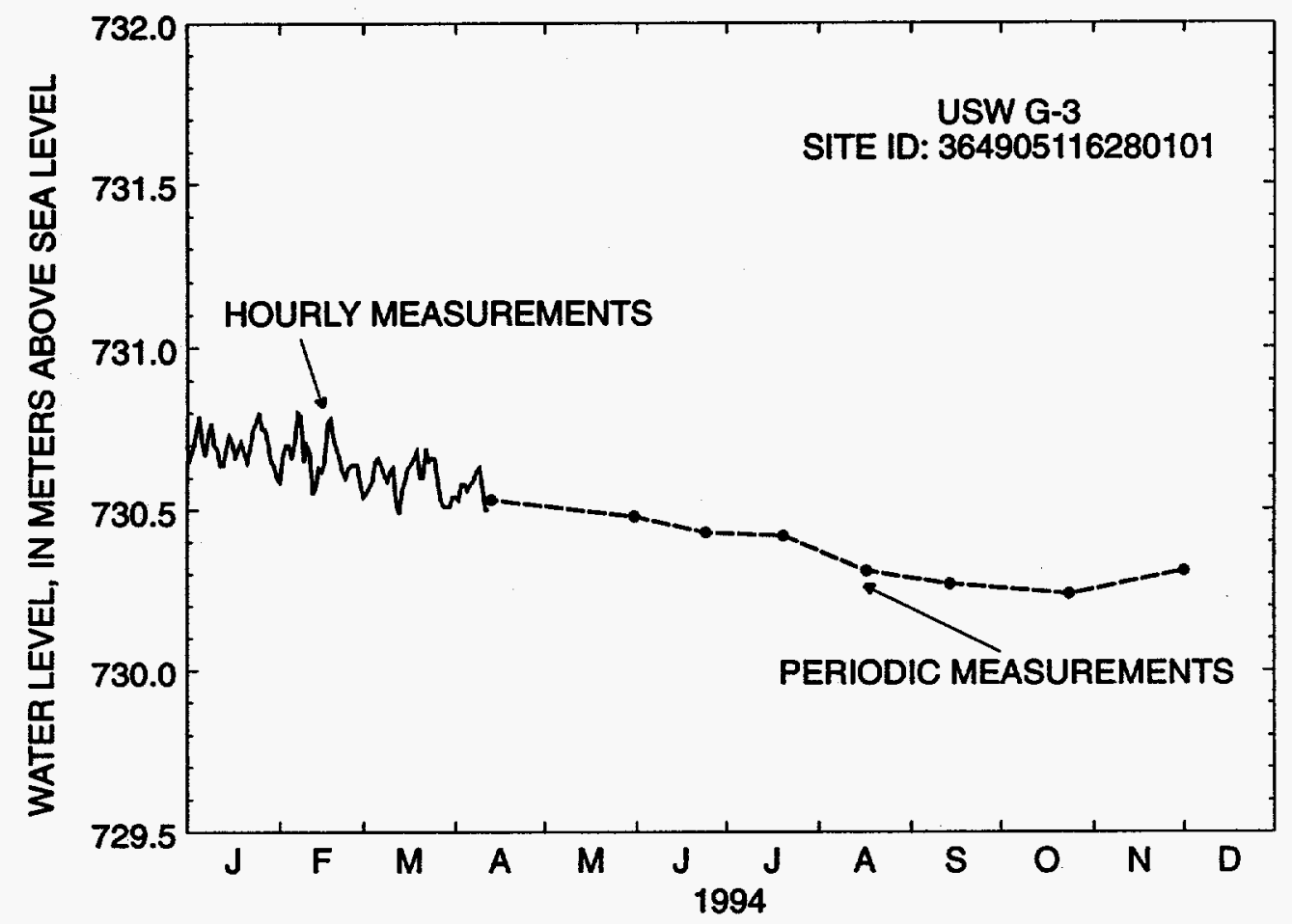

Figure 21. Water-level altitudes, 1994, for well USW G-3.

Table 14. Mean monthly water-level altitudes, 1994 , for well USW G-3

[Monthly means were calculated regardless of the number of days of missing data. Daily means were not calculated if 6 or more consecutive hours of data were missing;

--, data not available; NA, not applicable, well not instrumented during this month]

\begin{tabular}{lcc}
\hline Month & $\begin{array}{c}\text { Water-level altitude } \\
\text { (meters, above } \\
\text { sea level) }\end{array}$ & $\begin{array}{c}\text { Number of missing } \\
\text { daily means }\end{array}$ \\
\hline January & 730.70 & 0 \\
February & 730.67 & 0 \\
March & 730.60 & 0 \\
April & 730.56 & 18 \\
May & -- & NA \\
June & --- & NA \\
July & -- & NA \\
August & --- & NA \\
September & -- & NA \\
October & -- & NA \\
November & --- & NA \\
December & -- & NA \\
\hline
\end{tabular}




\section{Well USW H-1}

Information about the history of well USW H-1 and about previous data from the well was obtained from various sources. These sources are: Rush and others (1983); Rush and others (1984); Robison (1984, 1986); Robison and others (1988); and Fenix \& Scisson, Inc. (1987a, 1987c).

\section{Well specifications}

1. Location and identification:

Latitude and longitude: $36^{\circ} 51^{\prime} 57^{\prime \prime} \mathrm{N}$.; $116^{\circ} 27^{\prime} 12^{\prime \prime} \mathrm{W}$.

Nevada State Central Zone Coordinates (m): N 234,774; E 171,416.

U.S. Geological Survey Site ID: 365157116271201.

2. Drilling and casing information:

Well started: September 3, 1980.

Well completed: January 25, 1981 (initial completion, including geophysical logging and hydraulic testing); July 6, 1982 (re-completion; four piezometers installed).

Drilling method: Rotary, using rock bits and air-foam circulating medium; cores obtained from selected intervals.

Bit diameter below water level: $311 \mathrm{~mm}$ to $688 \mathrm{~m} ; 222 \mathrm{~mm}$ from $688 \mathrm{~m}$ to $1,829 \mathrm{~m}$.

Casing extending below water level: 226-mm inside diameter to $687 \mathrm{~m}$. Casing string is tack cemented and perforated below the water table. See section 3 for description of intervals open to water.

Total drilled depth: $1,829 \mathrm{~m}$.

3. Access to and description of interval for measuring water levels:

Tube 1:

44-mm inside diameter, that has a 3.6-m-long well screen on bottom, extending from land surface to depth of $1,806 \mathrm{~m}$; responds to depth interval from 1,783 to $1,814 \mathrm{~m}$ within older flows and tuffs beneath the Lithic Ridge Tuff;

Tube 2:

$44 \mathrm{~mm}$ inside diameter, that has a 3.6-m-long well screen on bottom, extending from land surface to depth of $1,115 \mathrm{~m}$; responds to depth interval from 1,097 to $1,123 \mathrm{~m}$ within the Tram Tuff of the Crater Flat Group, and lava flow and flow breccia beneath the Tram Tuff;

Tube 3:

44-mm inside diameter, that has a 3.6-m-long well screen on bottom, extending from land surface to depth of $741 \mathrm{~m}$; responds to depth interval from 716 to $765 \mathrm{~m}$ within the Bullfrog Tuff of the Crater Flat Group;

Tube 4:

62-mm inside diameter, open ended, extending from land surface to depth of $640 \mathrm{~m}$; responds to depth interval from 572 to $673 \mathrm{~m}$ within the Prow Pass Tuff of the Crater Flat Group.

Note: During re-completion, a gravel pack was placed in the vicinity of the well screens for tubes 1,2 , and 3; and other intervals were grouted with cement to ensure that the piezometers are hydraulically isolated from each other. 
4. Information for calculating water-level altitude:

Reference point: Top of metal tag on well casing; altitude $1,303.10 \mathrm{~m}$ (surveyed by U.S. Geological Survey, 1984).

Measuring point: Top of access tubes, $0.311 \mathrm{~m}$, all intervals.

Depth correction for borehole deviation from vertical: $0.143 \mathrm{~m}$ in tube 1 , based on approximate depth to water of $518 \mathrm{~m}$ (1990 data); $0.171 \mathrm{~m}$ in tube 2, based on approximate depth to water of $567 \mathrm{~m}$ (1993 data); $0.174 \mathrm{~m}$ in tubes 3 and 4, based on approximate depths to water of $572 \mathrm{~m}$ (1990 data).

Tube 1:

Well USW H-1, tube 1 was measured periodically during 1994. All measurements were made with Chain \#3 with the following results

\begin{tabular}{ccc}
\hline Date & $\begin{array}{c}\text { Measured water-level altitude } \\
\text { (meters, above sea level) }\end{array}$ & Method \\
\hline $01-31-94$ & 785.60 & Chain \#3 \\
$02-28-94$ & 785.62 & Chain \#3 \\
$03-15-94$ & 785.59 & Chain \#3 \\
$04-21-94$ & 785.71 & Chain \#3 \\
$05-12-94$ & 785.67 & Chain \#3 \\
$06-23-94$ & 785.78 & Chain \#3 \\
$07-27-94$ & 785.78 & Chain \#3 \\
$08-18-94$ & 785.88 & Chain \#3 \\
$09-27-94$ & 785.83 & Chain \#3 \\
$10-19-94$ & 785.89 & Chain \#3 \\
$11-09-94$ & 785.85 & Chain \#3 \\
$12-27-94$ & 785.73 & Chain \#3 \\
\hline
\end{tabular}

Water-level altitudes for well USW H-1, tube 1 ranged from 785.59 to $785.89 \mathrm{~m}$ above sea level in 1994 (fig. 22). The mean annual water-level altitude for 1994 was $785.74 \mathrm{~m}$ above sea level. This mean altitude was $0.16 \mathrm{~m}$ higher than the mean altitude of $785.58 \mathrm{~m}$ for 1993 (Tucci, Goemaat, and Burkhardt, 1996). 


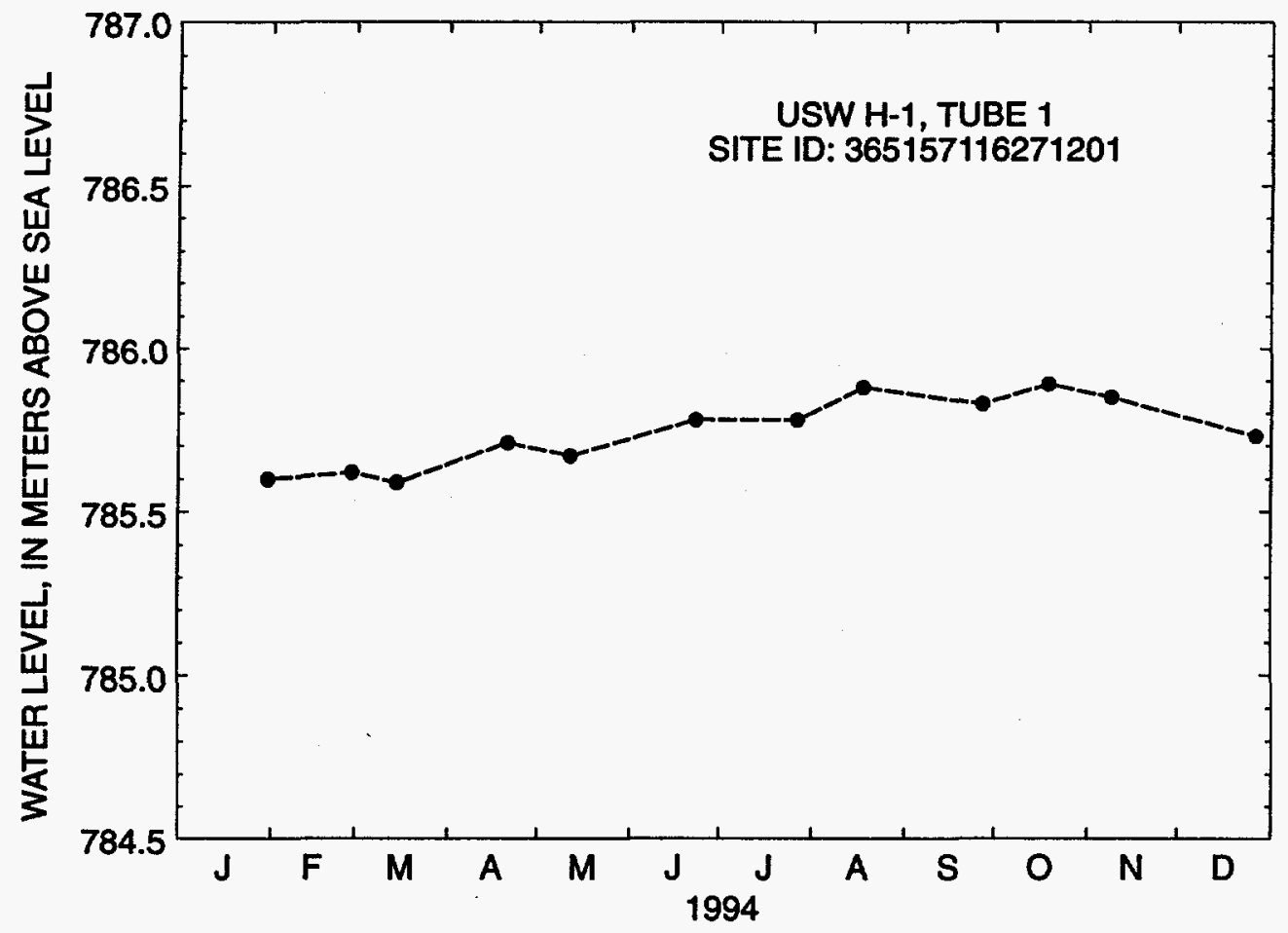

Figure 22. Water-level altitudes, 1994, for well USW H-1, tube 1.

Tube 2:

Well USW H-1, tube 2 was measured periodically during 1994. All measurements were made with Chain \#3 with the following results:

\begin{tabular}{ccc}
\hline Date & $\begin{array}{c}\text { Messured water-tevel altitude } \\
\text { (moters, above sea level) }\end{array}$ & Mothod \\
\hline $01-31-94$ & 735.84 & Chain \#3 \\
$02-28-94$ & 736.01 & Chain \#3 \\
$03-15-94$ & 736.02 & Chain \#3 \\
$04-21-94$ & 736.01 & Chain \#3 \\
$05-12-94$ & 735.90 & Chain \#3 \\
$06-23-94$ & 735.82 & Chain \#3 \\
$07-27-94$ & 735.80 & Chain \#3 \\
$07-28-94$ & 735.81 & Chain \#3 \\
$08-01-94$ & 735.82 & Chain \#3 \\
$08-18-94$ & 735.80 & Chain \#3 \\
$09-27-94$ & 735.77 & Chain \#3 \\
$11-09-94$ & 735.78 & Chain \#3 \\
$12-27-94$ & 735.75 & Chain \#3 \\
\hline
\end{tabular}


Water-level altitudes for well USW H-1, tube 2 ranged from 735.75 to $736.02 \mathrm{~m}$ above sea level in 1994 (fig. 23). The mean annual water-level altitude for 1994 was $735.86 \mathrm{~m}$ above sea level. This mean altitude was $0.08 \mathrm{~m}$ lower than the mean altitude of $735.94 \mathrm{~m}$ for 1993 (Tucci, Goemaat, and Burkhardt, 1996).

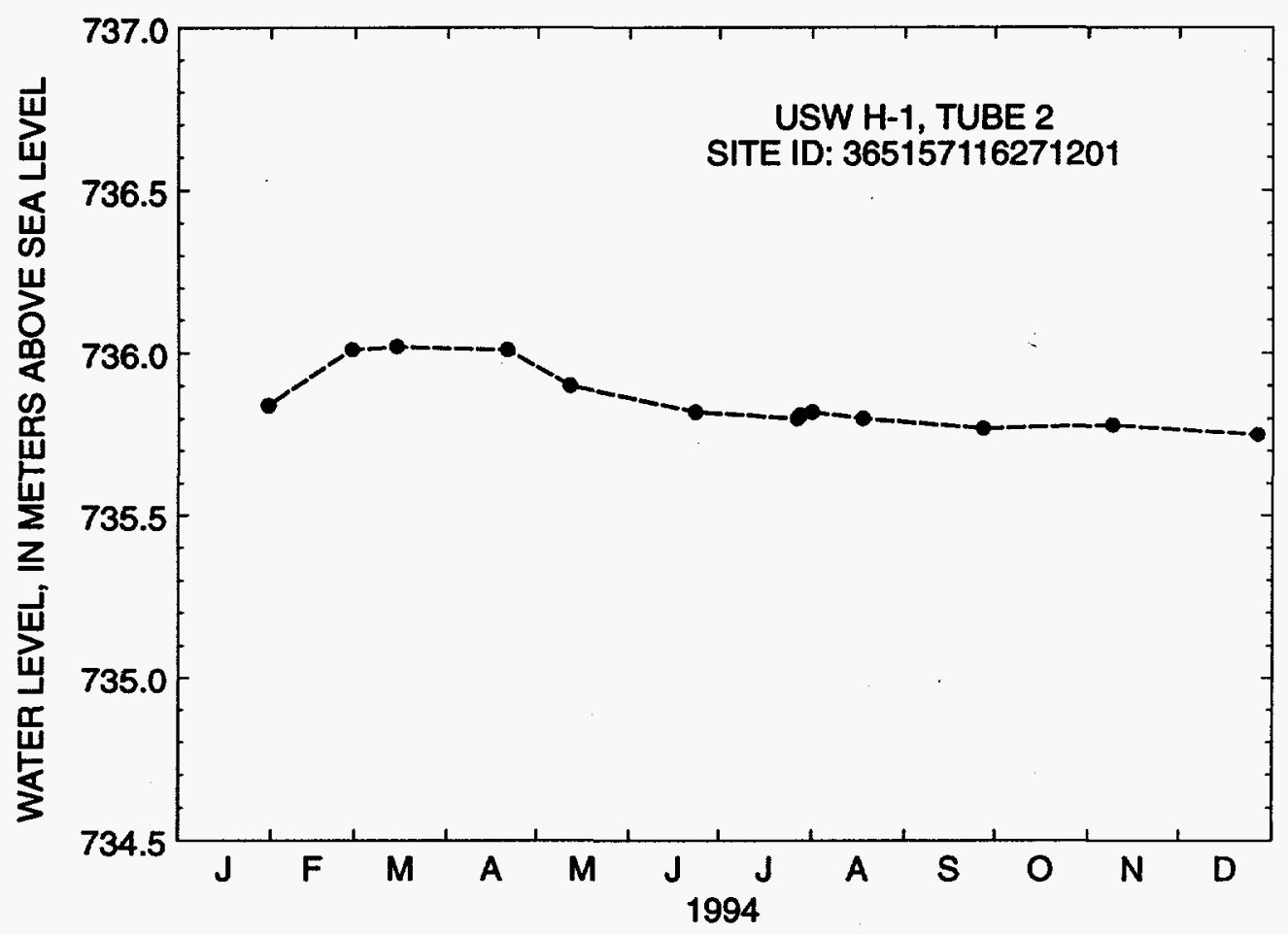

Figure 23. Water-level altitudes, 1994, for well USW H-1, tube 2.

Tube 3:

Well USW H-1, tube 3 was measured hourly during 1994. Six calibrations of two transducers were performed during 1994. in addition, calibrations on September 9, 1993, and April 11, 1995 were used to calculate water levels for 1994. Results of the calibration and measured water-level altitudes during the calibrations are as follows:

\begin{tabular}{ccccc}
\hline $\begin{array}{c}\text { Transducer sorial } \\
\text { number }\end{array}$ & Calibration date & $\begin{array}{c}\text { Slope } \\
\text { (metera/millivolt) }\end{array}$ & $\begin{array}{c}\text { Coefficiont of } \\
\text { determination }\end{array}$ & $\begin{array}{c}\text { Water-level } \\
\text { altitude }^{1} \\
\text { (meters) }\end{array}$ \\
\hline 255373 & $09-09-93$ & 0.088 & 1.00 & 730.59 \\
255373 & $01-07-94$ & .087 & 1.00 & 730.70 \\
255373 & $03-02-94$ & .087 & 0.99 & 730.54 \\
567096 & $03-02-94$ & .085 & 0.99 & 730.54 \\
567096 & $07-07-94$ & .088 & 1.00 & 730.52 \\
567096 & $10-19-94$ & .089 & 0.99 & 730.50 \\
567096 & $12-20-94$ & .086 & 0.99 & 730.63 \\
567096 & $04-11-95$ & .089 & 0.99 & 730.59 \\
\hline
\end{tabular}

${ }^{1}$ Well USW H-1, tube 3: The water-level measurements made on January 7, March 2, and

December 20,1994, were made with Chain \#3. All other water-level measurements were made by tagging the water-surface with the transducer that was being calibrated. 
Data were removed on February 8, 9, 26, 27, 28, and March 1, 1994, partial data were removed on March 2, 1994. These data were removed due to a defective transducer which was replaced on March 2, 1994. Electronic spikes were removed from the record on February 11 and 13, 1994. These spikes were due to the defective transducer. All other transducer data collected for 1994 were considered to be valid.

Water-level altitudes for well USW H-1, tube 3 ranged from 730.45 to $730.82 \mathrm{~m}$ above sea level in 1994 (fig. 24). Mean monthly water-level altitudes are listed in table 15 . The mean annual water-level altitude for 1994 was $730.58 \mathrm{~m}$ above sea level. This mean altitude was $0.06 \mathrm{~m}$ lower than the mean altitude of $730.64 \mathrm{~m}$ for 1993 (Tucci, Goemaat, and Burkhardt, 1996).

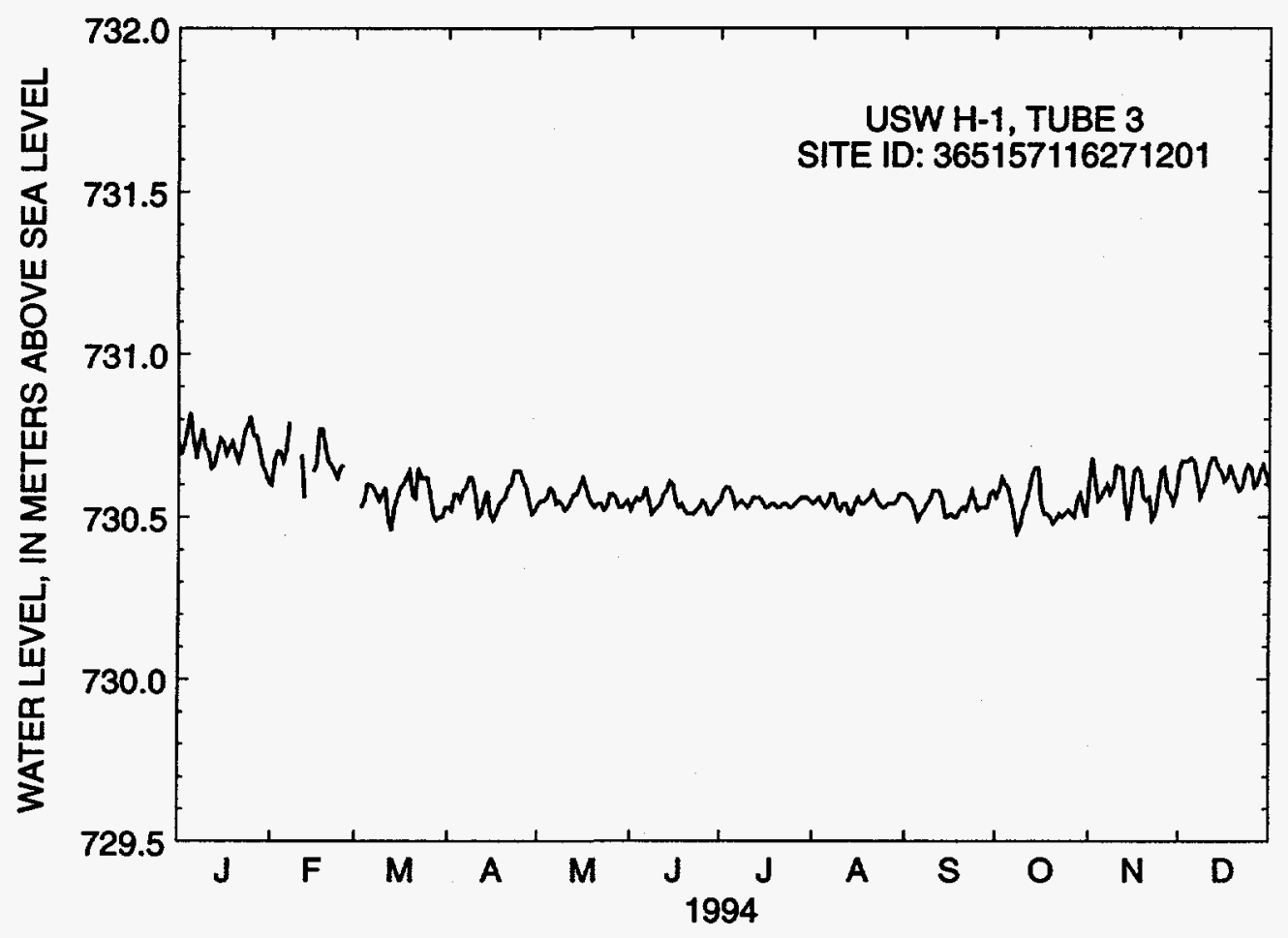

Figure 24. Water-level altitudes, 1994, for well USW H-1, tube 3.

Table 15. Mean monthly water-level altitudes, 1994, for well USW H-1, tube 3

[Monthly means were calculated regardless of the number of days of missing data. Daily means were not calculated if 6 or more consecutive hours of data were missing. For this well, daily means not calculated for February 10 and 14, 1994, because previous day's midnight reading was removed]

\begin{tabular}{lcc}
\hline Month & $\begin{array}{c}\text { Water-level altitude } \\
\text { (moters, above sea lovel) }\end{array}$ & $\begin{array}{c}\text { Number of missing } \\
\text { dally means }\end{array}$ \\
\hline January & 730.72 & 0 \\
February & 730.68 & 8 \\
March & 730.56 & 2 \\
April & 730.56 & 0 \\
May & 730.55 & 0 \\
June & 730.54 & 0 \\
July & 730.55 & 0 \\
August & 730.54 & 0 \\
September & 730.54 & 0 \\
October & 730.54 & 0 \\
November & 730.59 & 0 \\
December & 730.63 & 0 \\
\hline
\end{tabular}


Tube 4:

Well USW H-1, tube 4 was measured hourly during 1994. Six calibrations of two transducers were performed during 1994. In addition, calibrations on September 9, 1993 and April 11, 1995, were used to calculate water levels for 1994. Results of the calibrations and measured water-level altitudes obtained during the calibrations are as follows:

\begin{tabular}{ccccc}
\hline $\begin{array}{c}\text { Transducer } \\
\text { serial number }\end{array}$ & Calibration date & $\begin{array}{c}\text { Slope } \\
\text { (meters/millivolt) }\end{array}$ & $\begin{array}{c}\text { Coefficient of } \\
\text { determination }\end{array}$ & $\begin{array}{c}\text { Water-level } \\
\text { altitude } \\
\text { (meters) }\end{array}$ \\
\hline $2656 \mathrm{DJ}$ & $09-09-93$ & 0.089 & 1.00 & 730.88 \\
$2656 \mathrm{DJ}$ & $01-06-94$ & .091 & 1.00 & 730.83 \\
$2656 \mathrm{DJ}$ & $05-04-94$ & .094 & 0.99 & 730.84 \\
$2656 \mathrm{DJ}$ & $07-07-94$ & .091 & 1.00 & 730.82 \\
$2656 \mathrm{DJ}$ & $09-01-94$ & .256 & 1.00 & 730.86 \\
621310 & $09-01-94$ & .090 & 1.00 & 730.86 \\
621310 & $12-20-94$ & .090 & 1.00 & 730.87 \\
621310 & $04-11-95$ & .089 & 1.00 & 730.88 \\
\hline
\end{tabular}

${ }^{1}$ Well USW H-1, tube 4: The water-level measurements made on January 6 and September 1, 1994, were made with Chain \#3. All other water-level measurements were made by tagging the water-surface with the transducer that was being calibrated.

Data were removed from August 4 until September 1, 1994. The transducer was losing its sensitivity and was replaced on September 1, 1994. Spikes were removed on May 2 and 4, June 12, 13, 14, and 16, September 23, and December 28, 1994. The reason for the spikes are not known. Partial data were collected August 3, 1994, because of the loss of transducer sensitivity. A daily mean was not calculated for December 20,1994, because the calibration of the well on this date took longer than 6 hours. All other transducer data collected for 1994 were considered to be valid.

Water-level altitudes for well USW H-1, tube 4 ranged from 730.75 to $730.99 \mathrm{~m}$ above sea level in 1994 (fig. 25). Mean monthly water-level altitudes are listed in table 16. The mean annual water-level altitude for 1994 was $730.87 \mathrm{~m}$ above sea level. This mean altitude was $0.03 \mathrm{~m}$ lower than the mean altitude of $730.90 \mathrm{~m}$ for 1993 (Tucci, Goemaat, and Burkhardt, 1996). 


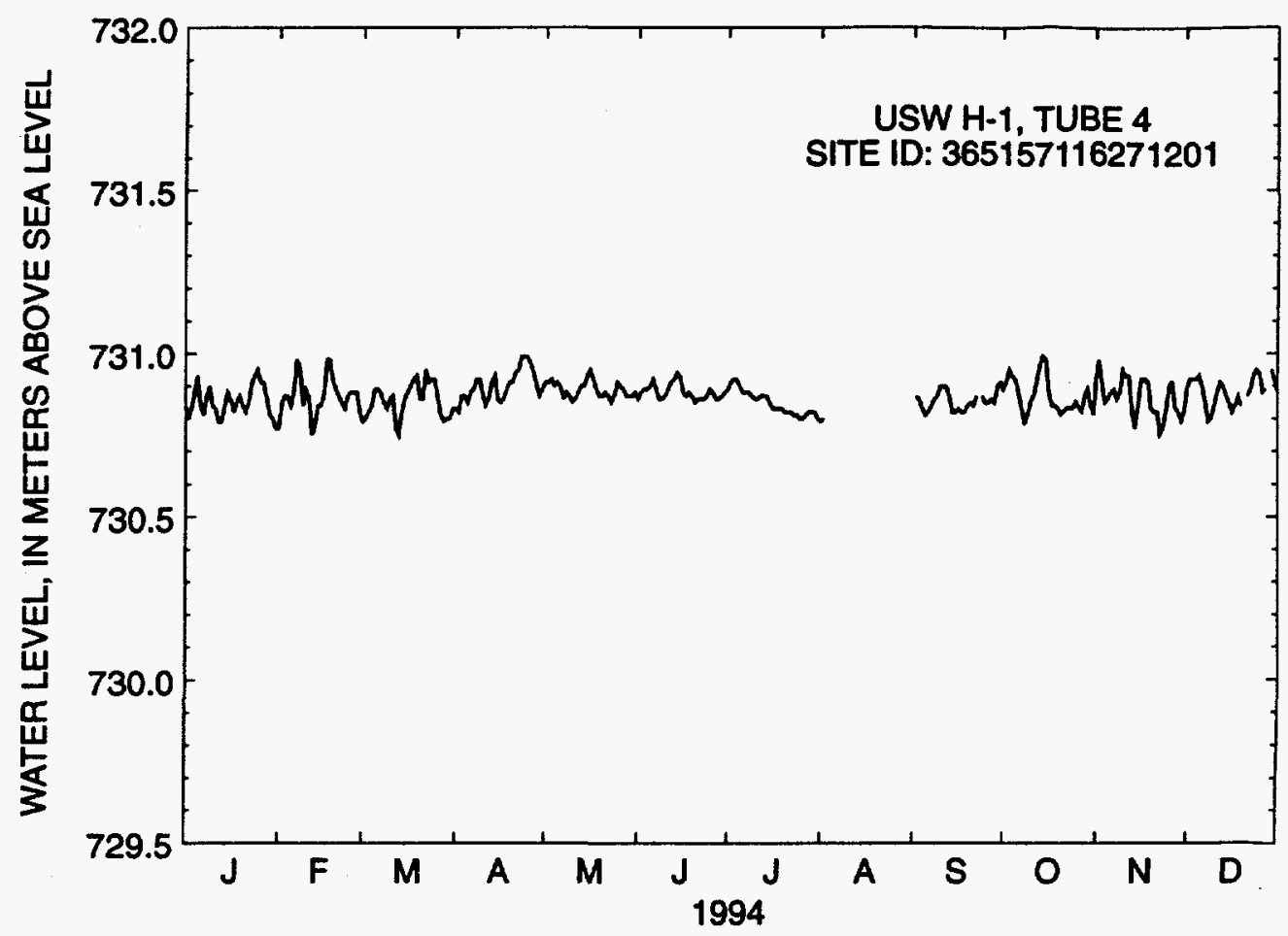

Figure 25. Water-level altitudes, 1994, for well USW H-1, tube 4.

Table 16. Mean monthly water-level altitudes, 1994, for well USW H-1, tube 4

[Monthly means were calculated regardless of the number of days of missing data. Daily means were not calculated if 6 or more consecutive hours of data were missing]

\begin{tabular}{lcc}
\hline Month & $\begin{array}{c}\text { Water-lovel altitude } \\
\text { (meters, above } \\
\text { sea level) }\end{array}$ & $\begin{array}{c}\text { Number of missing } \\
\text { daily means }\end{array}$ \\
\hline January & 730.85 & 0 \\
February & 730.87 & 0 \\
March & 730.85 & 0 \\
April & 730.90 & 0 \\
May & 730.89 & 0 \\
June & 730.88 & 0 \\
July & 730.85 & 0 \\
August & 730.80 & 29 \\
September & 730.85 & 2 \\
October & 730.87 & 0 \\
November & 730.86 & 0 \\
December & 730.88 & 2 \\
\hline
\end{tabular}




\section{Well IUSW H-3}

Information about the history of well USW H-3 and about previous data from the well was obtained from various sources. These sources are: Thordarson, Rush, Spengler, and Waddell (1984); Thordarson, Rush, and Waddell (1984); Robison (1984, 1986); Robison and others (1988); and Fenix \& Scisson, Inc. (1987a, 1987c).

Well specifications

1. Location and identification:

Latitude and longitude: $36^{\circ} 49^{\prime} 42^{\prime \prime} \mathrm{N}$.; $116^{\circ} 28^{\prime} 00^{\prime \prime} \mathrm{W}$.

Nevada State Central Zone Coordinates (m): N 230,594; E 170,216.

U.S. Geological Survey Site ID: 364942116280001.

2. Drilling and casing information:

Well started: January 27, 1982.

Well completed: March 19, 1982.

Drilling method: Rotary, using rock bits and air-foam circulating medium.

Bit diameter below water level: $375 \mathrm{~mm}$ to $808 \mathrm{~m} ; 222 \mathrm{~m}$ from $808 \mathrm{~m}$ to $1,219 \mathrm{~m}$.

Casing extending below water level: $253 \mathrm{~mm}$ diameter to $792 \mathrm{~m}$, not perforated below the water level.

Total drilled depth: $1,219 \mathrm{~m}$.

3. Access to and description of intervals for measuring water levels:

Upper interval:

41-mm inside diameter open ended tubing, extending from land surface to depth of about $762 \mathrm{~m}$; upper interval of well, from near water table to top of inflatable packer, is within bedded tuff and the Tram Tuff of the Crater Flat Group;

Lower interval:

62-mm inside diameter tubing that has an inflatable packer on bottom end extending from land surface to $1,114 \mathrm{~m}$; lower interval from below packer to bottom of well, is within the Lithic Ridge Tuff.

Note: Inflatable packer installed January 1983 at a depth of $1,190 \mathrm{~m}$; removed late November 1983 during period of additional hydraulic testing; re-installed in May 1984 at depth of 1,114 m.

4. Information for calculating water-level altitude:

Reference point: Top of metal tag on well casing; altitude $1483.47 \mathrm{~m}$ (surveyed by U.S. Geological Survey, 1984).

Measuring point: Top of access tubes, $0.174 \mathrm{~m}$, upper interval; $0.201 \mathrm{~m}$, lower interval.

Depth correction for borehole deviation from vertical: $0.079 \mathrm{~m}$, upper interval, based on approximate depth to water of $752 \mathrm{~m}$ (1990 data); $0.058 \mathrm{~m}$, lower interval, based on approximate depth to water of $728 \mathrm{~m}$ (1990 data).

Well USW H-3, upper interval was measured hourly during 1994. Four calibrations of two transducers were performed during 1994. In addition, calibrations on November 23, 1993, and April 20, 1995 , were used to calculate water levels for 1994. Results of the calibrations and measured water-level altitudes obtained during the calibrations are as follows: 


\begin{tabular}{ccccc}
\hline $\begin{array}{c}\text { Transducer serial } \\
\text { number }\end{array}$ & Calibration date & $\begin{array}{c}\text { Slope } \\
\text { (meters/milivolt) }\end{array}$ & $\begin{array}{c}\text { Coefficient of } \\
\text { determination }\end{array}$ & $\begin{array}{c}\text { Water-level } \\
\text { altitude }^{1} \\
\text { (meters) }\end{array}$ \\
\hline 264709 & $11-23-93$ & 0.090 & 1.00 & 731.28 \\
264709 & $03-22-94$ & .090 & 1.00 & 731.33 \\
264709 & $07-20-94$ & .089 & 1.00 & 731.25 \\
621315 & $07-21-94$ & .089 & 1.00 & 731.26 \\
621315 & $12-07-94$ & .089 & 1.00 & 731.22 \\
621315 & $04-20-95$ & .089 & 1.00 & 731.35 \\
\hline
\end{tabular}

${ }^{1}$ Well USW H-3, upper interval: The water-level measurements made on July 20 and 21,1994 , were made with Chain \#3. All other water-level measurements were made by tagging the water-surface with the transducer that was being calibrated.

Data were removed for May 23 and 24, 1994; low battery voltage resulted in poor data for these two days. Data are missing for June 1, 1994, because of loss of power at the site. Data are missing for July 20 and 21, 1994, because the transducer was removed and replaced on these days. A daily mean was not calculated for December 7,1994 , because the calibration of the well on this date took longer than 6 hours. All other transducer data collected for 1994 were considered to be valid.

Water-level altitudes for well USW H-3, upper interval ranged from 731.11 to $731.35 \mathrm{~m}$ above sea level in 1994 (fig. 26). Mean monthly water-level altitudes are listed in table 17. The mean annual waterlevel altitude for 1994 was $731.24 \mathrm{~m}$ above sea level. This mean altitude was $0.03 \mathrm{~m}$ higher than the mean altitude of $731.21 \mathrm{~m}$ for 1993 (Tucci, Goemaat, and Burkhardt, 1996).

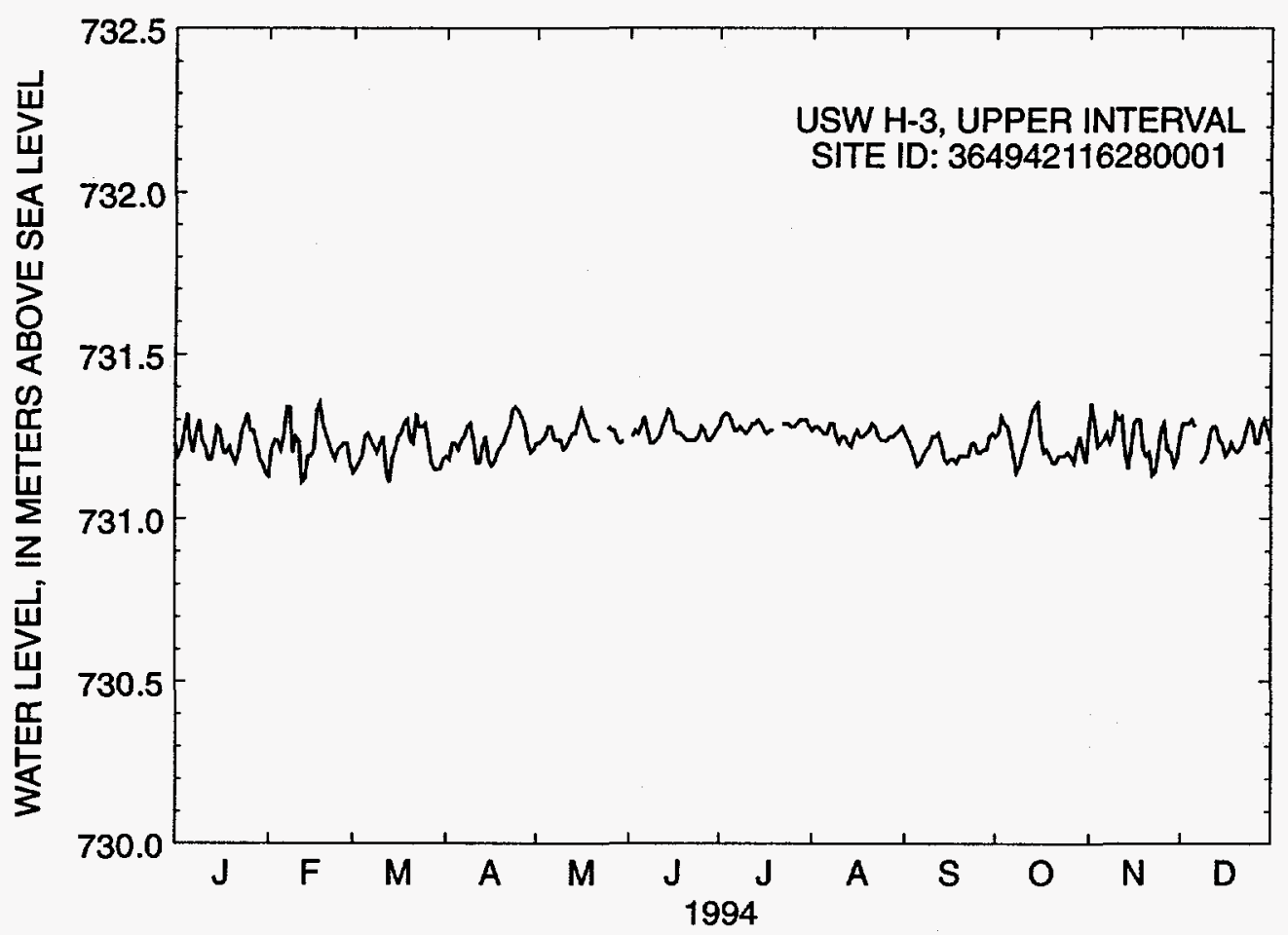

Figure 26. Water-level altitudes, 1994, for well USW H-3, upper interval. 
Table 17. Mean monthly water-level altitudes, 1994, for well USW H-3, upper interval

[Monthly means were calculated regardless of the number of days of missing data. Daily means were not calculated if 6 or more consecutive hours of data were missing]

\begin{tabular}{lcc}
\hline Month & $\begin{array}{c}\text { Water-level altitude } \\
\text { (meters, above } \\
\text { sea level) }\end{array}$ & $\begin{array}{c}\text { Number of missing } \\
\text { daily means }\end{array}$ \\
\hline January & 731.23 & 0 \\
February & 731.23 & 0 \\
March & 731.22 & 0 \\
April & 731.24 & 0 \\
May & 731.25 & 2 \\
June & 731.26 & 1 \\
July & 731.29 & 2 \\
August & 731.26 & 0 \\
September & 731.21 & 0 \\
October & 731.23 & 0 \\
November & 731.24 & 0 \\
December & 731.25 & 1 \\
\hline
\end{tabular}

Well USW H-3, lower interval was measured hourly during 1994. Four calibrations of two transducers were performed during 1994. In addition, calibrations on November 23, 1993, and April 20, 1995, were used to calibrate water levels for 1994 . Results of the calibrations and measured water-level altitudes obtained during the calibrations are as follows:

\begin{tabular}{ccccc}
\hline $\begin{array}{c}\text { Transducer serial } \\
\text { number }\end{array}$ & Calibration date & $\begin{array}{c}\text { Slope } \\
\text { (meters/millivolt) }\end{array}$ & $\begin{array}{c}\text { Coefficient of } \\
\text { determination }\end{array}$ & $\begin{array}{c}\text { Water-level } \\
\text { altitude } \\
\text { (meters) }\end{array}$ \\
\hline 264707 & $11-23-93$ & 0.087 & 1.00 & 757.45 \\
264707 & $03-22-94$ & .087 & 1.00 & 757.87 \\
264707 & $07-20-94$ & .088 & 1.00 & 758.21 \\
621282 & $07-21-94$ & .088 & 1.00 & 758.29 \\
621282 & $12-07-94$ & .088 & 1.00 & 758.69 \\
621282 & $04-20-95$ & .088 & 1.00 & 759.22 \\
\hline
\end{tabular}

${ }^{1}$ Well USW H-3, lower interval: The water-level measurements made on November 23, 1993, and July 20 and 21,1994 , were made with Chain \#3. The water-level measurement made on December 7,1994 , was made with the 2,800 -foot reference steel tape. All other water-level measurements were made by tagging the water-surface with the transducer that was being calibrated.

Data were removed for May 23 and 24, 1994; low battery voltage resulted in poor data for these two days. Data are missing for June 1,1994, because of loss of power at the site. Data are missing for July 20 and 21, 1994, because the transducer was removed and replaced on these days. A daily mean was not calculated for December 7, 1994, because the calibration of the well on this date took longer than 6 hours. All other transducer data collected for 1994 were considered to be valid. 
Water-level altitudes for well USW H-3, lower interval ranged from 757.45 to $758.84 \mathrm{~m}$ above sea level in 1994 (fig. 27). Mean monthly water-level altitudes are listed in table 18. The mean annual waterlevel altitude for 1994 was $758.18 \mathrm{~m}$ above sea level. This mean altitude was $1.35 \mathrm{~m}$ higher than the mean altitude of $756.83 \mathrm{~m}$ for 1993 (Tucci, Goemaat, and Burkhardt, 1996). The inflatable packer, which divides the well into two intervals, was moved to a different location on December 14, 1990. The water level in the lower interval has been rising, in the process of reaching equilibration, to a new static waterlevel since that time.

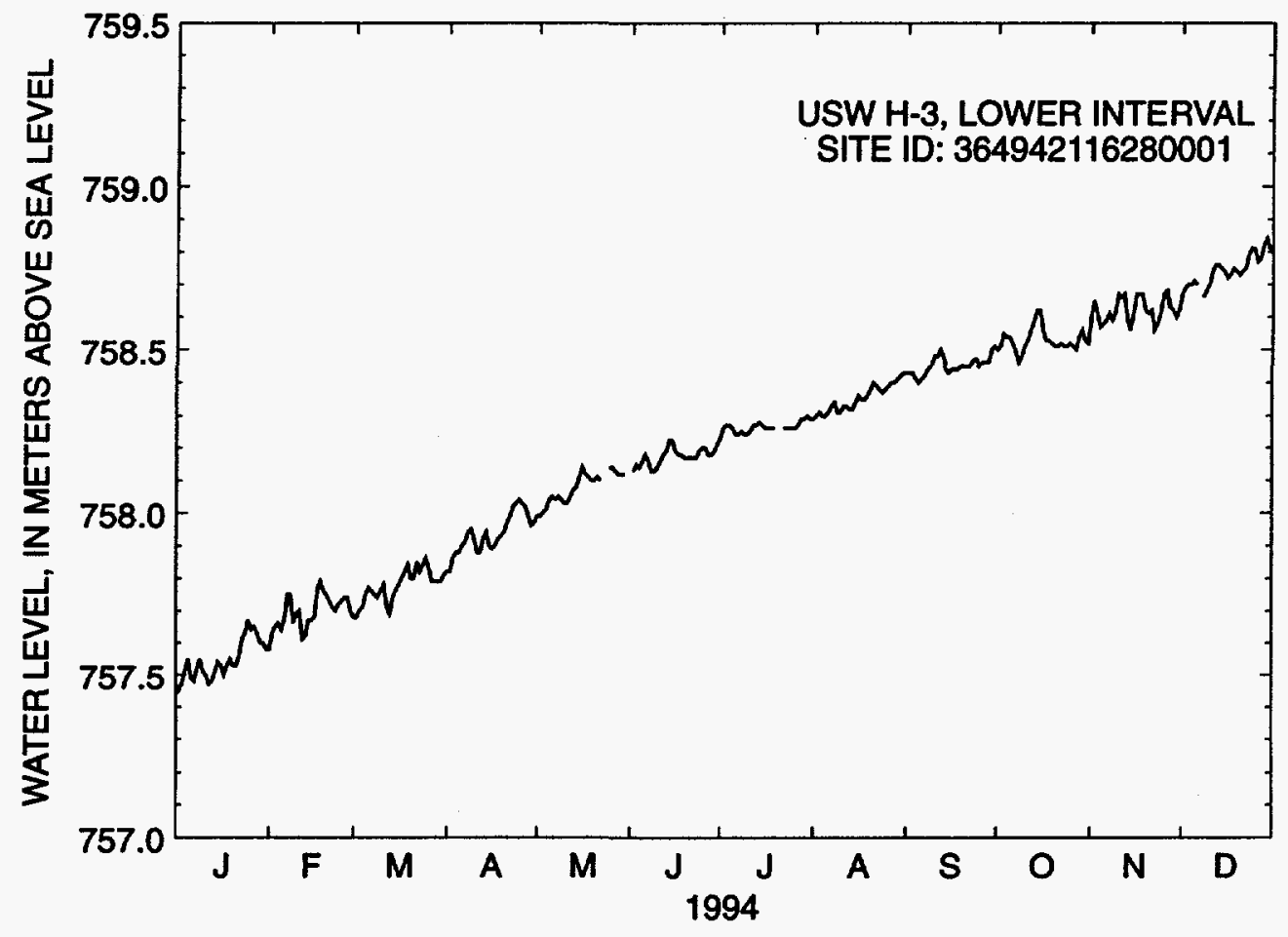

Figure 27. Water-level altitudes, 1994, for well USW H-3, lower interval.

Table 18. Mean monthly water-level altitudes, 1994, for well USW H-3, lower interval

[Monthly means were calculated regardless of the number of days of missing data. Daily means were not calculated if 6 or more consecutive hours of data were missing]

\begin{tabular}{lcc}
\hline Month & $\begin{array}{c}\text { Water-level altitude } \\
\text { (moters, above sea level) }\end{array}$ & $\begin{array}{c}\text { Number of missing } \\
\text { dailly moans }\end{array}$ \\
\hline January & 757.54 & 0 \\
February & 757.70 & 0 \\
March & 757.77 & 0 \\
April & 757.93 & 0 \\
May & 758.08 & 2 \\
June & 758.17 & 1 \\
July & 758.26 & 2 \\
August & 758.35 & 0 \\
September & 758.45 & 0 \\
October & 758.53 & 0 \\
November & 758.62 & 0 \\
December & 758.74 & 1 \\
\hline
\end{tabular}




\section{Well USW H-4}

Information about the history of well USW H-4 and about previous data from the well was obtained from various sources. These sources are: Whitfield and others (1984); Whitfield and others (1985); Robison (1984, 1986); Robison and others (1988); Erickson and Waddell (1985); and Fenix \& Scisson, Inc. $(1987 \mathrm{a}, 1987 \mathrm{c})$.

Well specifications

1. Location and identification:

Latitude and longitude: $36^{\circ} 50^{\prime} 32^{\prime \prime N}$.; $116^{\circ} 26^{\prime} 54^{\prime \prime} \mathrm{W}$.

Nevada State Central Zone Coordinates (m): N 232,149; E 171,880.

U.S. Geological Survey Site ID: 365032116265401.

2. Drilling and casing information:

Well started: March 22, 1982.

Well completed: June 7, 1982.

Drilling method: Rotary, using rock bits and air-foam circulating medium; cores obtained from selected intervals.

Bit diameter below water level: $375 \mathrm{~mm}$ to $564 \mathrm{~m} ; 222 \mathrm{~mm}$ from $564 \mathrm{~m}$ to $1,219 \mathrm{~m}$.

Casing extending below water level: $253 \mathrm{~mm}$ diameter to $561 \mathrm{~m}$, perforated below the water level.

Total drilled depth: $1,219 \mathrm{~m}$.

3. Access to and description of interval for measuring water levels:

\section{Upper interval:}

48-mm inside diameter open-ended tubing, extending from land surface to depth of $525 \mathrm{~m}$; upper interval of well near water table to top of inflatable packer is within the Prow Pass, Bullfrog, and Tram Tuffs of the Crater Flat Group, bedded tuff, and upper Lithic Ridge Tuff;

\section{Lower interval:}

62-mm inside diameter tubing with inflatable packer on bottom end, extending from surface to $1,188 \mathrm{~m}$; lower interval of well is within the Lithic Ridge Tuff.

4. Information for calculating water-level altitude:

Reference point: Top of metal tag on well casing; altitude $1,248.74 \mathrm{~m}$ (surveyed by U.S. Geological Survey, 1984).

Measuring point: Top of access tubes, $0.597 \mathrm{~m}$, upper interval; $0.308 \mathrm{~m}$, lower interval.

Depth correction for borehole deviation from vertical: $0.064 \mathrm{~m}$, based on approximate depth to water of $518 \mathrm{~m}$ (1990 data).

Well USW H-4, upper interval was measured hourly during 1994. Four calibrations of two transducers were performed during 1994. In addition, calibrations on November 30, 1993, and February 15, 1995 , were used to calculate water levels for 1994. Results of the calibrations and measured water-level altitudes obtained during the calibrations are as follows: 


\begin{tabular}{ccccc}
\hline $\begin{array}{c}\text { Transducer serlal } \\
\text { number }\end{array}$ & Calibration date & $\begin{array}{c}\text { Slope } \\
\text { (metera/millivolt) }\end{array}$ & $\begin{array}{c}\text { Coefficlent of } \\
\text { determination }\end{array}$ & $\begin{array}{c}\text { Water-level } \\
\text { attitude' } \\
\text { (meters) }\end{array}$ \\
\hline 365013 & $11-30-93$ & 0.090 & 1.00 & 730.46 \\
365013 & $03-30-94$ & .090 & 1.00 & 730.31 \\
592474 & $03-30-94$ & .090 & 1.00 & 730.31 \\
592474 & $07-26-94$ & .089 & 1.00 & 730.37 \\
592474 & $11-15-94$ & .089 & 1.00 & 730.38 \\
592474 & $02-15-95$ & .089 & 1.00 & 730.38 \\
\hline
\end{tabular}

${ }^{1}$ Well USW H-4, upper interval: The water-level measurements made on March 30, 1994, and February 15, 1995, were made with Chain \#3. All other water-level measurements were made by tagging the water-surface with the transducer that was being calibrated.

A daily mean was not calculated for July 26,1994 , because the calibration of the well on this date took longer than 6 hours. Spikes were removed from the data on December 8, 11, 12, 13, and 14, 1994. The site was visited on December 13 and 14 and work conducted during the visits could be the cause of the spikes on these two days; however, for the remaining days the cause of the spikes is not known. All other transducer data collected for 1994 were considered to be valid.

Water-level altitudes for well USW H-4, upper interval ranged from 730.29 to $730.55 \mathrm{~m}$ above sea level in 1994 (fig. 28). Mean monthly water-level altitudes are listed in table 19. The mean annual waterlevel altitude for 1994 was $730.39 \mathrm{~m}$ above sea level. This mean altitude was $0.14 \mathrm{~m}$ lower than the mean altitude of $730.53 \mathrm{~m}$ for 1993 (Tucci, Goemaat, and Burkhardt, 1996).

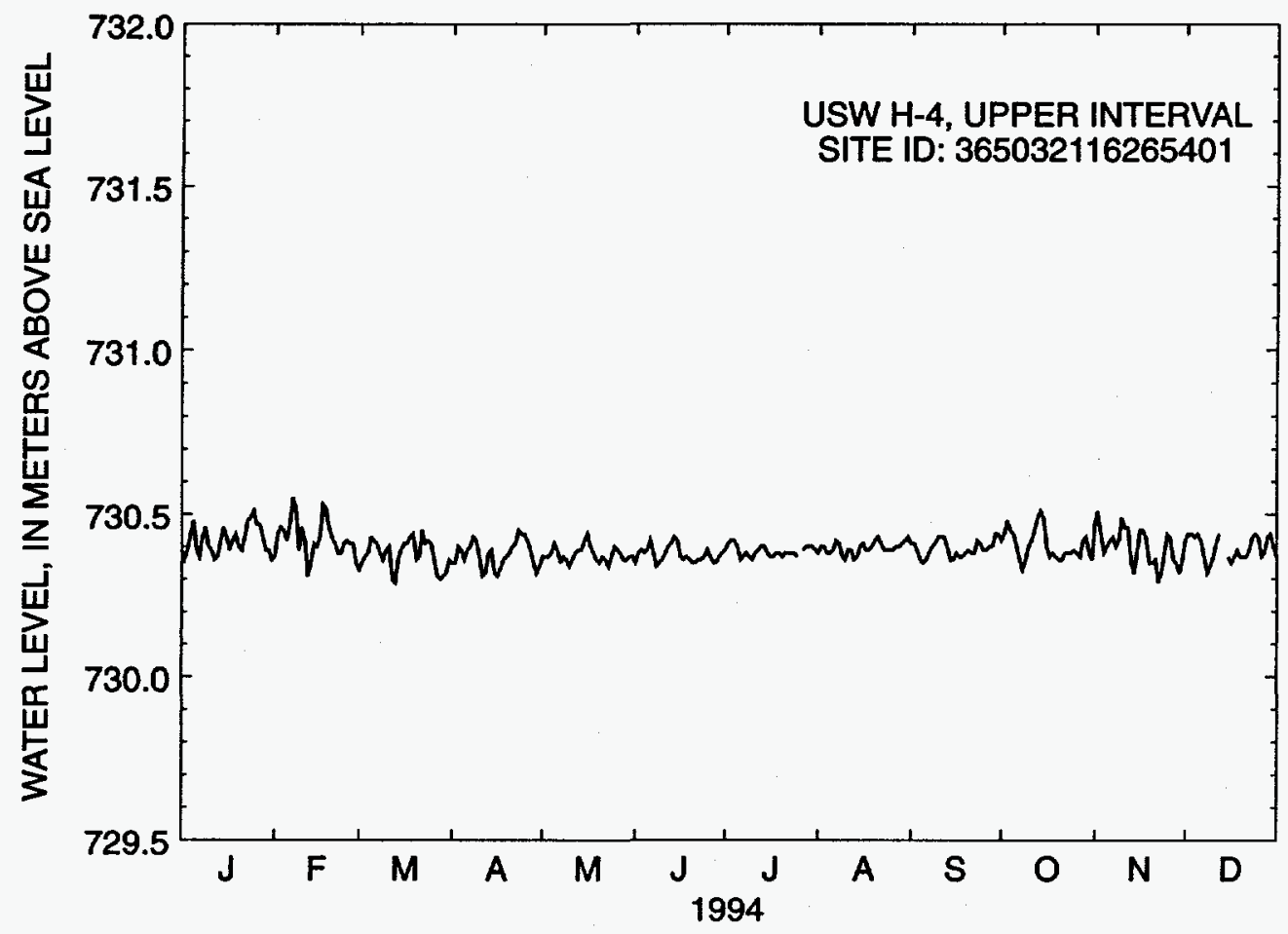

Figure 28. Water-level altitudes, 1994, for well USW H-4, upper interval. 
Table 19. Mean monthly water-level altitudes, 1994, for well USW H-4, upper interval

[Monthly means were calculated regardless of the number of days of missing data.

Daily means were not calculated if 6 or more consecutive hours of data were missing]

\begin{tabular}{lcc}
\hline Month & $\begin{array}{c}\text { Water-level alitide } \\
\text { (meters, above } \\
\text { sea lovel) }\end{array}$ & $\begin{array}{c}\text { Number of missing } \\
\text { daily means }\end{array}$ \\
\hline January & 730.42 & 0 \\
February & 730.43 & 0 \\
March & 730.38 & 0 \\
April & 730.38 & 0 \\
May & 730.38 & 0 \\
June & 730.37 & 0 \\
July & 730.39 & 1 \\
August & 730.40 & 0 \\
September & 730.39 & 0 \\
October & 730.40 & 0 \\
November & 730.40 & 0 \\
December & 730.40 & 2 \\
\hline
\end{tabular}

Well USW H-4, lower interval was measured hourly during 1994. Three calibrations of two transducers were performed during 1994. In addition, calibrations on December 28, 1993, and February 02, 1995 , were used to calculate water levels for 1994. Results of the calibrations and measured water-level altitudes obtained during the calibrations are as follows:

\begin{tabular}{ccccc}
\hline $\begin{array}{c}\text { Transducer serial } \\
\text { number }\end{array}$ & Calibration date & $\begin{array}{c}\text { Slope } \\
\text { (meters/millivolt) }\end{array}$ & $\begin{array}{c}\text { Coefficient of } \\
\text { determination }\end{array}$ & $\begin{array}{c}\text { Water-level } \\
\text { alitidu } \\
\text { (moters) }\end{array}$ \\
\hline 567098 & $12-28-93$ & 0.088 & 1.00 & 730.46 \\
567098 & $04-26-94$ & .088 & 1.00 & 730.57 \\
567098 & $07-26-94$ & .088 & 1.00 & 730.42 \\
567098 & $11-15-94$ & .089 & 1.00 & 730.44 \\
567098 & $02-15-95$ & .089 & 1.00 & 730.53 \\
\hline
\end{tabular}

${ }^{1}$ Well USW H-4, lower interval: The water-level measurement made on July 26,1994 , was made with Chain \#3. All other water-level measurements were made by tagging the water-surface with the transducer that was being calibrated.

Spikes were removed from the data on December $11,12,13$, and 14, 1994. The site was visited on December 13 and 14 and work conducted during these visits could be the cause of the spikes on these two days; however, for the remaining days the cause of the spikes is not known. All other transducer data collected for 1994 were considered to be valid. 
Water-level altitudes for well USW H-4, lower interval ranged from 730.38 to $730.61 \mathrm{~m}$ above sea level in 1994 (fig. 29). Mean monthly water-level altitudes are listed in table 20. The mean annual waterlevel altitude for 1994 was $730.49 \mathrm{~m}$ above sea level. This mean altitude was $0.08 \mathrm{~m}$ higher than the mean altitude of $730.41 \mathrm{~m}$ for 1993 (Tucci, Goemaat, and Burkhardt, 1996).

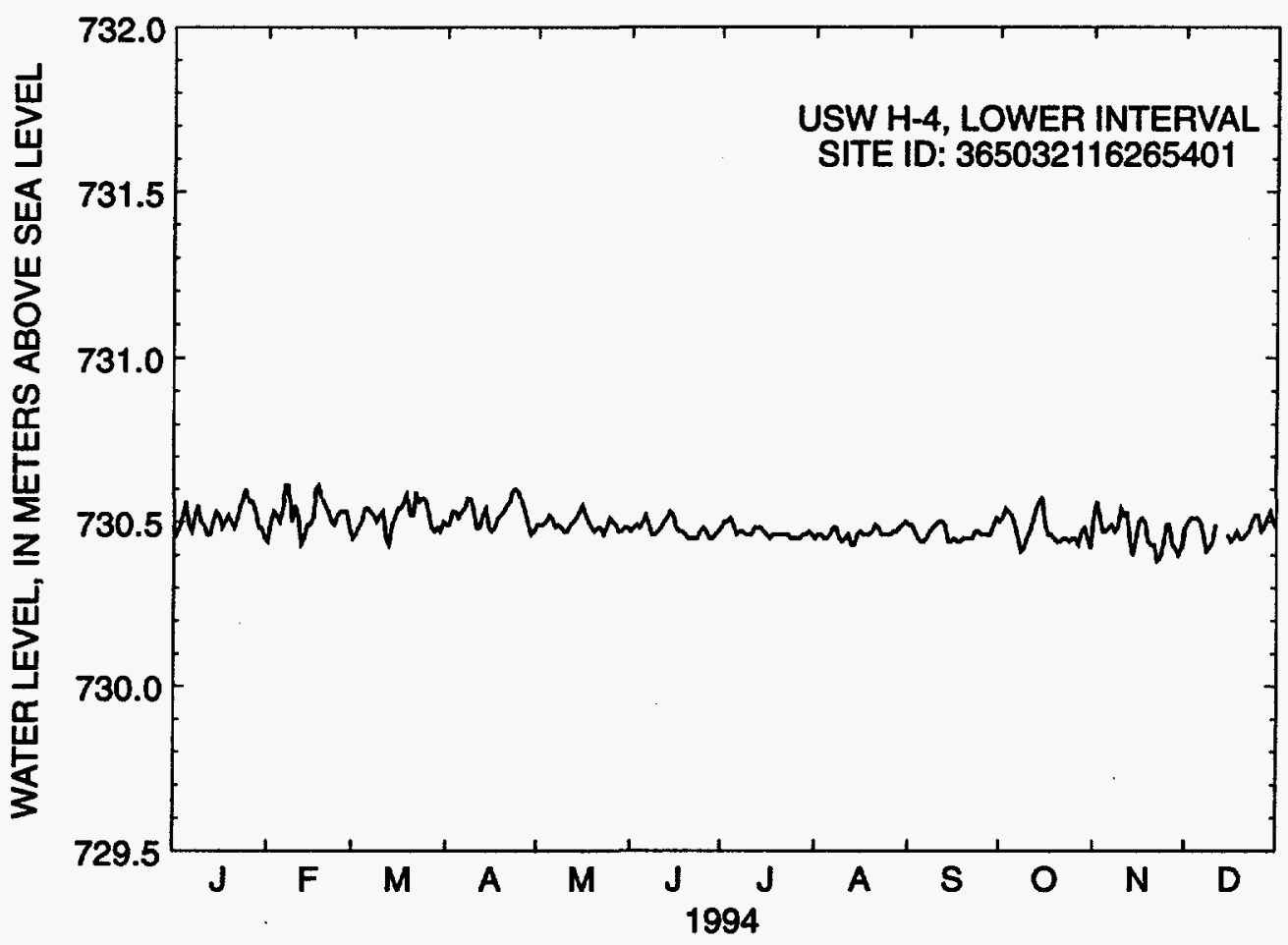

Flgure 29. Water-level altitudes, 1994, for well USW H-4, lower interval.

Table 20. Mean monthly water-level altitudes, 1994, for well USW H-4, lower interval

[Monthly means were calculated regardless of the number of days of missing data. Daily means were not calculated if 6 or more consecutive hours of data were missing]

\begin{tabular}{lcc}
\hline Month & $\begin{array}{c}\text { Water-lovel alitude } \\
\text { (moters, above sea level) }\end{array}$ & $\begin{array}{c}\text { Number of missing } \\
\text { dally means }\end{array}$ \\
\hline January & $\mathbf{7 3 0 . 5 1}$ & 0 \\
February & 730.52 & 0 \\
March & 730.51 & 0 \\
April & 730.52 & 0 \\
May & 730.49 & 0 \\
June & 730.48 & 0 \\
July & 730.47 & 0 \\
August & 730.46 & 0 \\
September & 730.46 & 0 \\
October & 730.47 & 0 \\
November & 730.47 & 0 \\
December & 730.48 & 3 \\
\hline
\end{tabular}




\section{Well USW H-5}

Information about the history of well USW H-5 and about previous data from the well was obtained from various sources. These sources are: Bentley and others (1983); Robison (1984, 1986); Robison and others (1988); and Fenix \& Scisson, Inc. (1987a, 1987c).

\section{Well specifications}

1. Location and identification:

Latitude and longitude: $36^{\circ} 51^{\prime} 22^{\prime \prime} \mathrm{N}$.; $116^{\circ} 27^{\prime} 55^{\prime \prime} \mathrm{W}$.

Nevada State Central Zone Coordinates (m): N 233,670; E 170,355.

U.S. Geological Survey Site ID: 365122116275501.

2. Drilling and casing information:

Well started: May 19, 1982.

Well completed: August 1, 1982.

Drilling method: Rotary, using rock bits and air-foam circulating medium; cores obtained from selected intervals.

Bit diameter below water level: $375 \mathrm{~mm}$ to $792 \mathrm{~m} ; 222 \mathrm{~mm}$ from $792 \mathrm{~m}$ to $1,219 \mathrm{~m}$.

Casing extending below water level: $255 \mathrm{~mm}$ diameter to $788 \mathrm{~m}$, perforated below the water level.

Total drilled depth: $1,219 \mathrm{~m}$.

3. Access to and description of interval for measuring water levels:

\section{Upper interval:}

48-mm inside-diameter open-ended tubing, extending from land surface to a depth of $709 \mathrm{~m}$; upper saturated interval of the borehole is within the Bullfrog and Tram Tuffs of the Crater Flat Group, bedded tuff, and unnamed lava beneath the Tram Tuff (Carr, 1988, p. 37) (Sawyer and others, 1994, p. 1305);

\section{Lower interval:}

62-mm inside-diameter tubing that has a 3.6-m-long inflatable packer on bottom end, extending from land surface to $846 \mathrm{~m}$; lower interval is within the Tram Tuff of the Crater Flat Group, and within an unnamed lava unit below the Tram Tuff (Carr, 1988, p. 37) (Sawyer and others, 1994, p. 1305).

Note: The packer was reset at its present depth $(846 \mathrm{~m})$ on $3 / 25 / 93$, from its previous depth of 1,091 m (G.M. O'Brien, U.S. Geological Survey, written commun., 1993).

4. Information for calculating water-level altitude:

Reference point: Top of metal tag on well casing; altitude $1,478.94 \mathrm{~m}$ (surveyed by U.S. Geological Survey, 1984).

Measuring point: Top of access tubes, $0.329 \mathrm{~m}$, upper interval; $0.235 \mathrm{~m}$, lower interval.

Depth correction for borehole deviation from vertical: $0.079 \mathrm{~m}$, based on approximate depth to water of $703 \mathrm{~m}$ (1990 data). 
Well USW H-5, upper interval was measured hourly during 1994. Six calibrations of two transducers were performed during 1994. In addition, calibrations on November 10, 1993, and February 7, 1995, were used to calculate water levels for 1994. Results of the calibrations and measured water-level altitudes obtained during the calibration are as follows:

\begin{tabular}{ccccc}
\hline $\begin{array}{c}\text { Transducer serial } \\
\text { number }\end{array}$ & Callbration date & $\begin{array}{c}\text { Slope } \\
\text { (metera/millivolt) }\end{array}$ & $\begin{array}{c}\text { Coefficient of } \\
\text { determination }\end{array}$ & $\begin{array}{c}\text { Water-level } \\
\text { altitude } \\
\text { (meters) }\end{array}$ \\
\hline 506116 & $11-10-93$ & 0.090 & 1.00 & 775.59 \\
506116 & $01-10-94$ & .090 & 1.00 & 775.54 \\
506116 & $01-18-94$ & .089 & 1.00 & 775.44 \\
570799 & $01-18-94$ & .088 & 1.00 & 775.44 \\
570799 & $03-03-94$ & .088 & 1.00 & 775.45 \\
570799 & $07-05-94$ & .088 & 1.00 & 775.48 \\
570799 & $10-14-94$ & .088 & 1.00 & 775.59 \\
570799 & $02-07-95$ & .089 & 1.00 & 775.46 \\
\hline
\end{tabular}

\footnotetext{
${ }^{1}$ Well USW H-5, upper interval: The water-level measurements made on January 18, 1994, and February 7, 1995, were made with Chain \#3. All other water-level measurements were made by tagging the water-surface with the transducer that was being calibrated.
}

Data were removed from January 1 through 18,1994 , because of a faulty transducer. Data are missing from this well for February 22 and 23, 1994, because the transducer was removed from the well for water-quality sampling. Data are missing from October 25 through 27, 1994, because of problems with the DCP program. All other transducer data collected for 1994 were considered to be valid.

Water-level altitudes for well USW H-5, upper interval ranged from 775.36 to $775.61 \mathrm{~m}$ above sea level in 1994 (fig. 30). Mean monthly water-level altitudes are listed in table 21. The mean annual waterlevel altitude for 1994 was $775.48 \mathrm{~m}$ above sea level. This mean altitude was $0.11 \mathrm{~m}$ lower than the mean altitude of $775.59 \mathrm{~m}$ for 1993 (Tucci, Goemaat, and Burkhardt, 1996).

Well USW H-5, lower interval was measured hourly during 1994. Six calibrations of two transducers were performed during 1994. In addition, calibrations on December 14, 1993, and February 8, 1995 , were used to calculate water levels for 1994. Results of the calibrations and measured water-level altitudes during the calibrations are as follows:

\begin{tabular}{ccccc}
\hline $\begin{array}{c}\text { Transducer sorlal } \\
\text { number }\end{array}$ & Callbration date & $\begin{array}{c}\text { Slope } \\
\text { (meters/millivolt) }\end{array}$ & $\begin{array}{c}\text { Coefficient of } \\
\text { dotermination }\end{array}$ & $\begin{array}{c}\text { Water-level } \\
\text { altitude' } \\
\text { (moters) }\end{array}$ \\
\hline 567095 & $12-14-93$ & 0.089 & 1.00 & 775.80 \\
567095 & $01-20-94$ & .089 & 1.00 & 775.66 \\
567095 & $02-22-94$ & .089 & 1.00 & 775.70 \\
525611 & $02-23-94$ & .354 & 1.00 & 775.68 \\
525611 & $03-03-94$ & .354 & 1.00 & 775.62 \\
525611 & $07-05-94$ & .354 & 1.00 & 775.61 \\
525611 & $10-14-94$ & .356 & 1.00 & 775.79 \\
525611 & $02-08-95$ & .353 & 1.00 & 775.74 \\
\hline
\end{tabular}

'Well USW H-5, lower interval: The water-level measurements made on December 14, 1993, February 22 and 23, 1994, and February 8, 1995, were made with Chain \#3. All other water-level measurements were made by tagging the water-surface with the transducer that was being calibrated. 


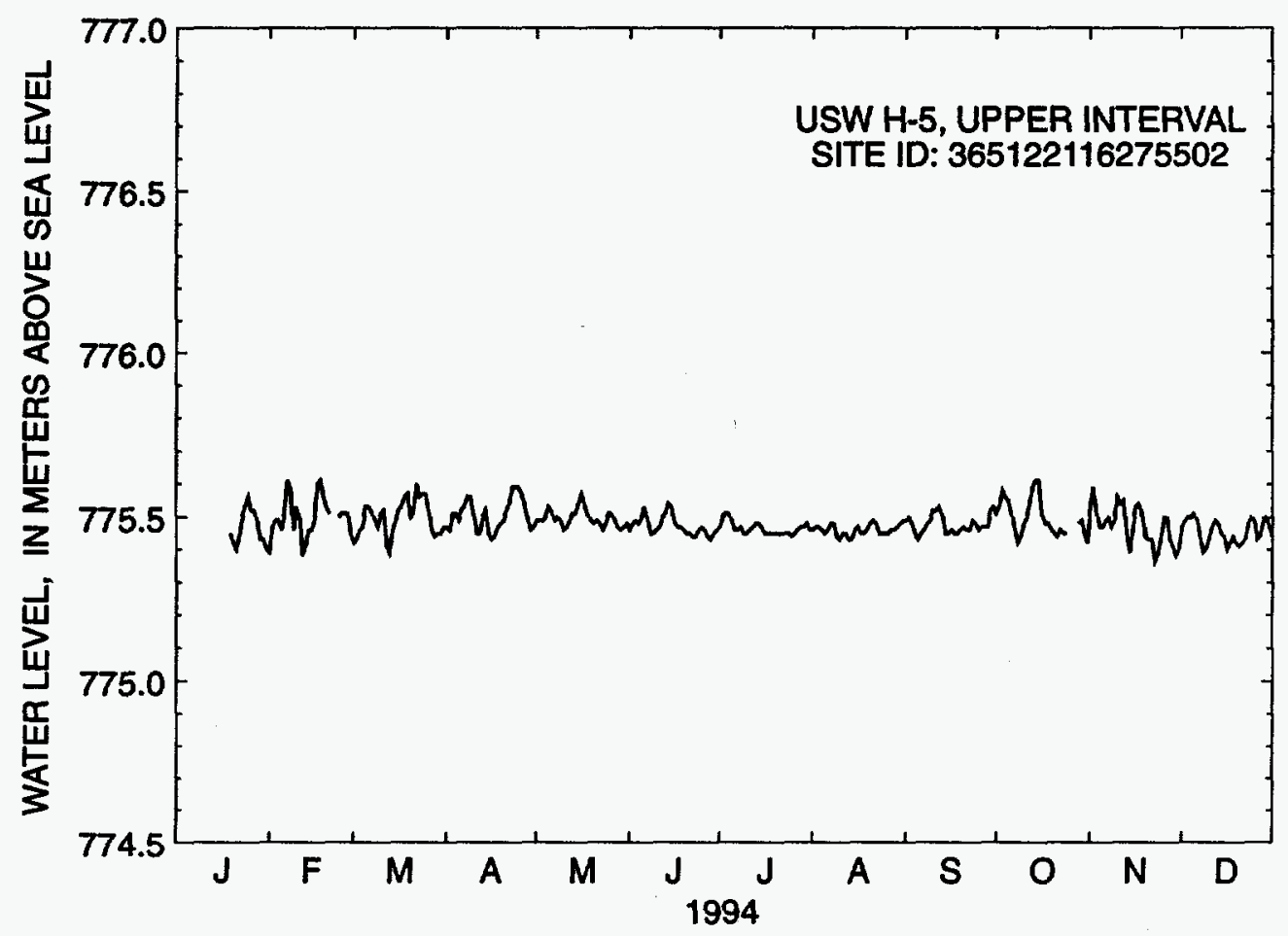

Figure 30. Water-level altitudes, 1994, for well USW H-5, upper interval.

Table 21. Mean monthly water-level altitudes, 1994, for well USW H-5, upper interval

[Monthly means were calculated regardless of the number of days of missing data. Daily means were not calculated if 6 or more consecutive hours of data were missing]

\begin{tabular}{lcc}
\hline Month & $\begin{array}{c}\text { Water-level altitude } \\
\text { (meters, above } \\
\text { sea level) }\end{array}$ & $\begin{array}{c}\text { Number of missing } \\
\text { daily means }\end{array}$ \\
\hline January & 775.47 & 18 \\
February & 775.50 & 2 \\
March & 775.50 & 0 \\
April & 775.51 & 0 \\
May & 775.50 & 0 \\
June & 775.47 & 0 \\
July & 775.46 & 0 \\
August & 775.46 & 0 \\
September & 775.48 & 0 \\
October & 775.50 & 3 \\
November & 775.47 & 0 \\
December & 775.46 & 0 \\
\hline
\end{tabular}


Data are missing from this well for February 22 and 23, 1994, because the transducer was removed for water-quality sampling. The transducer was also replaced on February 23. Data were removed from February 23, 1994, until March 3, 1994. There was a problem with the new transducer put in the well on February 23, 1994. The site was revisited on March 3, 1994, and the transducer was recalibrated. Data were removed for this well from August 15, 1994, through December 31, 1994. Transducer values were drifting severely during this timeframe and a correction factor to bring the data in line could not be applied. All other transducer data collected for 1994 were considered to be valid.

Water-level altitudes for well USW H-5, lower interval ranged from 775.54 to $775.83 \mathrm{~m}$ above sea level in 1994 (fig. 31). Mean monthly water-level altitudes are listed in table 22. The mean annual waterlevel altitude for 1994, was $775.65 \mathrm{~m}$ above sea level. This mean altitude was $0.07 \mathrm{~m}$ lower than the mean altitude of $775.72 \mathrm{~m}$ for 1993 (Tucci, Goemaat, and Burkhardt, 1996). 


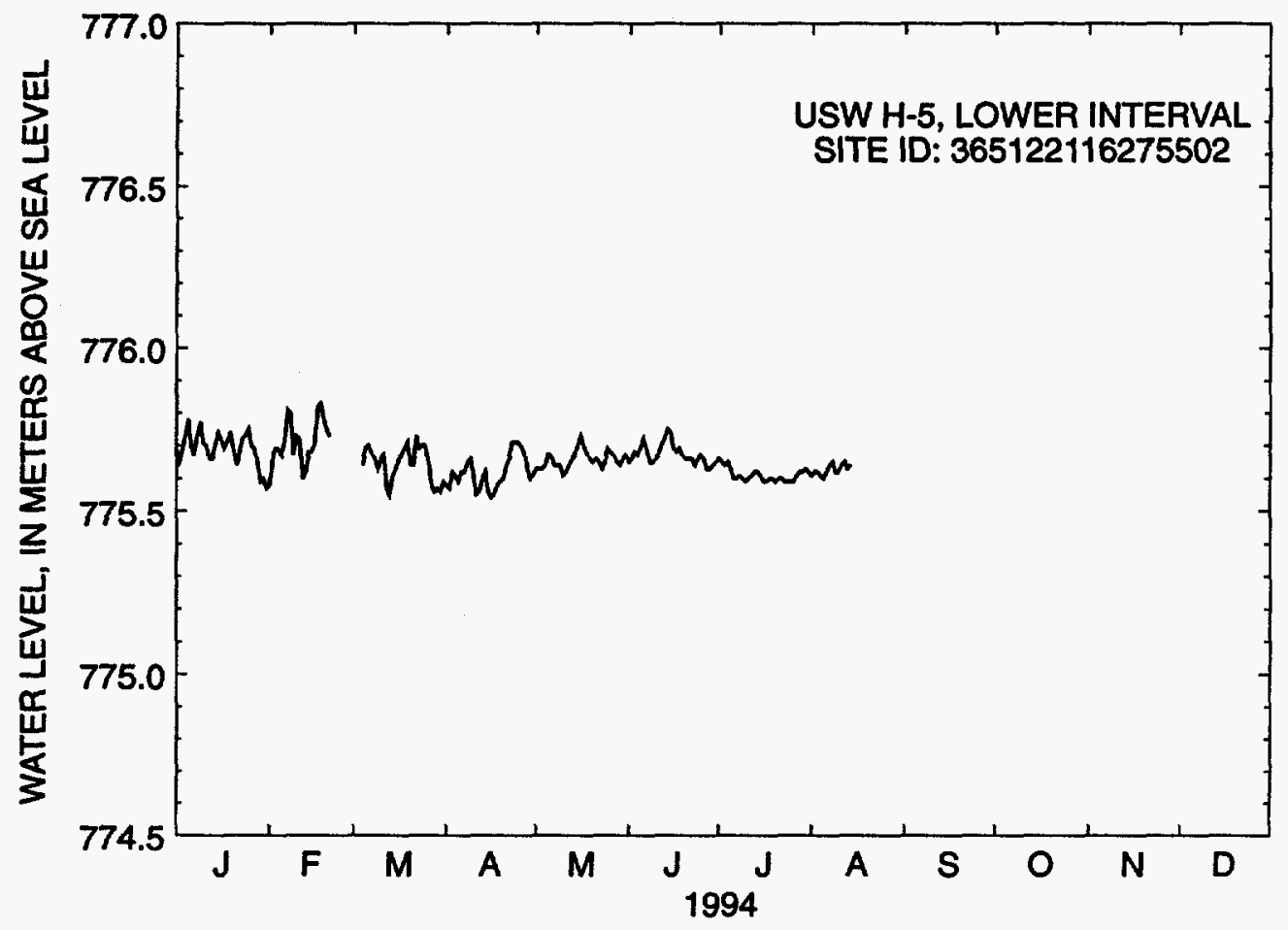

Figure 31. Water-level altitudes, 1994, for well USW H-5, lower interval.

Table 22. Mean monthly water-level altitudes, 1994, for well USW H-5, lower interval

[Monthly means were calculated regardless of the number of days of missing data. Daily means were not calculated if 6 or more consecutive hours of data were missing; --, data not available]

\begin{tabular}{lcc}
\hline Month & $\begin{array}{c}\text { Water-level altitude } \\
\text { (meters, above } \\
\text { sea level) }\end{array}$ & $\begin{array}{c}\text { Number of missing } \\
\text { daily means }\end{array}$ \\
\hline January & 775.69 & 0 \\
February & 775.71 & 7 \\
March & 775.64 & 3 \\
April & 775.62 & 0 \\
May & 775.66 & 0 \\
June & 775.67 & 0 \\
July & 775.61 & 0 \\
August & 775.63 & 17 \\
September & -- & 30 \\
October & -- & 31 \\
November & -- & 30 \\
December & -- & 31 \\
\hline
\end{tabular}




\section{Well USW H-6}

Information about the history of well USW H-6 and about previous data from the well was obtained from various sources. These sources are: Craig and others (1983); Robison (1984, 1986); Robison and others (1988); and Fenix \& Scisson, Inc. (1987a, 1987c).

Well specifications

1. Location and identification:

Latitude and longitude: $36^{\circ} 50^{\prime} 49^{\prime \prime} \mathrm{N}$.; $116^{\circ} 28^{\prime} 55^{\prime \prime} \mathrm{W}$.

Nevada State Central Zone Coordinates (m): N 232,654; E 168,882.

U.S. Geological Survey Site ID: 365049116285501.

2. Drilling and casing information:

Well started: August 7, 1982.

Well completed: October 28, 1982.

Drilling method: Rotary, using rock bits and air-foam circulating medium; cores obtained from selected intervals.

Bit diameter below water level: $375 \mathrm{~mm}$ to $583 \mathrm{~m} ; 222 \mathrm{~mm}$ from 583 to $1,216 \mathrm{~m}$; $156 \mathrm{~mm}$ from $1,216 \mathrm{~m}$ to $1,220 \mathrm{~m}$.

Casing extending below water level: $250-\mathrm{mm}$ diameter to $581 \mathrm{~m}$, perforated below the water level.

Total drilled depth: $1,220 \mathrm{~m}$.

3. Access to and description of interval for measuring water levels:

Upper interval:

48-mm inside diameter open-ended tubing, extending from land surface to $533 \mathrm{~m}$; saturated upper interval is within the Prow Pass, Bullfrog, and Tram Tuffs of the Crater Flat Group, and bedded tuff;

\section{Lower interval:}

62-mm inside diameter tubing with inflatable packer on bottom end, extending from land surface to $752 \mathrm{~m}$; lower interval is within the Tram Tuff of the Crater Flat Group, bedded tuff, an unnamed lava between the Tram Tuff and Lithic Ridge Tuff, (Carr, 1988 p. 37) (Sawyer and others, 1994, p. 1305) and the Lithic Ridge Tuff.

4. Information for calculating water-level altitude:

Reference point: Top of metal tag on well casing; altitude 1,302.06 m (surveyed by U.S. Geological Survey, 1984).

Measuring point: Top of access tubes, $0.207 \mathrm{~m}$, upper interval; $0.235 \mathrm{~m}$, lower interval.

Depth correction for borehole deviation from vertical: $0.052 \mathrm{~m}$, based on approximate depth to water of $526 \mathrm{~m}$ (1990 data).

Well USW H-6, upper interval, was measured hourly during 1994. Six calibrations of one transducer were performed during 1994. In addition, calibrations on October 25, 1993, and February 1, 1995 , were used to calculate water levels for 1994. Results of calibrations and measured water-level altitudes obtained during the calibrations are as follows: 


\begin{tabular}{ccccc}
\hline $\begin{array}{c}\text { Transducer serial } \\
\text { number }\end{array}$ & Calibration date & $\begin{array}{c}\text { Slope } \\
\text { (metera/millivolt) }\end{array}$ & $\begin{array}{c}\text { Coefficient of } \\
\text { determination }\end{array}$ & $\begin{array}{c}\text { Water-level } \\
\text { altitude } \\
\text { (moters) }\end{array}$ \\
\hline 255365 & $10-25-93$ & 0.088 & 1.00 & 776.05 \\
255365 & $02-11-94$ & .088 & 1.00 & 776.07 \\
255365 & $04-08-94$ & .089 & 1.00 & 776.13 \\
255365 & $05-06-94$ & .063 & 0.99 & 776.10 \\
567094 & $05-06-94$ & .088 & 1.00 & 776.10 \\
567094 & $06-29-94$ & .088 & 1.00 & 776.08 \\
567094 & $10-04-94$ & .089 & 1.00 & 776.16 \\
567094 & $02-01-95$ & .089 & 1.00 & 776.10 \\
\hline 'Well USW H-6, upper interval: The water-level measurement made on May 6, 1994, was made with \\
Chain \#3. All other water-level measurements were made by tagging the water-surface with the transducer that \\
was being calibrated.
\end{tabular}

All data were removed from 1200 on April 25, 1994, until 1400 on May 6, 1994. The poor data were due to a defective transducer, which was removed and replaced on May 6, 1994. Only partial data were collected for this well on November 16 and 17, 1994. The reason for the missing data is not known. A daily mean was not calculated for June 29,1994 , because the calibration of the well on this date took longer than 6 hours. All other data collected for 1994 were considered to be valid.

Water-level altitudes for well USW H-6 upper interval ranged from 775.95 to $776.26 \mathrm{~m}$ above sea level in 1994 (fig. 32). Mean monthly water-level altitudes are listed in table 23 . The mean annual waterlevel altitude for 1994 was $776.11 \mathrm{~m}$ above sea level. This mean altitude was $0.04 \mathrm{~m}$ higher than the mean altitude of $776.07 \mathrm{~m}$ for 1993 (Tucci, Goemaat, and Burkhardt, 1996).

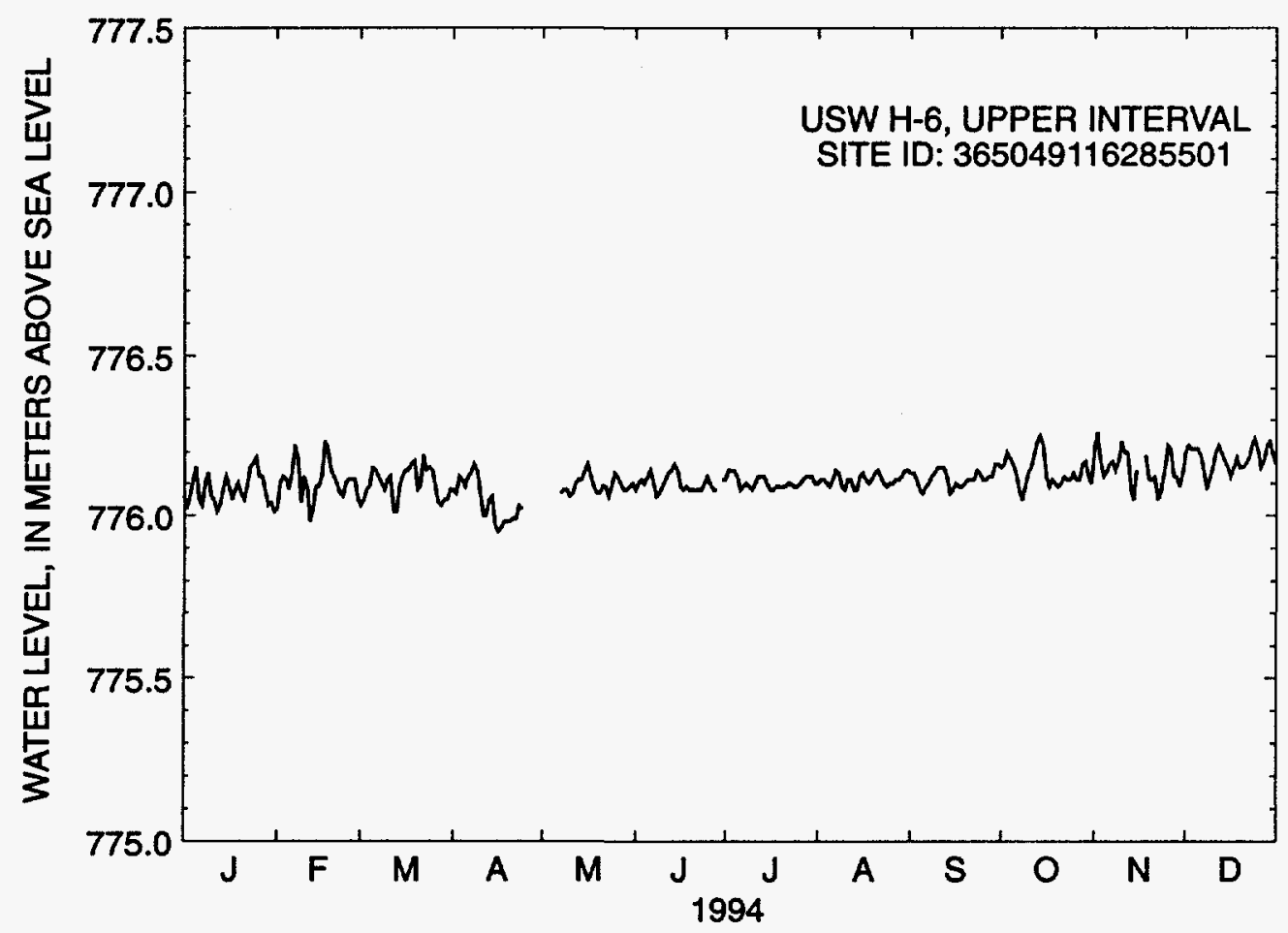

Figure 32. Water-level altitudes, 1994, for well USW H-6, upper interval. 
Table 23. Mean monthly water-level altitudes, 1994, for well USW H-6, upper level

[Monthly means were calculated regardless of the number of days of missing data. Daily means were not calculated if 6 or more consecutive hours of data were missing]

\begin{tabular}{lcc}
\hline Month & $\begin{array}{c}\text { Water-level altitude } \\
\text { (meters, above } \\
\text { sea level) }\end{array}$ & $\begin{array}{c}\text { Number of missing } \\
\text { daily means }\end{array}$ \\
\hline January & 776.08 & 0 \\
February & 776.10 & 0 \\
March & 776.10 & 0 \\
April & 776.04 & 6 \\
May & 776.09 & 6 \\
June & 776.10 & 1 \\
July & 776.10 & 0 \\
August & 776.11 & 0 \\
September & 776.11 & 0 \\
October & 776.14 & 0 \\
November & 776.15 & 2 \\
December & 776.18 & 0 \\
\hline
\end{tabular}

Well USW H-6, lower interval, was measured hourly during 1994. Six calibrations of three transducers were performed during 1994. In addition, calibrations on December 21, 1993, and February 1, 1995, were used to calculate water levels for 1994. Results of the calibrations and measured water-level altitudes obtained during the calibrations are as follows:

\begin{tabular}{ccccc}
\hline $\begin{array}{c}\text { Transducer serial } \\
\text { number }\end{array}$ & Calibration date & $\begin{array}{c}\text { Slope } \\
\text { (meters/millivolt) }\end{array}$ & $\begin{array}{c}\text { Coefficient of } \\
\text { determination }\end{array}$ & $\begin{array}{c}\text { Water-level } \\
\text { altitude } \\
\text { (meters) }\end{array}$ \\
\hline 525612 & $12-21-93$ & 0.356 & 1.00 & 776.00 \\
525612 & $04-08-94$ & .358 & 1.00 & 776.05 \\
525612 & $06-28-94$ & .354 & 1.00 & 775.94 \\
631043 & $06-29-94$ & .355 & 1.00 & 775.95 \\
631043 & $10-04-94$ & .354 & 1.00 & 776.07 \\
631043 & $11-16-94$ & .492 & 1.00 & 776.10 \\
626830 & $11-17-94$ & .354 & 1.00 & 776.04 \\
626830 & $02-01-95$ & .353 & 1.00 & 776.04 \\
\hline
\end{tabular}

${ }^{1}$ Well USW H-6, lower interval: The water-level measurements made on December 21, 1993, and June 29 and November 16 and 17, 1994, were made with Chain \#3. All other water-level measurements were made by tagging the water-surface with the transducer that was being calibrated.

All data from April 8, 1994, until June 28, 1994, were removed. The transducer was not functioning correctly during this timeframe. A daily mean was not calculated for June 28 and 29,1994 , because the calibration of the well on these dates took longer than 6 hours. All data from October 9, 1994, until November 17, 1994, were removed because the transducer was not working correctly. Even though the transducer was replaced on November 17, 1994, a daily mean was not calculated because the calibration took longer than 6 hours. Spikes were removed from the data on August 4 and September 12, 1994. The reason for the spikes is not known. All other transducer data collected for 1994 were considered to be valid. 
Water-level altitudes for well USW H-6, lower interval, ranged from 775.85 to $776.15 \mathrm{~m}$ above sea level in 1994 (fig. 33). Mean monthly water-level altitudes are listed in table 24. The mean annual waterlevel altitude for 1994 was $775.99 \mathrm{~m}$ above sea level. This mean altitude was $0.02 \mathrm{~m}$ higher than the mean altitude of $775.97 \mathrm{~m}$ for 1993 (Tucci, Goemaat, and Burkhardt, 1996).

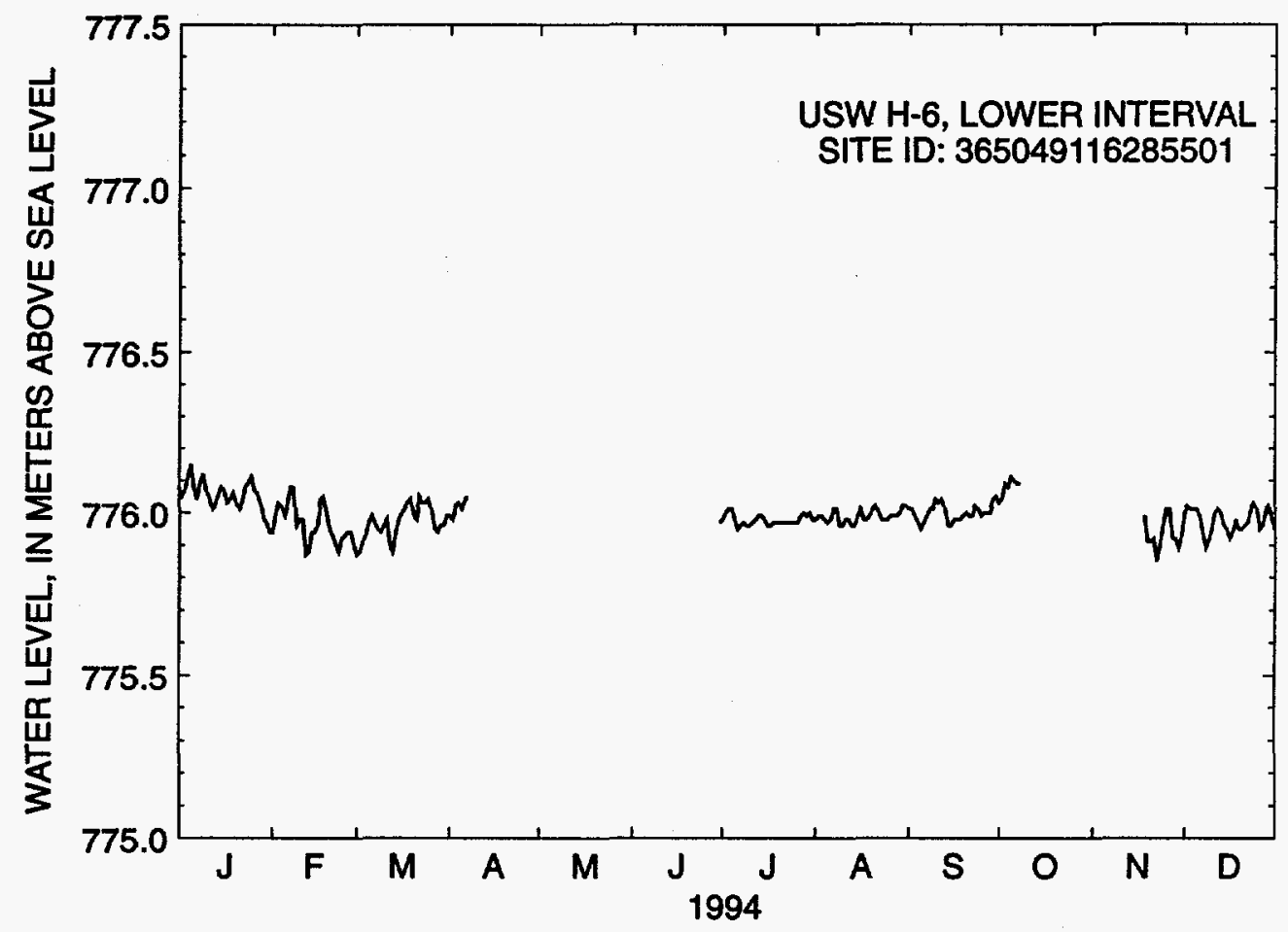

Figure 33. Water-level altitudes, 1994, for well USW H-6, lower interval.

Table 24. Mean monthly water-level altitudes, 1994, for well USW H-6, lower interval

[Monthly means were calculated regardless of the number of days of missing data. Daily means were not calculated if 6 or more consecutive hours of data were missing; ---, data not available]

\begin{tabular}{lcc}
\hline Month & $\begin{array}{c}\text { Water-level altitude } \\
\text { (meters, above sea level) }\end{array}$ & $\begin{array}{c}\text { Number of missing } \\
\text { dally means }\end{array}$ \\
\hline January & 776.05 & 0 \\
February & 775.97 & 0 \\
March & 775.97 & 0 \\
April & 776.02 & 23 \\
May & - & 31 \\
June & 775.97 & 29 \\
July & 775.98 & 0 \\
August & 775.99 & 0 \\
September & 776.00 & 0 \\
October & 776.08 & 23 \\
November & 775.93 & 17 \\
December & 775.98 & 0 \\
\hline
\end{tabular}




\section{Well USW VH-1}

Information about the history of well USW VH-1 and about previous data from the well was obtained from various sources. These sources are: Robison (1984, 1986); Robison and others (1988); Holmes \& Narver, Inc. (written commun., 1986); Fenix \& Scisson, Inc. (1986b, 1987c); and Thordarson and Howells (1987).

\section{Well specifications}

1. Location and identification:

Latitude and longitude: $36^{\circ} 47^{\prime} 32 \mathrm{~N}$.; $116^{\circ} 33^{\prime} 07^{\prime \prime} \mathrm{W}$.

Nevada State Central Zone Coordinates (m): N 226,575; E 162,649.

U.S. Geological Survey Site ID: 364732116330701.

2. Drilling and casing information:

Well started: October 28, 1980.

Well completed: February 18, 1981.

Drilling method: Rotary, using rock bits, and air-foam and polymer circulating medium.

Bit diameter below water level: $222 \mathrm{~mm}$ to $278 \mathrm{~m} ; 159 \mathrm{~mm}$ from $278 \mathrm{~m}$ to total depth.

Casing extending below water level: $177-\mathrm{mm}$ inside diameter to $278 \mathrm{~m}$.

Total drilled depth: $762 \mathrm{~m}$.

3. Access to and description of interval for measuring water levels:

48-mm inside-diameter tubing, open ended from land surface to $205.4 \mathrm{~m}$; saturated interval of the well is within the Tiva Canyon and Topopah Spring Tuffs of the Paintbrush Group, and the Prow Pass and Bullfrog Tuffs of the Crater Flat Group. A pump was installed in the well on July 8, 1982, at a depth of $212.8 \mathrm{~m}$.

4. Information for calculating water-level altitude:

Reference point: Top of metal tag on well casing, altitude $963.23 \mathrm{~m}$ (surveyed by

Holmes \& Narver, Inc., March 3, 1986).

Measuring point: Top of access tube, $0.631 \mathrm{~m}$.

Depth correction for borehole deviation from vertical: $0.049 \mathrm{~m}$, based on approximate depth to water of $184 \mathrm{~m}$ (1990 data).

5. Although drilled for the collection of hydrologic and geologic data from the underlying volcanic rocks, well USW VH-1 was pumped for water supply during 1994; the amount of water pumped in 1994 was 775 m $^{3}$ (R.A. LaCamera, U.S. Geological Survey, written commun., 1996).

Well USW VH-1 was measured periodically during 1994. Measurements were made with Chain \#3 and with the 2,800 foot reference steel tape with the following results: 


\begin{tabular}{ccc}
\hline Date & $\begin{array}{c}\text { Measured water-tevel altitude } \\
\text { (meters, above sea level) }\end{array}$ & Method \\
\hline $02-01-94$ & 779.43 & Chain \#3 \\
$02-25-94$ & 779.47 & Chain \#3 \\
$03-29-94$ & 779.46 & Chain \#3 \\
$04-22-94$ & 779.47 & Chain \#3 \\
$05-05-94$ & 779.49 & Chain \#3 \\
$06-08-94$ & 779.42 & Chain \#3 \\
$07-29-94$ & 779.47 & Chain \#3 \\
$08-25-94$ & 779.47 & Chain \#3 \\
$09-22-94$ & 779.48 & Chain \#3 \\
$10-26-94$ & 779.48 & Chain \#3 \\
$11-22-94$ & 779.41 & Chain \#3 \\
$12-09-94$ & 779.44 & 2,800 foot reference steel tape \\
\hline
\end{tabular}

Water-level altitudes for well USW VH-1 ranged from 779.41 to $779.49 \mathrm{~m}$ above sea level in 1994 (fig. 34). The mean annual water-level altitude of 1994 was $779.46 \mathrm{~m}$ above sea level. This mean altitude was the same as the mean altitude of $779.46 \mathrm{~m}$ for 1993 (Tucci, Goemaat, and Burkhardt, 1996).

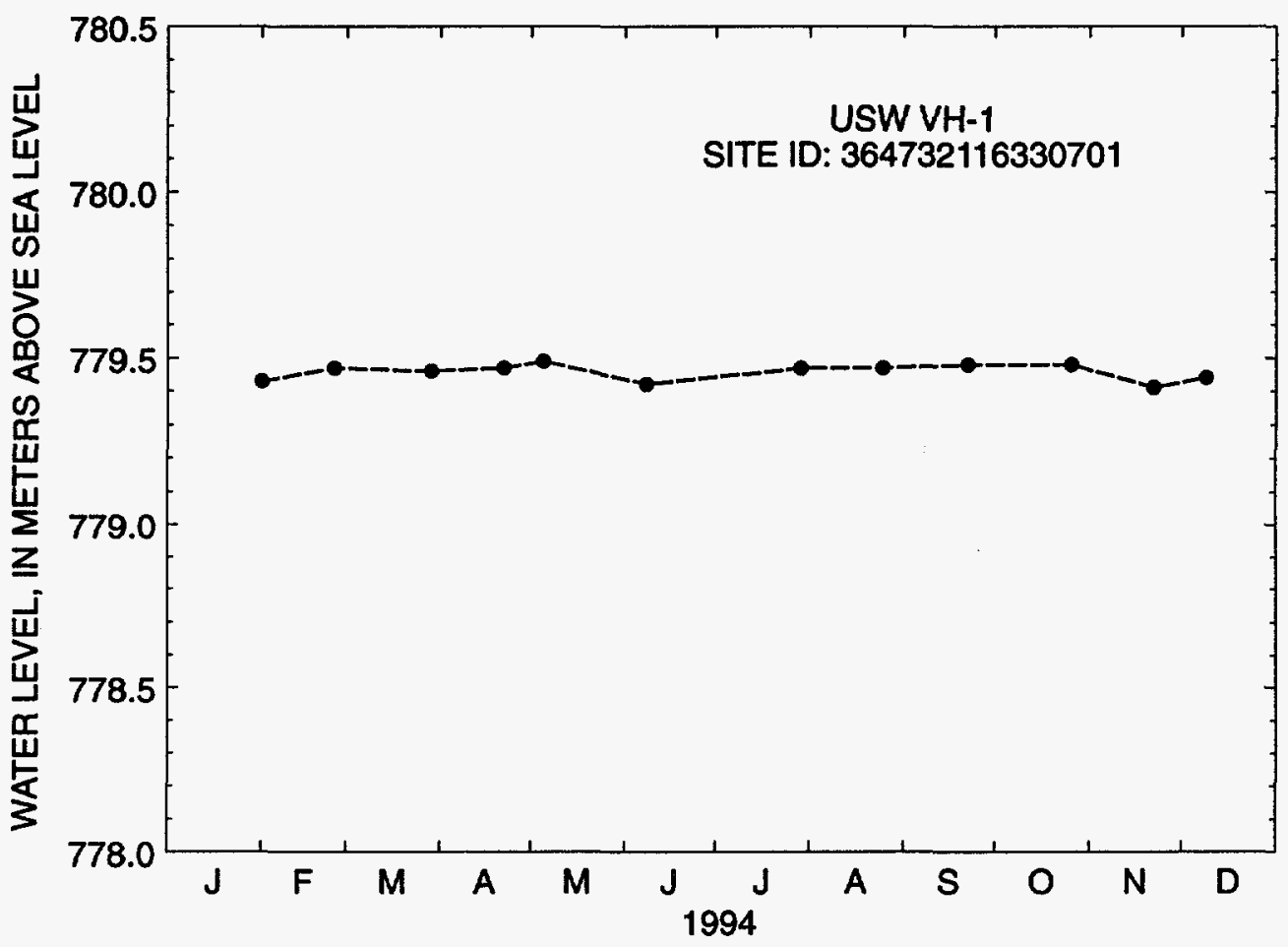

Figure 34. Water-level altitudes, 1994, for well USW VH-1. 


\section{Well J-11}

Information about the history of well USW J-11 and about previous data from the well was obtained from Young (1972), and Fenix \& Scisson, Inc. (1987c).

\section{Well specifications}

1. Location and identification:

Latitude and longitude: $36^{\circ} 47^{\prime} 06^{\prime \prime} \mathrm{N} . ; 116^{\circ} 17^{\prime} 06^{\prime \prime} \mathrm{W}$.

Nevada State Central Zone Coordinates (m): N 740,968; E 611,764.

U.S. Geological Survey Site ID: 364706116170601.

2. Drilling and casing information:

Well started: June 4, 1957.

Well completed: July 19, 1957.

Drilling method: Cable-tool.

Bit diameter below water level: $400 \mathrm{~mm}$.

Casing extending below water level: 308 -mm inside-diameter casing extends from land surface to $404.5 \mathrm{~m}$.

Total drilled depth: $405 \mathrm{~m}$.

3. Access to and description of interval for measuring water levels:

308-mm inside-diameter casing; the casing is perforated from 328.3 to $334.4 \mathrm{~m}$ and from 379.2 to $396.2 \mathrm{~m}$. The well produces water from the basalt of Kiwi Mesa and from the welded-tuff aquifer, located within the Topopah Spring Tuff of the Paintbrush Group.

4. Information for calculating water-level altitude:

Reference point: Chiseled " $X$ " in concrete pad near well; altitude $1,049.45 \mathrm{~m}$ (surveyed by U.S. Geological Survey, 1993).

Measuring point: Top of casing, even with top of concrete block, $0.555 \mathrm{~m}$.

Depth correction for borehole deviation from vertical is not available.

Well J-11 was measured periodically during 1994. Measurements were made with Chain \#3 and the 2,800 foot reference steel tape with the following results:

\begin{tabular}{ccc}
\hline Date & $\begin{array}{c}\text { Measured water-level aitltude } \\
\text { (moters, above sea level) }\end{array}$ & Method \\
\hline $02-03-94$ & 732.24 & Chain \#3 \\
$03-01-94$ & 732.13 & Chain \#3 \\
$03-15-94$ & 732.23 & Chain \#3 \\
$05-02-94$ & 732.21 & Chain \#3 \\
$05-27-94$ & 732.23 & Chain \#3 \\
$06-24-94$ & 732.21 & Chain \#3 \\
$07-27-94$ & 732.24 & Chain \#3 \\
$09-06-94$ & 732.19 & Chain \#3 \\
$09-30-94$ & 732.28 & Chain \#3 \\
$10-27-94$ & 732.17 & Chain \#3 \\
$12-02-94$ & 732.28 & Chain \#3 \\
$12-08-94$ & 732.14 & 2,800 foot reference steel tape \\
\hline
\end{tabular}


Water level altitudes for well J-11 ranged from 732.13 to $732.28 \mathrm{~m}$ above sea level in 1994 (fig. 35 ). The mean annual water-level altitude for 1994 was $732.21 \mathrm{~m}$ above sea level. This mean altitude was the same as the mean altitude of $732.21 \mathrm{~m}$ for 1993 (Tucci, Goemaat, and Burkhardt, 1996).

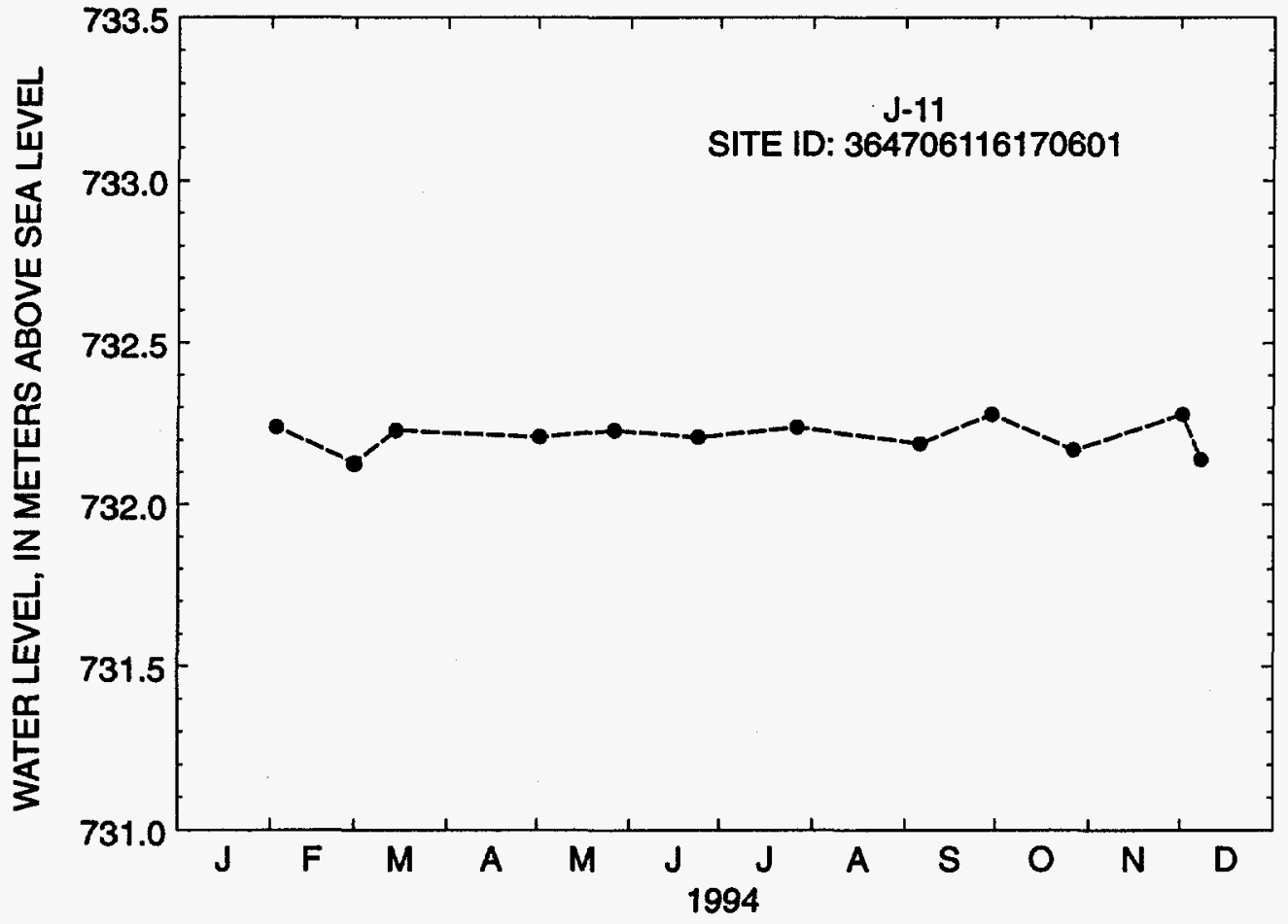

Figure 35. Water-level altitudes, 1994, for well J-11. 
Information about the history of well USW J-12 and about previous data from the well was obtained from Young (1972), and Fenix \& Scisson, Inc. (1987c).

Well specifications

1. Location and identification:

Latitude and longitude: $36^{\circ} 45^{\prime} 54^{\prime \prime} \mathrm{N}$.; $116^{\circ} 23^{\prime} 24^{\prime \prime} \mathrm{W}$.

Nevada State Central Zone Coordinates (m): N 733,508; E 581,012.

U.S. Geological Survey Site ID: 364554116232401.

2. Drilling and casing information:

Well started: August 4, 1957.

Well completed: October 9, 1957; well was deepened in August 1968.

Drilling method: Cable-tool (1957); unknown 1968.

Bit diameter below water level: $400-\mathrm{mm}$ to $271 \mathrm{~m}, 298-\mathrm{mm}$ to $347 \mathrm{~m}$.

Casing extending below water level: 308 -mm inside-diameter casing extending from land surface to $271 \mathrm{~m}$.

Total drilled depth: $271 \mathrm{~m}$ (1957); $347 \mathrm{~m}$ after the deepening in 1968.

3. Access to and description of interval for measuring water levels:

308 -mm inside-diameter casing; the casing is perforated between $241-264 \mathrm{~m}$; the hole is open from $271 \mathrm{~m}$ to $347 \mathrm{~m}$; access tube is 54-mm outside-diameter. The well produces water from the weldedtuff aquifer, located within the Topopah Spring Tuff of the Paintbrush Group.

4. Information for calculating water-level altitude:

Reference point: Top of well collar, altitude $954.54 \mathrm{~m}$ (surveyed by U.S. Geological Survey, 1993).

Measuring point: Top of the 54-mm outside-diameter access tube, $0.527 \mathrm{~m}$.

Depth correction for borehole deviation from vertical is not available.

5. The amount of water pumped from well J-12 in 1994 was approximately $181,483 \mathrm{~m}^{3}$ (Clary and others, 1995; and R.A. LaCamera, U.S. Geological Survey, written commun., 1995).

Well J-12 was measured periodically during 1994. All measurements were made with Chain \#3 with the following results: 


\begin{tabular}{ccc}
\hline Date & $\begin{array}{c}\text { Measured water-lovel altitude } \\
\text { (moters, above sou lovel) }\end{array}$ & Mothod \\
\hline $01-14-94$ & 727.99 & Chain \#3 \\
$02-02-94$ & 727.98 & Chain \#3 \\
$02-10-94$ & 727.94 & Chain \#3 \\
$03-01-94$ & 727.84 & Chain \#3 \\
$03-10-94$ & 727.95 & Chain \#3 \\
$03-24-94$ & 727.95 & Chain \#3 \\
$04-15-94$ & 727.86 & Chain \#3 \\
$04-29-94$ & 727.85 & Chain \#3 \\
$05-05-94$ & 727.96 & Chain \#3 \\
$05-16-94$ & 728.00 & Chain \#3 \\
$05-27-94$ & 727.92 & Chain \#3 \\
$06-10-94$ & 727.92 & Chain \#3 \\
$06-24-94$ & 727.92 & Chain \#3 \\
$07-08-94$ & 727.89 & Chain \#3 \\
$07-28-94$ & 727.89 & Chain \#3 \\
$08-05-94$ & 727.93 & Chain \#3 \\
$08-31-94$ & 727.89 & Chain \#3 \\
$09-16-94$ & 727.87 & Chain \#3 \\
$09-30-94$ & 727.92 & Chain \#3 \\
$10-11-94$ & 727.90 & Chain \#3 \\
$10-27-94$ & 727.84 & Chain \#3 \\
$11-29-94$ & 727.81 & Chain \#3 \\
$12-13-94$ & 727.92 & Chain \#3 \\
$12-29-94$ & 727.95 & Chain \#3 \\
\hline & &
\end{tabular}

Water-level altitudes for well J-12 ranged from 727.81 to $728.00 \mathrm{~m}$ above sea level in 1994 (fig. 36). The mean annual water-level altitude for 1994 was $727.91 \mathrm{~m}$ above sea level. This mean altitude was $0.06 \mathrm{~m}$ lower than the mean altitude of $727.97 \mathrm{~m}$ for 1993 (Tucci, Goemaat, and Burkhardt, 1996).

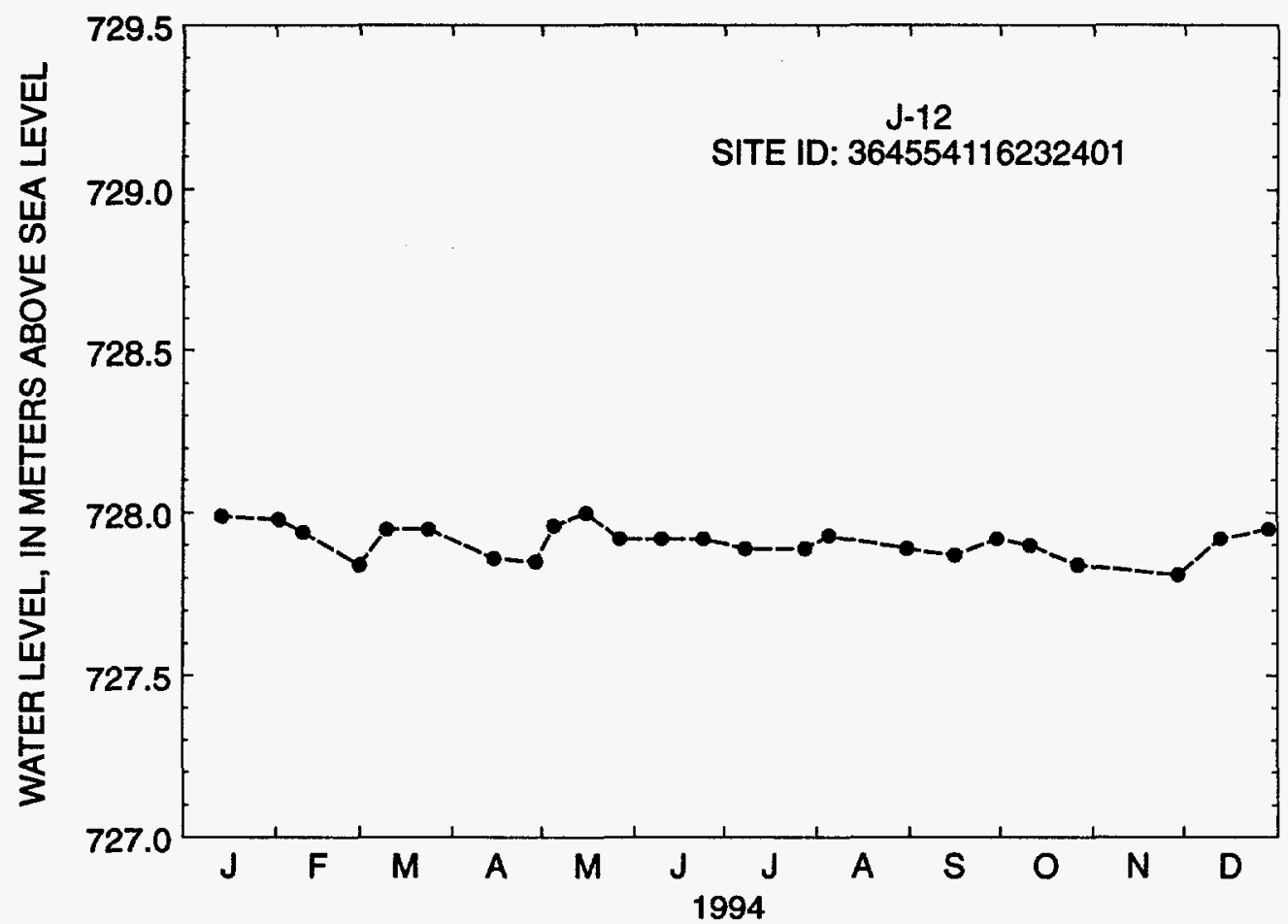

Figure 36. Water-level altitudes, 1994, for well J-12. 


\section{Well J-13}

Information about the history of well $\mathrm{J}-13$ and about previous data from the well was obtained from various sources. These sources are: Robison (1984, 1986); Robison and others (1988); Holmes \& Narver, Inc. (written commun., 1986); Thordarson (1983); Young (1972); and Fenix \& Scisson, Inc. $(1987 \mathrm{c})$.

\section{Well specifications}

1. Location and identification:

Latitude and longitude: $36^{\circ} 48^{\prime} 29^{\prime \prime} \mathrm{N}$.; $116^{\circ} 23^{\prime} 40^{\prime \prime} \mathrm{W}$.

Nevada State Central Zone Coordinates (m): N 228,359; E 176,678.

U.S. Geological Survey Site ID: 364828116234001.

2. Drilling and casing information:

Well started: September 12, 1962.

Well completed: January 8, 1963.

Drilling method: Rotary, using air and aerated mud as circulating medium.

Bit diameter below water level: $438 \mathrm{~mm}$ to $402 \mathrm{~m} ; 380 \mathrm{~mm}$ from $402 \mathrm{~m}$ to $471 \mathrm{~m}$; $194 \mathrm{~mm}$ from $471 \mathrm{~m}$ to total depth.

Casing extending below water level: $323-\mathrm{mm}$ inside diameter, from land surface to $396.5 \mathrm{~m} ; 282-\mathrm{mm}$ inside diameter from 396.5 to $471.2 \mathrm{~m} ; 126-\mathrm{mm}$ inside diameter from 452.3 to $1,031.7 \mathrm{~m}$; casing perforated from 303.6 to $423.7 \mathrm{~m}$ is within the Topopah Spring Tuff of the Paintbrush Group, and from 819.9 to $1,009.5 \mathrm{~m}$ is within the Tram

Tuff of the Crater Flat Group and upper part of the Lithic Ridge Tuff.

Total drilled depth: $1,063 \mathrm{~m}$.

3. Access to and description of interval for measuring water levels:

50.8-mm inside-diameter access tube, installed in 1986, in order for measuring equipment to bypass pump assembly.

4. Information for calculating water-level altitude:

Reference point: Chiseled square on concrete well collar, altitude $1,011.47 \mathrm{~m}$

(surveyed by U.S. Geological Survey, 1984).

Measuring point: Top of access tube, $0.165 \mathrm{~m}$.

Depth correction for borehole deviation from vertical is not available.

5. The amount of water pumped from well J-13 in 1994 was approximately $159,988 \mathrm{~m}^{3}$

(Clary, S.L. and others, 1995, and R.A. LaCamera, U.S. Geological Survey, written commun., 1995).

Well J-13 was measured periodically during 1994. All measurements were made with Chain \#3 with the following results: 


\begin{tabular}{|c|c|c|}
\hline Date & $\begin{array}{l}\text { Measured water-tovel attitude } \\
\text { (moters, above sea lovel) }\end{array}$ & Mothod \\
\hline $01-14-94$ & 728.41 & Chain \#3 \\
\hline $02-02-94$ & 728.44 & Chain \#3 \\
\hline 02-10-94 & 728.48 & Chain \#3 \\
\hline 03-01-94 & 728.35 & Chain \#3 \\
\hline $03-15-94$ & 728.46 & Chain \#3 \\
\hline $03-24-94$ & 728.42 & Chain \#3 \\
\hline 04-15-94 & 728.36 & Chain \#3 \\
\hline $04-29-94$ & 728.34 & Chain \#3 \\
\hline $05-18-94$ & 728.37 & Chain \#3 \\
\hline $05-27-94$ & 728.41 & Chain \#3 \\
\hline $06-10-94$ & 728.41 & Chain \#3 \\
\hline $06-24-94$ & 728.39 & Chain \#3 \\
\hline $07-08-94$ & 728.37 & Chain \#3 \\
\hline $07-27-94$ & 728.39 & Chain \#3 \\
\hline $08-05-94$ & 728.36 & Chain \#3 \\
\hline $08-31-94$ & 728.41 & Chain \#3 \\
\hline $09-16-94$ & 728.31 & Chain \#3 \\
\hline $09-30-94$ & 728.46 & Chain \#3 \\
\hline $10-12-94$ & 728.39 & Chain \#3 \\
\hline $10-27-94$ & 728.35 & Chain \#3 \\
\hline $11-10-94$ & 728.48 & Chain \#3 \\
\hline $11-29-94$ & 728.30 & Chain \#3 \\
\hline $12-13-94$ & 728.41 & Chain \#3 \\
\hline $12-29-94$ & 728.48 & Chain \#3 \\
\hline
\end{tabular}

Water-level altitudes for well J-13 ranged from 728.30 to $728.48 \mathrm{~m}$ above sea level in 1994 (fig. 37 ). The mean annual water-level altitude for 1994 was $728.40 \mathrm{~m}$ above sea level. This mean altitude was 0.07 lower than the mean altitude of $728.47 \mathrm{~m}$ for 1993 (Tucci, Goemaat, and Burkhardt, 1996).

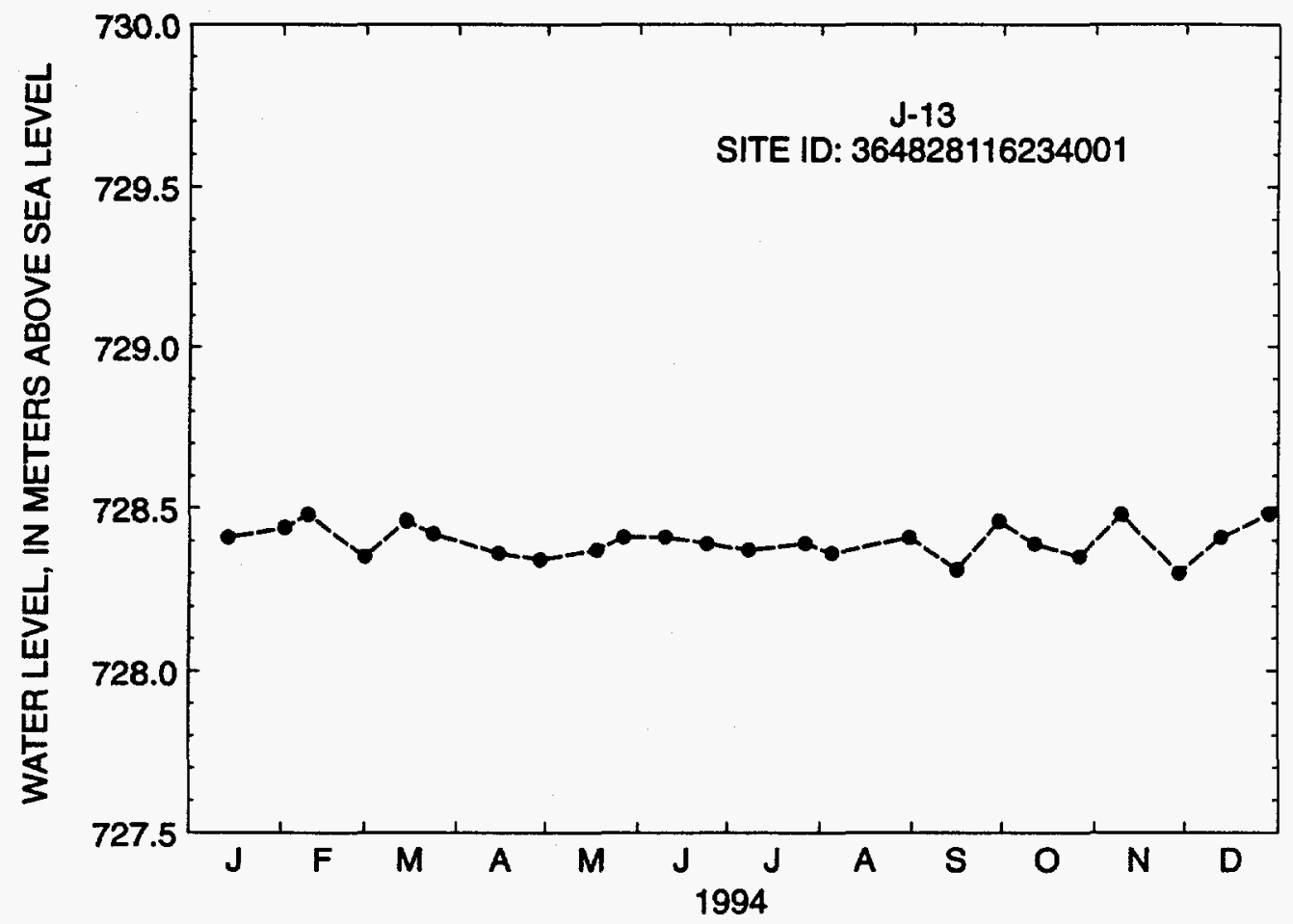

Figure 37. Water-level altitudes, 1994, for well J-13. 


\section{REFERENCES CITED}

Bentley, C.B., Robison, J.H., and Spengler, R.W., 1983, Geohydrologic data for test well USW H-5, Yucca Mountain area, Nye County, Nevada: U.S. Geological Survey Open-File Report 83-853, 34 p.

Blee, J.W.H., Herlong, H.E., Kauffman, C.D., Jr., Hardee, J.H., Field, M.L., and Middleburg, R.F., Jr., 1986, GOES datacollection system instrumentation, installation, and maintenance manual: U.S. Geological Survey Open-File Report 86-479, various pagination.

Boucher, M.S., 1994a, Precision and accuracy of manual water-level measurements taken in the Yucca Mountain area, Nye County, Nevada, 1988-90: U.S. Geological Survey Water-Resources Investigations Report 93-4025, 18 p.

Boucher, M.S., 1994b, Water levels in wells J-11 and J-12, 1989-91, Yucca Mountain area, Nevada: U.S. Geological Survey Open-File Report 94-303, 9 p.

Byers, F.M., Jr., Carr, W.J., Orkild, P.P., Quinlivan, W.D., and Sargent, K.A., 1976, Volcanic suites and related cauldrons of Timber Mountain-Oasis Valley caldera complex, southern Nevada: U.S. Geological Survey Professional Paper 919, $70 \mathrm{p}$.

Carr, W.J., Byers, F.M., Jr., and Orkild, P.P., 1986, Stratigraphic and volcano-tectonic relations of Crater Flat Tuff and some older volcanic units, Nye County, Nevada: U.S. Geological Survey Professional Paper 1323, 28 p.

Carr, W.J., 1988, Volcano-tectonic setting of Yucca Mountain and Crater Flat, southwestern Nevada, in Carr, M.D., and Yount, J.C. (eds.), Geologic and hydrologic investigations of a potential nuclear waste disposal site at Yucca Mountain, southern Nevada: U.S. Geological Survey Bulletin 1790, p. 35-49.

Clary, S.L., McClary, D.R., Whitney, Rita, and Reeves, D.R., 1995, Water Resources Data Nevada, Water Year 1994, U.S. Geological Survey Water-Data Report NV-94-1, 785 p.

Craig, R.W., and Johnson, K.A., 1984, Geohydrologic data for test well UE-25p \#1, Yucca Mountain area, Nye County, Nevada: U.S. Geological Survey Open-File Report 84-450, 63 p.

Craig, R.W., Reed, R.L., and Spengler, R.W., 1983, Geohydrologic data for test well USW H-6, Yucca Mountain area, Nye County, Nevada: U.S. Geological Survey Open-File Report 83-856, 35 p.

Craig, R.W., and Robison, J.H., 1984, Geohydrology of test well UE-25p \#1, Yucca Mountain area, Nye County, Nevada: U.S. Geological Survey Water-Resources Investigations Report 84-4248, 57 p.

Erickson, J.R., and Waddell, R.K., 1985, Identification and characterization of hydrologic properties of fractured tuff using hydraulic and tracer tests-test well USW H-4, Yucca Mountain, Nye County, Nevada: U.S. Geological Survey WaterResources Investigations Report 85-4066, 30 p.

Fenix \& Scisson, Inc., 1986a, NNWSI hole histories-UE-25 WT \#3, UE-25 WT \#4, UE-25 WT \#5, UE-25 WT \#6, UE-25 WT \#12, UE-25 WT \#13, UE-25 WT \#14, UE-25 WT \#15, UE-25 WT \#16, UE-25 WT \#17, UE-25 WT \#18, USW WT-1, USW WT-2, USW WT-7, USW WT-10, USW WT-11: U.S. Department of Energy DOE/NV/10322-10, $111 \mathrm{p}$.

1986b, NNWSI hole history-UE-25b \#1: U.S. Department of Energy DOE/NV/10322-13, 37 p.

1986c, NNWSI hole history-UE-25p \#1: U.S. Department of Energy DOE/NV/10322-16, 39 p.

1986d, NNWSI hole histories-UE-25c \#1, UE-25c \#2, UE-25c \#3: U.S. Department of Energy, DOE/NV/10322-14, $60 \mathrm{p}$.

1987a, NNWSI hole histories-USW H-1, USW H-3, USW H-4, USW H-5, USW H-6: U.S. Department of Energy DOE/NV/10322-18, $99 \mathrm{p}$.

1987b, NNWSI hole histories-USW G-1, USW G-2, USW G-3, USW G-4, USW GA-1, USW GU-3: U.S. Department of Energy DOE/NV/10322-19, $187 \mathrm{p}$.

1987c, NNWSI drilling and mining summary: U.S. Department of Energy DOE/NV/10322-24, 45 p.

Garber, M.S., and Koopman, F.C., 1968, Methods of measuring water levels in deep wells: U.S. Geological Survey Techniques of Water-Resources Investigations, book 8, chap. A-1, 23 p.

Gemmell, J.M., 1990, Water levels in periodically measured wells in the Yucca Mountain area, Nevada, 1988: U.S. Geological Survey Open-File Report 90-113, 47 p.

Lahoud, R.G., Lobmeyer, D.H., and Whitfield, M.S., Jr., 1984, Geohydrology of volcanic tuff penetrated by test well UE-25b \#1, Yucca Mountain, Nye County, Nevada: U.S. Geological Survey Water-Resources Investigations Report 84-4253, 44 p. 
Lobmeyer, D.H., Luckey, R.R., O'Brien, G.M., and Burkhardt, D.J., 1995, Water levels in continuously monitored wells in the Yucca Mountain area, Nevada, 1989: U.S. Geological Survey Open-File Report 93-098, 173 p.

Lobmeyer, D.H., Whitfield, M.S., Jr., Lahoud, R.G., and Bruckheimer, Laura, 1983, Geohydrologic data for test well UE-25b \#1, Nevada Test Site, Nye County, Nevada: U.S. Geological Survey Open-File Report 83-855, 48 p.

Luckey, R.R., Lobmeyer, D.H., and Burkhardt, Douglas, 1993, Water levels in continuously monitored wells in the Yucca Mountain area, Nevada, 1985-88: U.S. Geological Survey Open-File Report 91-493, 252 p.

Maldonado, Florian, and Koether, S.L., 1983, Stratigraphy, structure, and some petrographic features of Tertiary volcanic rocks at the USW G-2 Drill Hole, Yucca Mountain, Nye County, Nevada: U.S. Geological Survey Open-File Report 83-732, 83 p.

Muller, D.C., and Kibler, J.E., 1985, Preliminary analysis of geophysical logs from WT series drill holes, Yucca Mountain, Nye County, Nevada: U.S. Geological Survey Open-File Report 86-46, 29 p.

Nelson, P.H., Muller, D.C., Schimschal, Ulrich, and Kibler, J.E., 1991, Geophysical logs and core measurements from forty boreholes at Yucca Mountain, Nevada: U.S. Geological Survey Geophysical Investigations Map GP-1001, 64 p., 40 pls.

Nelson, P.H., and Schimschal, Ulrich, 1993, Assessment of geophysical logs from borehole USW G-2, Yucca Mountain, Nevada: U.S. Geological Survey Open-File Report 92-572, 34 p.

O'Brien, G.M., 1991, Water levels in periodically measured wells in the Yucca Mountain area, Nevada, 1989: U.S. Geological Survey Open-File Report 91-178, $51 \mathrm{p}$.

1992, Earthquake-induced water-level fluctuations at Yucca Mountain, Nevada, April, 1992: U.S. Geological Survey Open-File Report 92-137, $10 \mathrm{p}$.

1993, Earthquake-induced water-level fluctuations at Yucca Mountain, Nevada, June, 1992: U.S. Geological Survey Open-File Report 93-73, 12 p.

O'Brien, G.M., Tucci, Patrick, and Burkhardt, D.J., 1995, Water levels in the Yucca Mountain area, Nevada, 1992: U.S. Geological Survey Open-File Report 94-311, 74 p.

Robison, J.H., 1984, Ground-water level data and preliminary potentiometric surface maps, Yucca Mountain and vicinity, Nye County, Nevada: U.S. Geological Survey Water-Resources Investigations Report 84-4197, 8 p.

1986, Letter from J.H. Robison (U.S. Geological Survey, Lakewood, Colorado) to D.L. Vieth (U.S. Department of Energy-Nevada Operations Office, Las Vegas, Nevada), September 17, 1986; regarding revisions of Yucca Mountain water levels reported in Robison, 1984.

Robison, J.H., Stephens, D.M., Luckey, R.R., and Baldwin, D.A., 1988, Water levels in periodically measured wells in the Yucca Mountain area, Nevada, 1981-87: U.S. Geological Survey Open-File Report 88-468, 132 p.

Rush, F.E., Thordarson, William, and Bruckheimer, Laura, 1983, Geohydrologic and drill-hole data for test well USW H-1, adjacent to Nevada Test Site, Nye County, Nevada: U.S. Geological Survey Open-File Report 83-141, 38 p.

Rush, F.E., Thordarson, William, and Pyles, D.G., 1984, Geohydrology of test well USW H-1, Yucca Mountain, Nye County, Nevada: U.S. Geological Survey Water-Resources Investigations Report 84-4032, 56 p.

Sass, J.H., and Lachenbruch, A.H., 1982, Preliminary interpretation of thermal data from the Nevada Test Site: U.S. Geological Survey Open-File Report 82-973, 30 p.

Sawyer, D.A., Fleck, R.J., Lanphere, M.A., Warren, R.G., Broxton, M.R., 1994, Episodic caldera volcanism in the Miocene southwestern Nevada volcanic field: Revised stratigraphic framework, ${ }^{40} \mathrm{Ar} / 39 \mathrm{Ar}$ geochronology, and implications for magmatism and extension: Geological Society of America Bulletin, v. 106, p. 1304-1418.

Thordarson, William, 1983, Geohydrologic data and test results from well J-13, Nevada Test Site, Nye County, Nevada: U.S. Geological Survey Water-Resources Investigations Report 83-4171, 57 p.

Thordarson, William, and Howells, Lewis, 1987, Hydraulic tests and chemical quality of water at well USW VH-1, Crater Flat, Nye County, Nevada: U.S. Geological Survey Water-Resources Investigations Report 86-4359, 20 p.

Thordarson, William, Rush, F.E., Spengler, R.W., and Waddell, S.J., 1984, Geohydrologic and drill-hole data for test well USW H-3, Yucca Mountain, Nye County, Nevada: U.S. Geological Survey Open-File Report 84-149, 54 p.

Thordarson, William, Rush, F.E., and Waddell, S.J., 1984, Geohydrology of test well USW H-3, Yucca Mountain, Nye County, Nevada: U.S. Geological Survey Water-Resources Investigations Report 84-4272, 38 p.

Tucci, Patrick, O’Brien, G.M., and Burkhardt, D.J., 1996, Water levels in the Yucca Mountain area, Nevada, 1990-91: U.S. Geological Survey Open-File Report 94-111, 107 p.

Tucci, Patrick, Goemaat R.L., and Burkhardt, D.J., 1996, Water levels in the Yucca Mountain area, Nevada, 1993: U.S. Geological Survey Open-File Report 95-159, 94 p.

U.S. Department of Energy, 1988, Site characterization plan, Yucca Mountain site, Nevada research and development area, Nevada: U.S. Department of Energy Report DOE RW/0199, 8 v., various pagination. 
Waddell, R.K., 1982, Two-dimensional, steady-state model of ground-water flow, Nevada Test Site and vicinity, NevadaCalifornia: U.S. Geological Survey Water-Resources Investigations Report 82-4085, 77 p.

Whitfield, M.S., Jr., Eshom, E.P., Thordarson, William, and Schaefer, D.H., 1985, Geohydrology of rocks penetrated by test well USW H-4, Yucca Mountain, Nye County, Nevada: U.S. Geological Survey Water-Resources Investigations Report $85-4030,33 \mathrm{p}$.

Whitfield, M.S., Jr., Thordarson, William, and Eshom, E.P., 1984, Geohydrologic and drill-hole data for test well USW H-4, Yucca Mountain, Nye County, Nevada: U.S. Geological Survey Open-File Report 84-449, 39 p.

Winograd, I.J., and Thordarson, William, 1975, Hydrogeologic and hydrochemical framework, south-central Great Basin, Nevada-California, with special reference to the Nevada Test Site: U.S. Geological Survey Professional Paper 712-C, $126 \mathrm{p}$.

Young, R.A., 1972, Water supply for the Nuclear Rocket Development Station at the U.S. Atomic Energy Commission's Nevada Test Site: U.S. Geological Survey Water-Supply Paper 1938, 19 p. 